\title{
DEVELOPMENT STATUS OF NEAR-ISOTROPIC GRAPHITES FOR LARGE HTGRS
}

\author{
by \\ G. B. ENGLE, R. J. PRICE \\ W. R. JOHNSON, and L. A. BEAVAN
}

Prepared under

Contract AT(04-3)-167

Project Agreement No. 17

for the

San Francisco Operations Office

U.S. Atomic Energy Commission

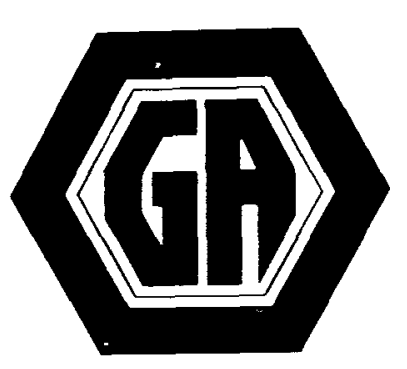

NOTICE

This report was prepared as an account of nork sponsored by the United States Government Neither the United States nor the United States Atomic Energy Commission nor any of ther employees, nor any of thes contractors, subcontractors, or the is employees, makes ans warrants, express or implued, or assumes any

legal labulity or responsibulity for the accuracy, com

pleteness or usefulness of any information, apparatus,

product or process doclosed, or represents that its use

would not infringe privdty ouned rights

\section{GENERAL ATOMIC}

GENERAL ATOMIC COMPANY

P.O. BOX 81608

SAN DIEGO, CALIFORNIA 92138
1

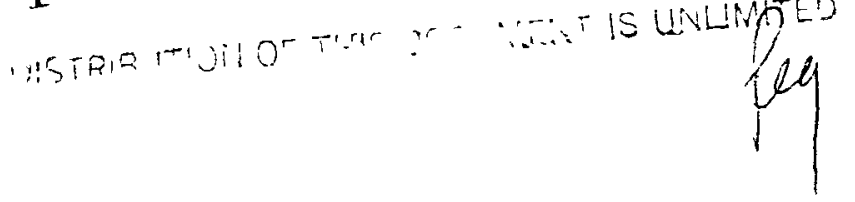




\section{DISCLAIMER}

This report was prepared as an account of work sponsored by an agency of the United States Government. Neither the United States Government nor any agency Thereof, nor any of their employees, makes any warranty, express or implied, or assumes any legal liability or responsibility for the accuracy, completeness, or usefulness of any information, apparatus, product, or process disclosed, or represents that its use would not infringe privately owned rights. Reference herein to any specific commercial product, process, or service by trade name, trademark, manufacturer, or otherwise does not necessarily constitute or imply its endorsement, recommendation, or favoring by the United States Government or any agency thereof. The views and opinions of authors expressed herein do not necessarily state or reflect those of the United States Government or any agency thereof. 


\section{DISCLAIMER}

Portions of this document may be illegible in electronic image products. Images are produced from the best available original document. 


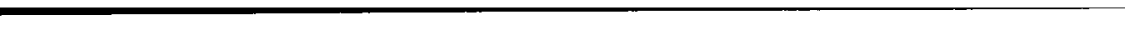

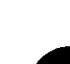

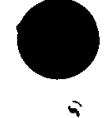

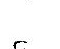

$\checkmark$

r

$\bullet$ 
CONTENTS

1. CONCLUSIONS AND SUMMARY . . . . . . . . . . . . . . . . . 1

1.1. Conclusions . . . . . . . . . . . . . . . . . . . . . . 1

1.2. Summary . . . . . . . . . . . . . . . . . 2

1.2.1. Introduction. . . . . . . . . . . . . 2

1.2.2. Experimental Results............... 3

2. IntROdUCtion. . . . . . . . . . . . . . . . . . . 6

3. REVIEW OF EXPERIENCE WITH NEAR-ISOTROPIC GRAPHITES. . . . . . . 8

3.1. Gilsocoke-Based Graphites . . . . . . . . . . . . . . . . 8

3.1.1. Gilsocoke-Based Graphites for AGRs
in the U.K. . . . . . . . . . . . . . . . 8

3.1.2. Gilsocoke-Based Graphite for HTGRs

3.1.3. Gilsocoke-Based Graphites in the U.S. . . . . . . 19

3.1.4. Assessment of Gilsocoke Graphites . . . . . . . . 19

3.2. Non-Gilsocoke Graphites for HTGRs in Europe . . . . . . . 23

4. MAterials . . . . . . . . . . . . . . . . . . . 24

4.1. Near-Isotropic Graphites. . . . . . . . . . . . . . . 24

4.1.1. Great Lakes Carbon Company - Grades $\mathrm{H}-429$ and $\mathrm{H}-451$. . . . . . . . . . . . . . 26

4.1.2. Union Carbide Corporation, Carbon Products Division - Grade TS-1240. . . . . . . . . . 26

4.1.3. Pechiney Ugine Kuhlman Group - Grade $\mathrm{P}_{3}$ JHAN . . . 27

4.2. Needle-Coke Graphites . . . . . . . . . . . . . . . 27

4.2.1. Great Lakes Carbon Company - Grade H-327. . . . . 27

4.2.2. Union Carbide Corporation, Carbon Products
Division - Grade TS-1111. . . . . . . . 28

4.2.3. AirCo Speer Carbon Company - Grade 9567 . . . . . 28 
5. EXPER IMENTAL METHODS. . . . . . . . . . . . . . . . . . 29

5.1. Capsule $\mathrm{OG}-1$. . . . . . . . . . . . . . . . . . 29

5.2. Dimensional Measurements. . . . . . . . . . 31

5.3. Density . . . . . . . . . . . . . . . . 31

5.4. Tensile Properties. . . . . . . . . . . . . . 31

5.4.1. Stress-Strain Curves. . . . . . . . . . . 31

5.4.2. Tensile Strength. . . . . . . . . . . . 32

5.4.3. Modulus of Elasticity........... . 32

5.4.4. Strain at Fracture. . . . . . . . . . . . 34

5.4.5. Poisson's Ratio.............. 34

5.5. Thermal Conductivity. . . . . . . . . . . . 34

5.6. Thermal Expansivity . . . . . . . . . . . . 35

5.7. Chemical Impurities . . . . . . . . . . . . 35

5.8. Oxidation Rate. . . . . . . . . ..... . . 35

5.9. Cesium Sorption. . . . . . . . . . . . . . . 35

6. EXPERIMENTAL DATA . . . . . . . . . . . . . . . . . . 37

6.1. Properties of Unirradiated Graphites. . . . . . . . . . 37

6.1.1. Bulk Density. . . . . . . . . . . . . 37

6.1.2. Thermal Expansivity. . . . . . . . . 37

6.1.3. Thermal Conductivity. . . . . . . . . . . 38

6.1.4. Mean Values of Thermal Expansivity and Thermal
Conductivity of Graphites......... 38

6.1.5. Tensile Properties. . . . . . . . . . . 38

6.1.6. Impurity Concentrations .. . . . . . . . . 41

6.1.7. Effects of Steam-Graphite Oxidation $\mathrm{H}-451$ and $\mathrm{H}-327$........... . . 41

6.2. Irradiation Behavior. . . . . . . . . . . . . . 46

6.2.1. Dimensional Changes.... . . . . . . . 46

6.2.2. Thermal Expansivity . . . . . . . . . . 58

6.2.3. Thermal Conductivity. . . . . . . . . . . 60

6.2.4. Tensile Properties. . . . . . . . . . . 63

6.2.5. Cesium Sorption.............. 66

7. ACKNOWLEDGMENTS . . . . . . . . . . . . . . . . . 70

REFERENCES. . . . . . . . . . . . . . . . . . . 71

APPENDIX. . . . . . . . . . . . . . . . . . . . . $\mathrm{A}-1$ 


\section{FIGURES}

3-1. Dimensional changes of U.K. isotropic graphites, perpendicular to extrusion or parallel to molding, at DFR temperatures in the range $370^{\circ}$ to $440^{\circ} \mathrm{C}$. . . . . . 9

3-2. Dimensional changes of U.K. isotropic graphites, perpendicular to extrusion, at temperatures of $500^{\circ}$ to $550^{\circ} \mathrm{C}$ and $710^{\circ} \mathrm{C}$ in DFR and $700^{\circ} \mathrm{C}$ in BR-2... . 10

3-3. Fractional changes in dynamic Young's modulus $E$ and tensile strength $\mathrm{S}$ of U.K. isotropic graphites at temperatures of $350^{\circ}$ to $440^{\circ} \mathrm{C}$ in DFR and $700^{\circ} \mathrm{C}$ in $\mathrm{BR}-2$. . . . . . . . . . . . . . . . . . . . . 12

3-4. Dragon Project data on dimensional changes of pressed Gilsocoke graphite No.95. . . . . . . . . . . . . 13

3-5. Dragon Project data on the coefficient of thermal expansion $\left(20^{\circ}\right.$ to $\left.400^{\circ} \mathrm{C}\right)$ of molded Gilsocoke graphite No. 95. . . . . . . . . . . . . . . 15

3-6. Dragon Project data on the fractional changes in Young's modulus of molded Gilsocoke graphite No. 95. . . . 16

3-7. Dragon Project data on the steady-state irradiation creep constant as a function of irradiation temperature. . . . . . . . . . . . . . . . . . .

3-8. Dragon Project data on the bend strength as a function of the static Young's modulus for irradiated graphite. . .

3-9. Dimensional changes as a function of fluence for $\mathrm{H}-328$ graphite at $760^{\circ}, 950^{\circ}$ to $1015^{\circ} \mathrm{C}$, and $1100^{\circ}$ to $1250^{\circ} \mathrm{C}$. . 20

3-10. Thermal conductivity versus fluence at $560^{\circ}$ to $1455^{\circ} \mathrm{C}$ for $\mathrm{H} \neg 328$ graphite (perpendicular) . . . . . . . . . . 21

3-11. Thermal expansivity changes of Gilsocoke graphite measured at $400^{\circ} \mathrm{C}$ as a function of neutron fluence. . . .

5-1. Stress-strain curves for graphite. . . . . . . . . . . . 33

6-1. Temperature dependence of steam-graphite reaction rate data measured at conditions of $2.8 \% \mathrm{H}_{2} \mathrm{O}$ in helium with

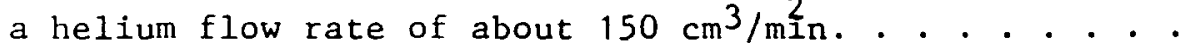

6-2. Temperature dependence of steam-graphite reaction rate data measured at conditions of $2.8 \% \mathrm{H}_{2} \mathrm{O}$ in helium with a helium flow rate of about $100 \mathrm{~cm}^{3} / \mathrm{min}$. . . . . . . .

6-3. Dimensional changes of near-isotropic graphites $\mathrm{H}-451 / \mathrm{H}-429$ in the parallel direction. . . . . . . . . . .

6-4. Dimensional changes of near-isotropic graphites $\mathrm{H}-451 / \mathrm{H}-429$ in the perpendicular direction . . . . . . .

6-5. Comparison of dimensional changes of $\mathrm{H}-327$ and $\mathrm{H}-451 / \mathrm{H}-429$. 


\section{FIGURES (continued)}

6-6. Thermal expansivity of $\mathrm{H}-327$ graphite as a function of fast neutron fluence at $875^{\circ}$ to $975^{\circ} \mathrm{C}$ and $575^{\circ}$ to $650^{\circ} \mathrm{C}$. . . . . . . . . . . . . . . . 59

6-7. Thermal expansivity of $\mathrm{H}-451 / \mathrm{H}-429$ graphites as a function of fast neutron fluence at $1370^{\circ}$ to $1500^{\circ} \mathrm{C}$ and $1050^{\circ}$ to $1275^{\circ} \mathrm{C}$. . . . . . . . . . . . .

6-8. Thermal expansivity of $\mathrm{H}-451 / \mathrm{H}-429$ graphites as a function of fast neutron fluence at $900^{\circ}$ to $975^{\circ} \mathrm{C}$, $850^{\circ} \mathrm{C}$, and $650^{\circ} \mathrm{C}$. . . . . . . . . . . . .

6-9. Calculated curves of the thermal conductivity of $\mathrm{H}-451$ graphite at the irradiation temperature as a function of irradiation temperature. . . . . . . . . . . 64

6-10. Typical stress-strain curves for unirradiated and irradiated $\mathrm{H}-451$ graphite. . . . . . . . . . . . 65

6-11. Change in ultimate tensile strength and Young's modulus as a function of fluence, $\mathrm{H}-327$ graphite, $640^{\circ}$ to $700^{\circ} \mathrm{C}$ and $770^{\circ}$ to $900^{\circ} \mathrm{C}$. . . . . . . . . . .

6-12. Change in ultimate tensile strength and Young's modulus as a function of fluence, $\mathrm{H}-327$ graphite, $960^{\circ}$ to

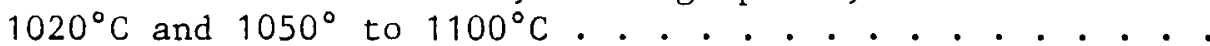

6-13. Change in ultimate tensile strength and Young's modulus as a function of fluence, $\mathrm{H}-451$ graphite, $580^{\circ}$ to $630^{\circ} \mathrm{C}, 900^{\circ}$ to $950^{\circ} \mathrm{C}$, and $1340^{\circ}$ to $1370^{\circ} \mathrm{C}$. . . . . .

TABLES

1-1. Summary comparison of properties and irradiation behavior of graphites $\mathrm{H}-451$ and $\mathrm{H}-327$. . . . . . . . . . . . . . . 4

4-1. Description of near-isotropic and H-327 graphites. . . . . . 25

5-1. Mean temperatures and fluences in capsule OG-1 . . . . . . 30

6-1. Mean values of thermal properties of candidate graphites . . 39

6-2. Average tensile properties of $\mathrm{H}-451$ and $\mathrm{H}-327$ graphite samples. . . . . . . . . . . . . . . . . 40

6-3. Poisson's ratio for grade H-451 graphite......... . 42

6-4. Comparison of mean irradiation-induced dimensional changes in $\mathrm{H}-327$ and $\mathrm{H}-451$ graphites irradiated in OG-1................ . . 57 
A-1. Bulk densities of H-451 graphite . . . . . . . . . . . . A-2

A-2. Bulk densities of TS-1240 graphite . . . . . . . . . . . . . A-4

A-3. Thermal expansivity of $\mathrm{H}-451$ graphite. . . . . . . . . . . . A-6

A-4. Thermal expansivity of H-429 graphite. . . . . . . . . . . . A-7

A-5. Thermal expansivity of $\mathrm{P}_{3}$ JHAN graphite. . . . . . . . . . . A-7

A-6. Thermal expansivity of $\mathrm{H}-327$ graphite. . . . . . . . . . . . A-8

A-7. Thermal conductivity of $\mathrm{H}-451$ graphite . . . . . . . . . . . A-9

A-8. Thermal conductivity of TS-1240 graphite . . . . . . . . . A-10

A-9. Thermal conductivity of $\mathrm{H}-327$ graphite . . . . . . . . . . A-11

A-10. Tensile properties of H-451 graphite (0.505-in.-diameter x 4-in.-long samples)................ . A-12

A-11. Tensile properties of H-451 graphite (0.25-in.-diameter x 0.9-in.-long samples) ............. . A-14

A-12. Tensile properties of Fort St. Vrain production logs of H-327 graphite. . . . . . . . . . . . . . . . . A-15

$\mathrm{A}-13$. Chemical impurities in $\mathrm{H}-451$ graphite. . . . . . . . . . . . A-16

A-14. Chemical impurities in TS-1240 graphite. . . . . . . . . . . A-17

A-15. Chemical impurities in $\mathrm{P}_{3}$ JHAN graphite. . . . . . . . . . . A-18

A-16. Dimensional changes of needle-coke $\mathrm{H}-327$ graphite
from capsule OG-1 axial (parallel) orientation . . . . A-19

A-17. Dimensional changes of needle-coke $H-327$ graphite from capsule OG-1 radial (perpendicular) orientation . . . A-24

A-18. Thermal expansivity of $\mathrm{H}-327$ graphite specimens irradiated in capsule $\mathrm{OG}-1$. . . . . . . . . . . . . . . A-27

A-19. Thermal expansivity of $\mathrm{H}-429$ and $\mathrm{H}-451$ graphite specimens irradiated in capsule $\mathrm{OG}-1$. . . . . . . . . . . . . . . . A-28

A-20. Thermal conductivity of $\mathrm{H}-327$ graphite specimens irradiated in capsule $\mathrm{OG}-1$. . . . . . . . . . . . . . . A-29

A-21. Thermal conductivity of $\mathrm{H}-451$ graphite specimens irradiated in capsule $\mathrm{OG}-1$. . . . . . . . . . . . . A-30

A-22. Mean thermal conductivity of graphite specimens
irradiated in capsule OG-1 . . . . . . . . . . . . A-31

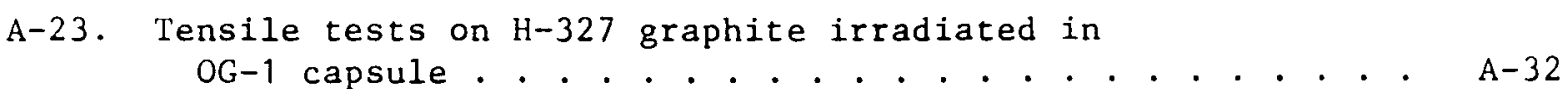

A-24. Tensile tests on H-451 graphite irradiated in OG-1 capsule. . . . . . . . . . . . . . . . . . $\mathrm{A}-34$ 


\section{CONCLUSIONS AND SUMMARY}

\subsection{CONCLUSIONS}

Several new near-isotropic graphites have been developed and evaluated for use as core components in large HTGRs. Although the characterization data and design calculations are still continuing, the available information is sufficient to establish a position regarding the use of near-isotropic graphites in large HTGRs.

The information given in this report on the physical, thermal, and mechanical properties and the irradiation behavior of the near-isotropic graphites, as typified by grade $\mathrm{H}-451$, shows that near-isotropic graphites have excellent potential to fulfill all requirements of large HTGR core design. Further testing to full HTGR lifetime exposures is expected to confirm this premise. The current results show grade $H-451$ to be equal or superior to the current reference needle-coke graphite, grade $\mathrm{H}-327$, in all relevant properties except thermal expansivity. However, the thermal expansivities of near-isotropic graphites are satisfactory to meet the HTGR design requirements.

The stress and differential strain analyses showed the near-isotropic graphites ( $\mathrm{H}-451$ used as an example) to be satisfactory in all aspects (Ref. 1). The near-isotropic graphites also appear to be satisfactory with respect to bowing of fuel and reflector elements. All factors considered, the stress calculations indicate near-isotropic graphites will improve the graphite performance and increase structural design margins. 
Based on the data presented in this report and the calculations presented in Ref. 1, it is concluded that near-isotropic graphites of the type described above will provide a reference graphite that will be satisfactory for current HTGR core designs and will provide additional margins for increasing core graphite fluences and temperatures if necessary for future designs.

\subsection{SURMARY}

\subsubsection{Introduction}

The data for the near-isotropic graphites are compared herein with those of the anisotropic reference grade $\mathrm{H}-327$. These comparisons show the relative merits of the two different graphite types.

Near-isotropic graphites have been under development during the past 3 years for use as core components in large HTGRs. Two candidate graphite grades, using isotropic petroleum coke as a filler in place of the needlecoke filler used in the current reference grade $\mathrm{H}-327$, have been developed by Great Lakes Carbon Company and Union Carbide Corporation. Ful1production-size experimental logs have been evaluated.

The bulk of the data in this report was obtained on Great Lakes Carbon Company grade $\mathrm{H}-451$, or its prototype grade $\mathrm{H}-429$. A lesser amount of data was obtained on Union Carbide Corporation grade TS- 1240 because of the late delivery of the latter grade.

When irradiated to high temperatures and fluences the reference needle-coke graphite grade $\mathrm{H}-327$, which is more anisotropic than grades $\mathrm{H}-451$ or TS-1240, exhibits early expansion in the radial (perpendicular) direction and a relatively large axial (paralle1) contraction. These characteristics limit the flexibility of design for large HTGRs or 
optimization of advanced designs such as process heat or direct cycle gas turbine plants if a needle-coke-based graphite is used.

\subsubsection{Experimental Results}

Grades $H-451$ and TS -1240 were characterized by measuring (1) bulk density, (2) thermal expansivity, (3) thermal conductivity, (4) tensile properties including ultimate strength, strain at fracture, Young's modulus of elasticity, and Poisson's ratio, (5) impurity concentrations, and (6) oxidation rate on unirradiated specimens. The irradiation behavior of grade H-451 was assessed by measuring the changes in (1) dimensions, (2) thermal expansivity, (3) thermal conductivity, and (4) tensile properties as a function of temperature and fast fluence. The data for grade $\mathrm{H}-451$ are summarized in Table 1-1 along with comparative data for H-327. Grade H-451 was found to be dimensionally more stable under irradiation than $\mathrm{H}-327$. At $1150^{\circ} \mathrm{C}$ and $8 \times 10^{21} \mathrm{n} / \mathrm{cm}^{2}$, grade $\mathrm{H}-327$ shows net expansion in the radial direction whereas $\mathrm{H}-451$ does not. The rate of contraction for $\mathrm{H}-327$ in the axial direction is approximately 2.5 higher than that for H-451. The maximum contraction of $\mathrm{H}-451$ in the radial direction does not exceed about $2 \%$, and net expansion is not anticipated until exposures well beyond the range of large HTGR designs. Increased dimensional stability is desirable because it reduces distortions and stresses within the fuel elements.

The strength and Young's modulus of H-451 increase in both orientations after irradiation. The fractional increase in Young's modulus and axial strength for $\mathrm{H}-327$ is similar to that of $\mathrm{H}-451$, but the radial strength of $\mathrm{H}-327$ showed no increase with irradiation.

The irradiated thermal conductivity values in the radial direction for $\mathrm{H}-451$ (the direction of heat flow) are 10 to $50 \%$ higher than those for $\mathrm{H}-327$. 
TABLE 1-1

SUMMARY COMPARISON OF PROPERTIES AND IRRADIATION BEHAVIOR OF GRAPHITES H-451 ANU H-327

\begin{tabular}{|c|c|c|c|c|c|c|}
\hline \multirow[b]{3}{*}{ Property } & \multicolumn{2}{|c|}{ Irradiation Conditions } & \multicolumn{4}{|c|}{ Property Value } \\
\hline & \multirow{2}{*}{$\begin{array}{c}\text { Temperature } \\
\left({ }^{\circ} \mathrm{C}\right)\end{array}$} & \multirow{2}{*}{$\begin{array}{l}\text { Fast F luence } \\
\times 10^{-21}\left(\mathrm{n} / \mathrm{cm}^{2}\right) \\
(\mathrm{E}>0.18 \mathrm{MeV})\end{array}$} & \multicolumn{2}{|c|}{ Axial } & \multicolumn{2}{|c|}{ Radial } \\
\hline & & & $\mathrm{H}-451$ & $\mathrm{H}-327$ & $\mathrm{H}-451$ & $\mathrm{H}-327$ \\
\hline Mean density, $\mathrm{g} / \mathrm{cm}^{3}$ & & 0 & $1.74^{(a)}$ & $1.76^{(a)}$ & - & - \\
\hline $\begin{array}{l}\text { Mean thermal expansivity } \times 10^{6} \\
{ }^{\circ} \mathrm{C}^{-1}\left(22^{\circ}-500^{\circ} \mathrm{C}\right)\end{array}$ & & 0 & 3.55 & 1.60 & 4.55 & 3.35 \\
\hline $\begin{array}{l}\text { Thermal conductivity at } \\
\text { irradiation temperature, } \\
\text { cal } / \mathrm{cm}-\sec -{ }^{\circ} \mathrm{C}\end{array}$ & $\begin{array}{c}800 \\
600-625 \\
875-920 \\
1225-1350\end{array}$ & $\begin{array}{c}0 \\
2.2-2.9 \\
3.1-5.1 \\
3.6-9.9\end{array}$ & $\begin{array}{l}0.174 \\
0.080 \\
0.094 \\
0.10\end{array}$ & $\begin{array}{l}0.194 \\
0.067 \\
0.078 \\
0.10\end{array}$ & $\begin{array}{l}0.158 \\
0.079 \\
0.084 \\
0.09\end{array}$ & $\begin{array}{l}0.140 \\
0.043 \\
0.063 \\
0.08\end{array}$ \\
\hline $\begin{array}{l}\text { Ultimate tensile strength, psi } \\
\text { End center } \\
\text { Midlength center } \\
\text { Midlength edge } \\
\text { Midlength center }\end{array}$ & $\begin{array}{c}- \\
- \\
- \\
860-1020\end{array}$ & $\begin{array}{c}0 \\
0 \\
0 \\
2.6-3.4\end{array}$ & $\begin{array}{l}1657 \\
1564 \\
2246 \\
2371\end{array}$ & $\begin{array}{l}2180 \\
1630 \\
2395 \\
2127\end{array}$ & $\begin{array}{l}2051 \\
1671 \\
1637 \\
2648\end{array}$ & $\begin{array}{r}1350 \\
925 \\
1295 \\
962\end{array}$ \\
\hline $\begin{array}{l}\text { Young's modulus, } 10^{6} \text { psi } \\
\text { End center } \\
\text { Midlength center } \\
\text { Midlength edge } \\
\text { Midlength center }\end{array}$ & $\begin{array}{l}- \\
- \\
- \\
860-1020\end{array}$ & $\begin{array}{c}0 \\
0 \\
0 \\
2.6-3.4\end{array}$ & $\begin{array}{l}1.22 \\
1.14 \\
1.28 \\
2.06\end{array}$ & $\begin{array}{l}1.51 \\
1.54 \\
1.75 \\
3.02\end{array}$ & $\begin{array}{l}0.96 \\
1.00 \\
0.94 \\
1.88\end{array}$ & $\begin{array}{l}0.69 \\
0.58 \\
0.65 \\
1.23\end{array}$ \\
\hline Dimensional change, $\%$ & $\begin{array}{r}850 \\
1150 \\
1150\end{array}$ & $\begin{array}{c}4 \\
6.5 \\
8\end{array}$ & $\begin{array}{l}-0.6 \\
-1.8 \\
-2.2(b)\end{array}$ & $\begin{array}{l}-1.3 \\
-4.7 \\
-6.2\end{array}$ & $\begin{array}{l}-0.3 \\
-1.3 \\
-1.5(b)\end{array}$ & $\begin{array}{l}-0.5 \\
-0.1(c) \\
+1.0\end{array}$ \\
\hline $\begin{array}{l}\text { Oxidation rate in } 3 \% \text { steam- } \\
\text { helium mixture, } \% / \text { hr at } 5 \% \\
\text { burnoff at } 1000^{\circ} \mathrm{C}\end{array}$ & - & 0 & $0.27^{(a)}$ & $0.25^{(a)}$ & - & - \\
\hline
\end{tabular}

(a) Orientation heading does not apply.

(b) Extrapolated from $6.5 \times 10^{21} \mathrm{n} / \mathrm{cm}^{2}$.

(c) Specimen expanding. 
The resistance to steam oxidation is approximately equal in the two materials.

The thermal expansivity values of $\mathrm{H}-327$ are lower than those for $\mathrm{H}-451$ and show more anisotropy. 


\section{INTRODUCTION}

The design of large HTGRs requires an efficient moderator and reflector material capable of withstanding high temperatures and high fast fluences. Commercial synthetic graphite has been the material choice for the HTGR core graphite because it is an excellent moderator, has refractory properties, can be manufactured and machined in a wide variety of shapes and sizes, and is relatively low in cost.

The hexagonal fuel and reflector blocks for Fort St. Vrain were manufactured by extrusion with, petroleum needle, coke by conventional manufacturing processes. The core graphite components were extruded as 18.0-in.diameter by 34-in.-long logs, processed to graphite, and subsequently machined into hexagonal blocks that contain a series of fuel and coolant holes. The anisotropic needle-coke particles are highly aligned during the extrusion process, resulting in a material that exhibits high anisotropy in its properties and irradiation dimensional changes. This anisotropy is responsible for large axial contractions and an initial radial contraction followed by rapid radial expansion in the graphite block when irradiated at high temperatures and to fluences of large HTGRs. The anisotropic behavior of the extruded needle-coke graphites limits their allowable incore life.

During the 1960s near-isotropic graphites based on Gilsocoke and other raw materials were developed and evaluated in the U.K. for Advanced GasCooled Reactors (AGRs). These materials and the subsequent data resulting from an extensive evaluation program have been extremely helpful in evaluating near-isotropic graphite data for large HTGRs. Unfortunately Gilsocoke has certain disadvantages as a raw material for nuclear graphite production, and other sources were sought by manufacturers in Europe 
and the U.S. A more complete review and discussion of Gilsocoke graphites is given in Section 3 .

During the past several years, development of nuclear graphites for core components in the U.S. and Europe has been directed toward nearisotropic graphites utilizing raw materials with more assured sources of supply than Gilsocoke. The approach to developing these materials has been to retain conventional manufacturing processes while substituting coke particles with a more isotropic microstructure for needle coke. In Europe cokes derived from coal-tar pitch have been used, whereas in the U.S. nearisotropic cokes derived from petroleum feedstocks were the choice. The development of the near-isotropic materials has progressed to the point where full-production-size logs are available for experimental measurements.

This report describes the status of development of near-isotropic graphites and contains data obtained on several grades plus additional data on the Fort St. Vrain needle-coke graphite H-327. The feasibility of using near-isotropic graphites for large HTGR core components is discussed. 


\section{REVIEW OF EXPERIENCE WITH NEAR-ISOTROPIC GRAPHITES}

\subsection{GILSOCOKE-BASED GRAPHITES}

\subsubsection{Gilsocoke-Based Graphites for AGRs in the U.K.}

In the early 1960s the UKAEA was developing AGRs utilizing a fixed graphite moderator structure, $\mathrm{CO}_{2}$ cooling, and a maximum graphite temperature of $550^{\circ} \mathrm{C}$. Compared with the anisotropic PGA graphite previously employed in the U.K. Magnox reactors, this required a graphite with improved dimensional stability (because of the higher total neutron fluences) and better resistance to radiolytic oxidation by $\mathrm{CO}_{2}$. A specification for the new graphite was written (Ref. 2) which, among other requirements, called for a coefficient of thermal expansion (measured between $20^{\circ}$ and $120^{\circ} \mathrm{C}$ ) of at least $5 \times 10^{-6}{ }^{\circ} \mathrm{C}^{-1}$ in both directions and an open pore volume limit of $6.5 \mathrm{~cm}^{3} / 100 \mathrm{~g}$. The high thermal expansivity was specified because analyses of graphite behavior indicated this would minimize irradiation-induced dimensional change at the temperature of interest. Candidate graphites, extruded using Gilsocoke filler, were submitted by Anglo Great Lakes, Ltd., and British Acheson Electrodes, Ltd., and were eventually qualified.

Irradiation testing of these materials and similar materials made from coal-tar pitch coke and an undisclosed coke type was conducted at temperatures between $370^{\circ}$ and $710^{\circ} \mathrm{C}$ in the Dounreay Fast Reactor (Scotland) and the Belgian BR-2 reactor. The results are summarized in Ref. 3. Examples of the dimensional change versus fluence curves are shown in Figs. 3-1 and 3-2. All the graphites contracted initially in both directions, with 


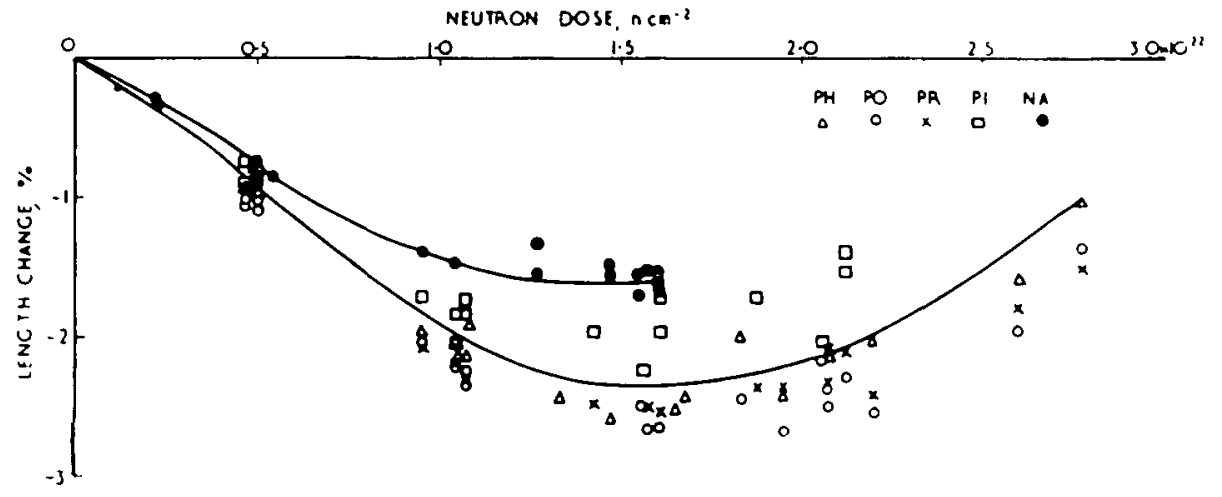

Fig. 3-1. Dimensional changes of U.K. isotropic graphites, perpendicular to extrusion or parallel to molding, at DFR temperatures in the range $370^{\circ}$ to $440^{\circ} \mathrm{C}$. NA is molded grade; others are extruded. (Neutron dose in NDE units. The conversion factor is NDE units $\times 1.7=\mathrm{E}>0.18$ $\mathrm{MeV}$ units.) (From Ref. 3.) 


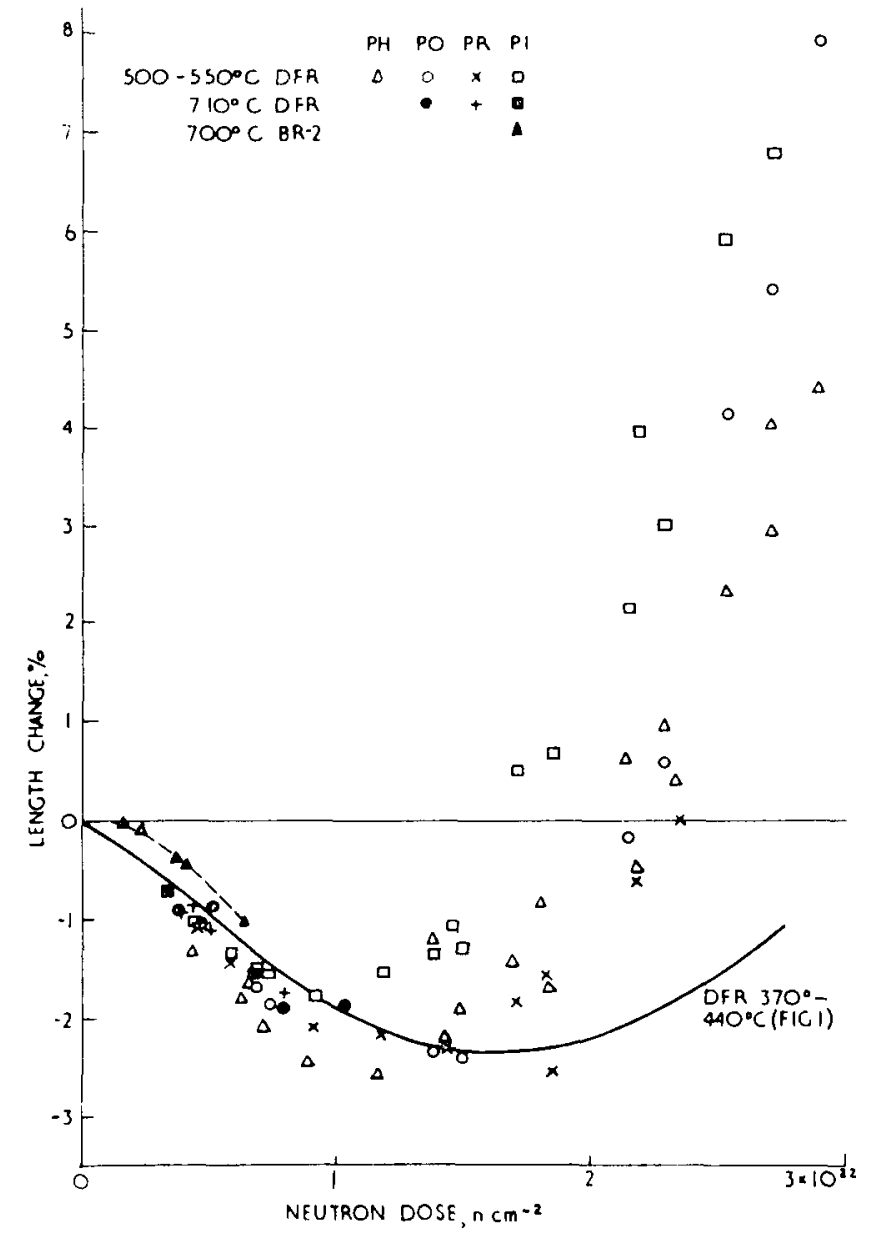

Fig. 3-2. Dimensional changes of U.K. isotropic graphites, perpendicular to extrusion, at temperatures of $500^{\circ}$ to $550^{\circ} \mathrm{C}$ and $710^{\circ} \mathrm{C}$ in $\mathrm{DFR}$ and $700^{\circ} \mathrm{C}$ in $\mathrm{BR}-2$. (Neutron dose in NDE units. The conversion factor is NDE units $\times 1.7=\mathrm{E}>0.18 \mathrm{MeV}$ units.)

(From Ref. 3.) 
the contraction rates being somewhat lower in molded grades than in the extruded materials. At about $2.5 \times 10^{22} \mathrm{n} / \mathrm{cm}^{2}(E>0.18 \mathrm{MeV}$ ) contraction stopped and expansion started. The expansion was more rapid at $500^{\circ}$ to $550^{\circ} \mathrm{C}$ than at $370^{\circ}$ to $440^{\circ} \mathrm{C}$, and the data points became more scattered after the samples expanded past their original dimensions at $500^{\circ}$ to $550^{\circ} \mathrm{C}$. Fractional changes in Young's modulus and strength are shown in Fig. 3-3. Young's modulus increased more rapidly with fluence than did the tensile strength. A reduction in strength and thermal conductivity due to radiolytic oxidation by $\mathrm{CO}_{2}$ was also reported. Monitoring of the dimensions and properties of near-isotropic graphite components in U.K. reactors is carried on continuously (Refs. 4, 5). So far the graphite has performed predictably and its behavior has been consistent with the data from capsule irradiations.

3.1.2. Gilsocoke-Based Graphite for HTGRs in the U.K.

During 1965 through 1968 the successful operation of the Dragon reactor and the AVR pebble-bed reactor caused increased interest in high-temperature gas-cooled reactors in Europe, and design work for commercial HTGRs was undertaken. Because the Gilsocoke-based graphites developed for the AGR program were available as production materials and had demonstrated good dimensional stability and strength at irradiation temperatures up to $700^{\circ} \mathrm{C}$, it was decided that the initial reference material for the HTGR moderator and fuel tubes and the pebble-bed reactor reflector blocks should be Gilsocoke-based graphite. An extensive testing program on Europeanmanufactured Gilsocoke-based graphites was started, employing test facilities in the HFR (Petten) and the Dragon reactor and using test temperatures up to $1400^{\circ} \mathrm{C}$.

Dragon Project irradiation test data on Gilsocoke graphites are included in Refs. 6 through 10. Figure 3-4 shows an example of the dimensional change behavior of a molded production-quality Gilsocoke graphite (Dragon Reference No. 95). The general behavior pattein resembles that established for lower irradiation temperatures by UKAEA workers, except 


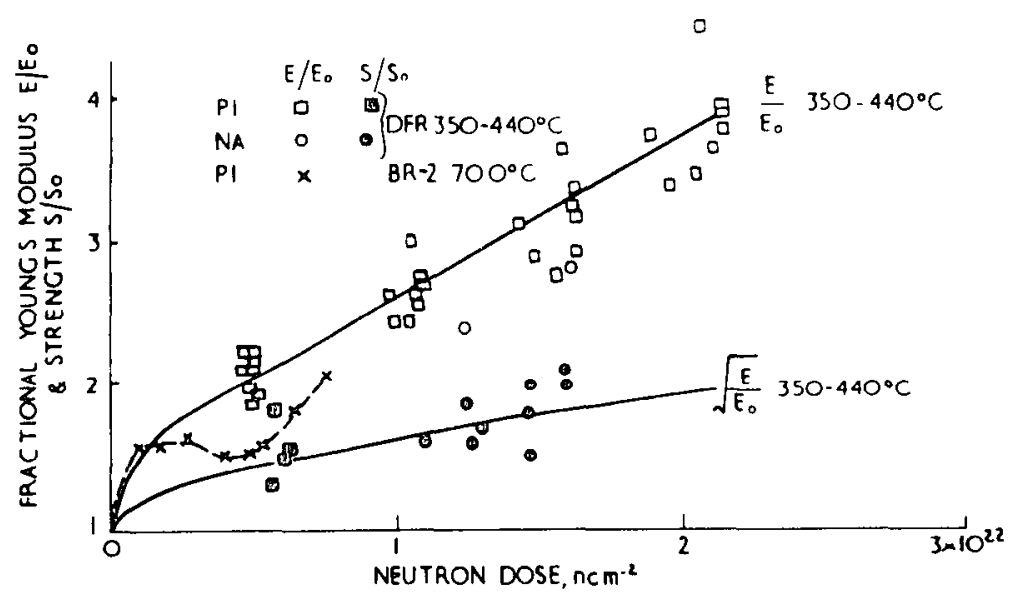

F1g. 3-3. Fractional changes in dynamic Young's modulus E and tensile strength $\mathrm{S}$ of U.K. isotropic graphites at temperatures of $350^{\circ}$ to $440^{\circ} \mathrm{C}$ in $\mathrm{DFR}$ and $700^{\circ} \mathrm{C}$ in BR-2. (Neutron dose in NDE units. The conversion factor is NDE units $\times 1.7=\mathrm{E}>0.18 \mathrm{MeV}$ units.) (From Ref. 3.) 


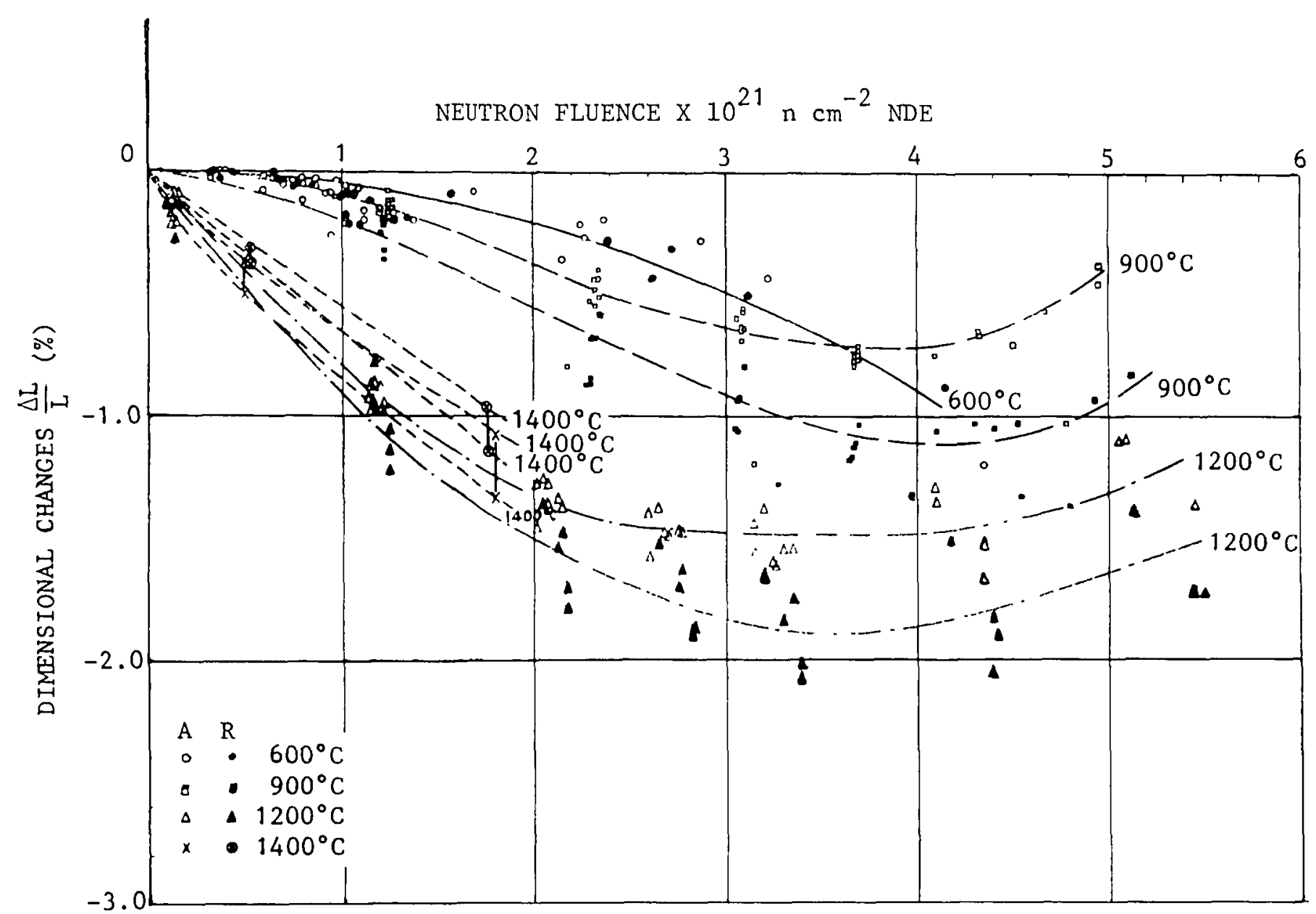

Fig. 3-4. Dragon Profect data on dimensional changes of pressed Gilsocoke graphite No. 95. (NDE unfts $\times 1.7=\mathrm{E}>0.18 \mathrm{MeV}$ units.) (From Ref. 8.) 
that the change rates are accelerated for irradiation temperatures up to $1200^{\circ} \mathrm{C}$. The point of "turnaround" in sample dimensions is 5.0 to $7.0 \mathrm{x}$ $10^{21} \mathrm{n} / \mathrm{cm}^{2}$ ( $\mathrm{E}>0.18 \mathrm{MeV}$ ) for irradiation temperatures of both $900^{\circ}$ and $1200^{\circ} \mathrm{C}$, but the maximum linear shrinkage is only about $1 \%$ at $900^{\circ} \mathrm{C}$ compared with 1.5 to $2 \%$ at $1200^{\circ} \mathrm{C}$. Results for extruded Gilsocoke grades were generally similar except that differences between the parallel and perpendicular directions were more pronounced.

Changes in the thermal expansivity and Young's modulus of the same grade are shown in Figs. $3-5$ and 3-6. After a small initial increase in thermal expansivity, further irradiation at $900^{\circ}$ and $1200^{\circ} \mathrm{C}$ reduces the thermal expansivity to less than half its original value. Irradiation first increases Young's modulus by 20 to $60 \%$ (depending on the temperature) and then, after a plateau, a second increase during irradiation at $900^{\circ}$ or $1200^{\circ} \mathrm{C}$ carries the Young's modulus to a peak value about 2.5 times its original level.

Irradiation creep measurements, using self-straining tensile assemblies, yielded scattered data (Fig. 3-7). Values for the steady-state creep constant of Gilsocoke grades increased from 1 to $2 \times 10^{-27}(\mathrm{psi})^{-1}\left(\mathrm{n} / \mathrm{cm}^{2}\right)^{-1}$ at $600^{\circ} \mathrm{C}$ to 3 to $6 \times 10^{-27}$ (psi) $)^{-1}\left(\mathrm{n} / \mathrm{cm}^{2}\right)^{-1}$ at $1200^{\circ} \mathrm{C}$.

A careful postirradiation analysis, including dimensional and residual stress measurements, was made of the inner and outer fuel tube of an experimental Dragon fuel element (FE 923) (Ref. 8). The graphite was an extruded Gilsocoke-grade graphite and the peak fluence was $1.7 \times 10^{21} \mathrm{n} / \mathrm{cm}^{2}$ (E>0.18 $\mathrm{MeV}$ ). Operating temperatures fell between $900^{\circ}$ and $1100^{\circ} \mathrm{C}$. Both the measured shrinkages and the residual stresses agreed well with calculations based on material property data from samples in irradiation capsules.

Strength measurements on near-isotropic graphite samples from this and other Dragon reactor tests (Ref. 11) showed an increase in strength paralleling the increase in dynamic elastic modulus. The relationship is shown in Fig. 3-8. 


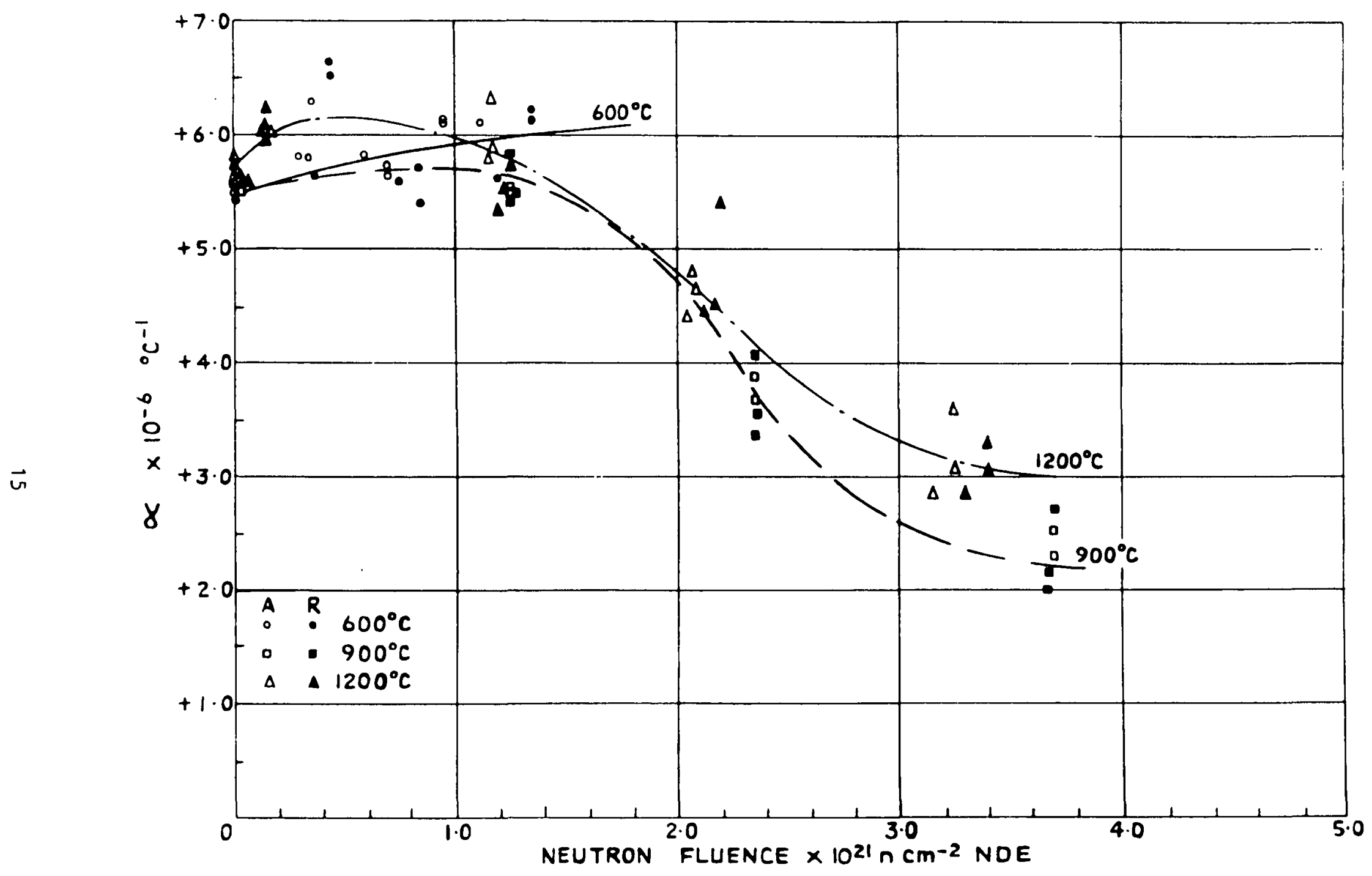

Fig. 3-5. Dragon Profect data on the coefficient of thermal expansion $\left(20^{\circ}\right.$ to $\left.400^{\circ} \mathrm{C}\right)$ of molded Gilsocoke graphite No. 95. (NDE units $\times 1.7=\mathrm{E}>0.18 \mathrm{MeV}$ units.) (From Ref. 8.) 


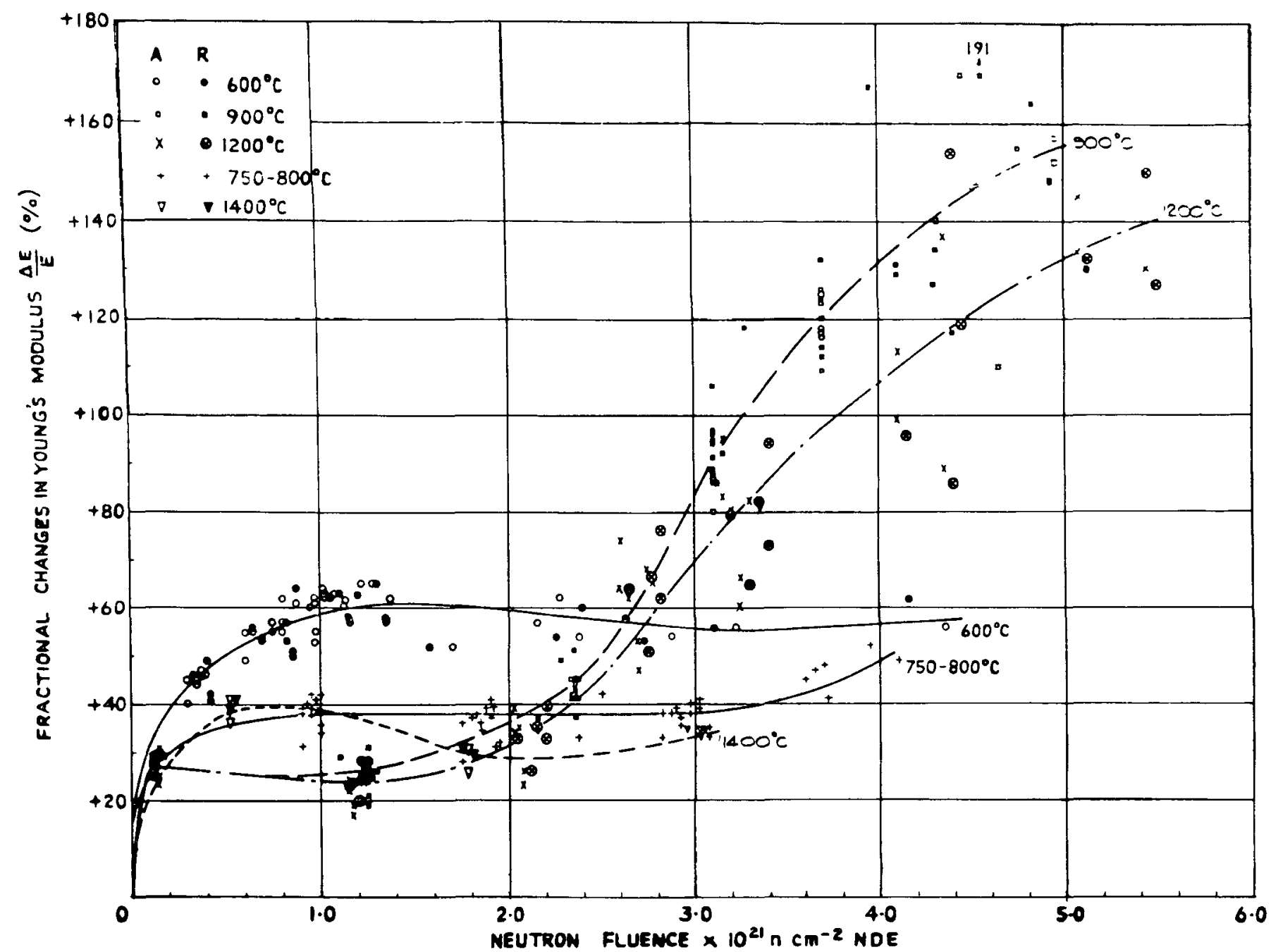

Fig. 3-6. Dragon Profect data on the fractional changes in Young's modulus of molded Gilsocoke graphite No. 95. (NDE units $\times 1.7=\mathrm{E}>0.18 \mathrm{MeV}$ units.) (From Ref. 8.) 


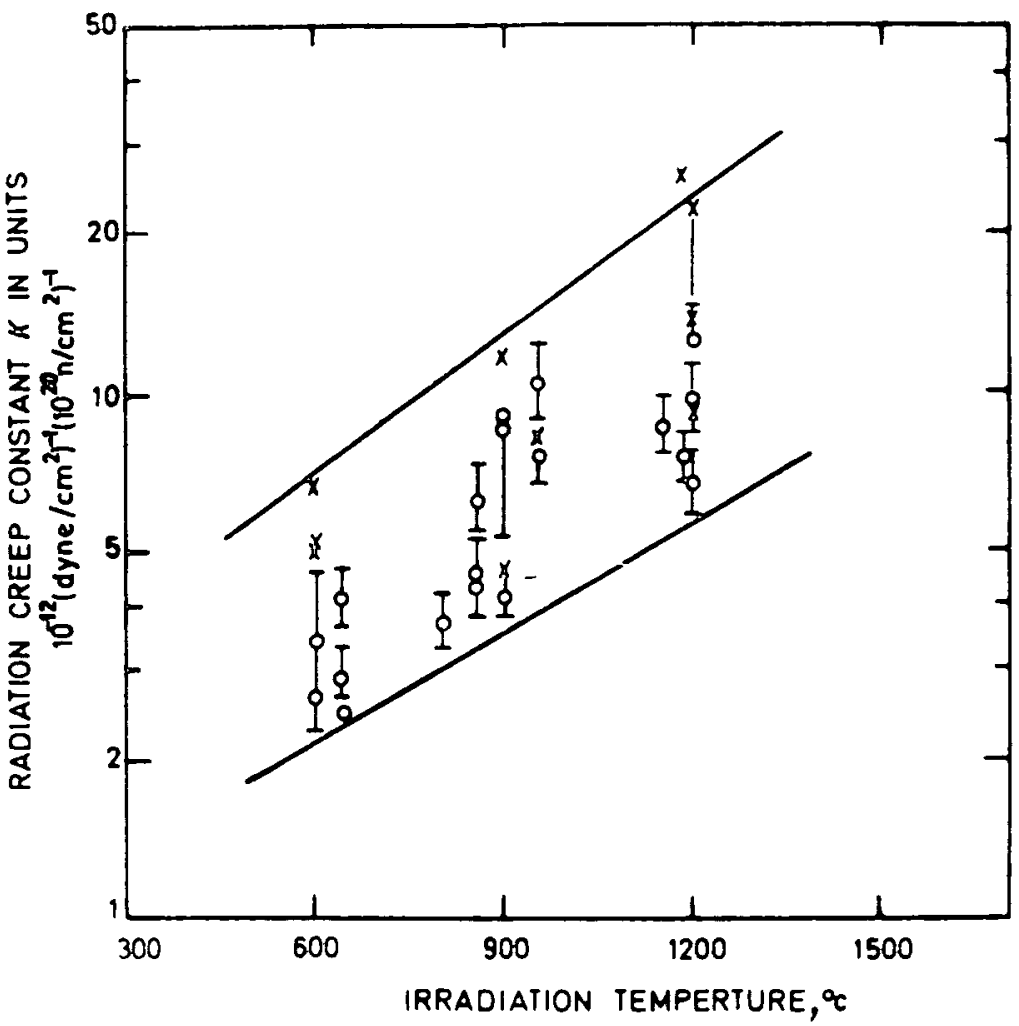

Fig. 3-7. Dragon Profect data on the steady-state irradiation creep constant as a function of 1rradiation temperature. (0 - Gilsocoke graphites; X - other reactor graph1tes.) (From.Ref. 7.) 


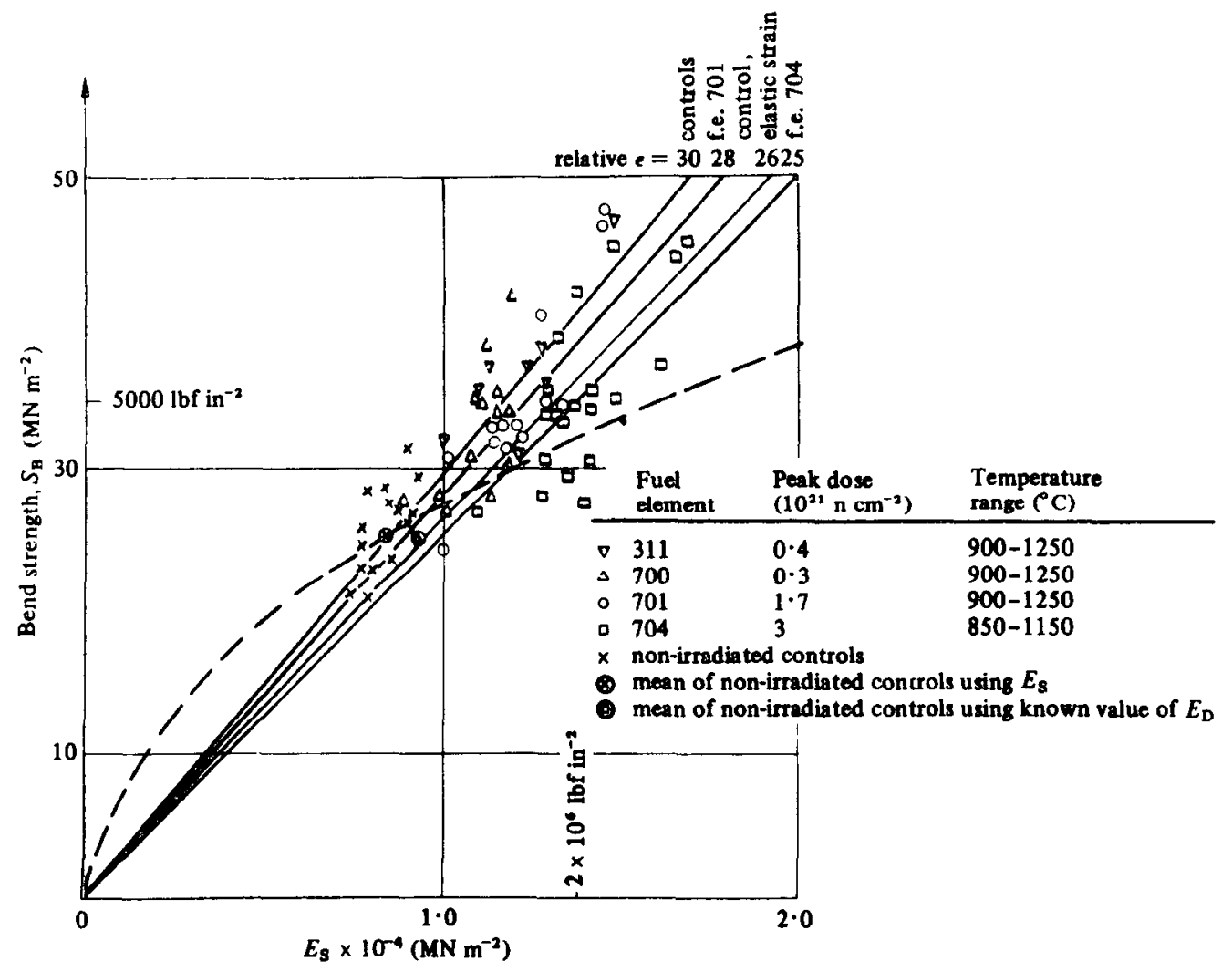

Fig. 3-8. Dragon Profect data on the bend strength as a function of the static Young's modulus for irradiated graphite. (From Ref. 11.) 


\subsubsection{Gilsocoke-Based Graphites in the U.S.}

Gilsocoke graphites were never considered as candidate materials for HTGRs in the U.S., but due to the interest shown in the U.K. and their excellent irradiation stability some attention was given to their evaluation. Gilsocoke graphites supplied by the Great Lakes Carbon Company, U.S., were evaluated at General Atomic Company (GAC) and Battelle Northwest Laboratories (BNWL). Dimensional (Ref. 12) and thermal conductivity (Ref. 13) changes as a function of irradiation temperature and fluence are shown in Figs. 3-9 and 3-10. Thermal expansivity (Ref. 14) changes are shown in Fig. 3-11. The U.S. and U.K. data for Gilsocoke graphites were in good agreement.

\subsubsection{Assessment of Gilsocoke Graphites}

Gllsocoke graphites proved to be more than satisfactory for advanced AGRs and also showed promise for design of U.S. and European HTGRs. However, it was realized their use had several disadvantages, i.e.:

1. High processing costs.

2. A single raw material source (the American Gilsonfte Company in the U.S.).

3. A combination of high thermal expansivity and high elastic modulus, which creates relatively high shutdown stresses in components that operate with a steep temperature gradient.

4. Poor machinability especially with respect to cost due to high tool wear.

Thus, while the irradiation stability of the Gilsocoke graphites was superior to the anisotropic materials and desirable, the above mentioned liablities prevented the acceptance of Gilsocoke graphites for HTGR 


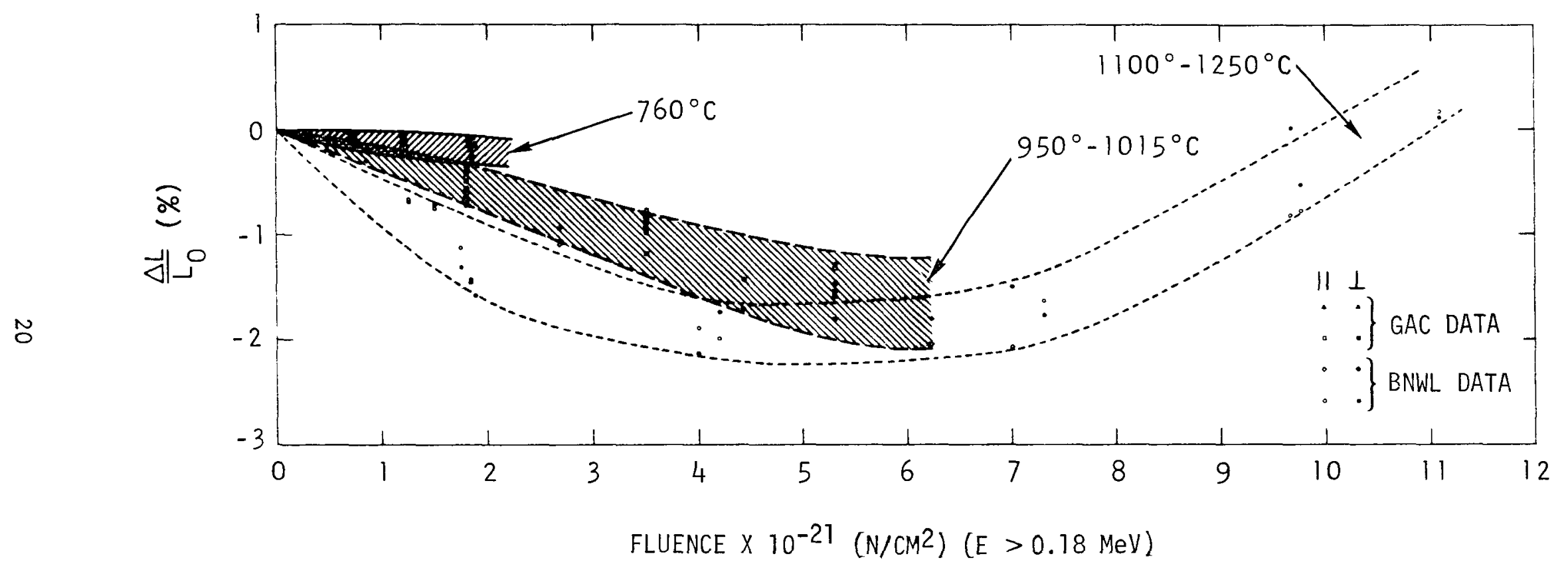

Fig. 3-9. Dimensional changes as a function of fluence for H-328 graphite at $760^{\circ}, 950^{\circ}$ to $1015^{\circ} \mathrm{C}$, and $1100^{\circ}$ to $1250^{\circ} \mathrm{C}$ 


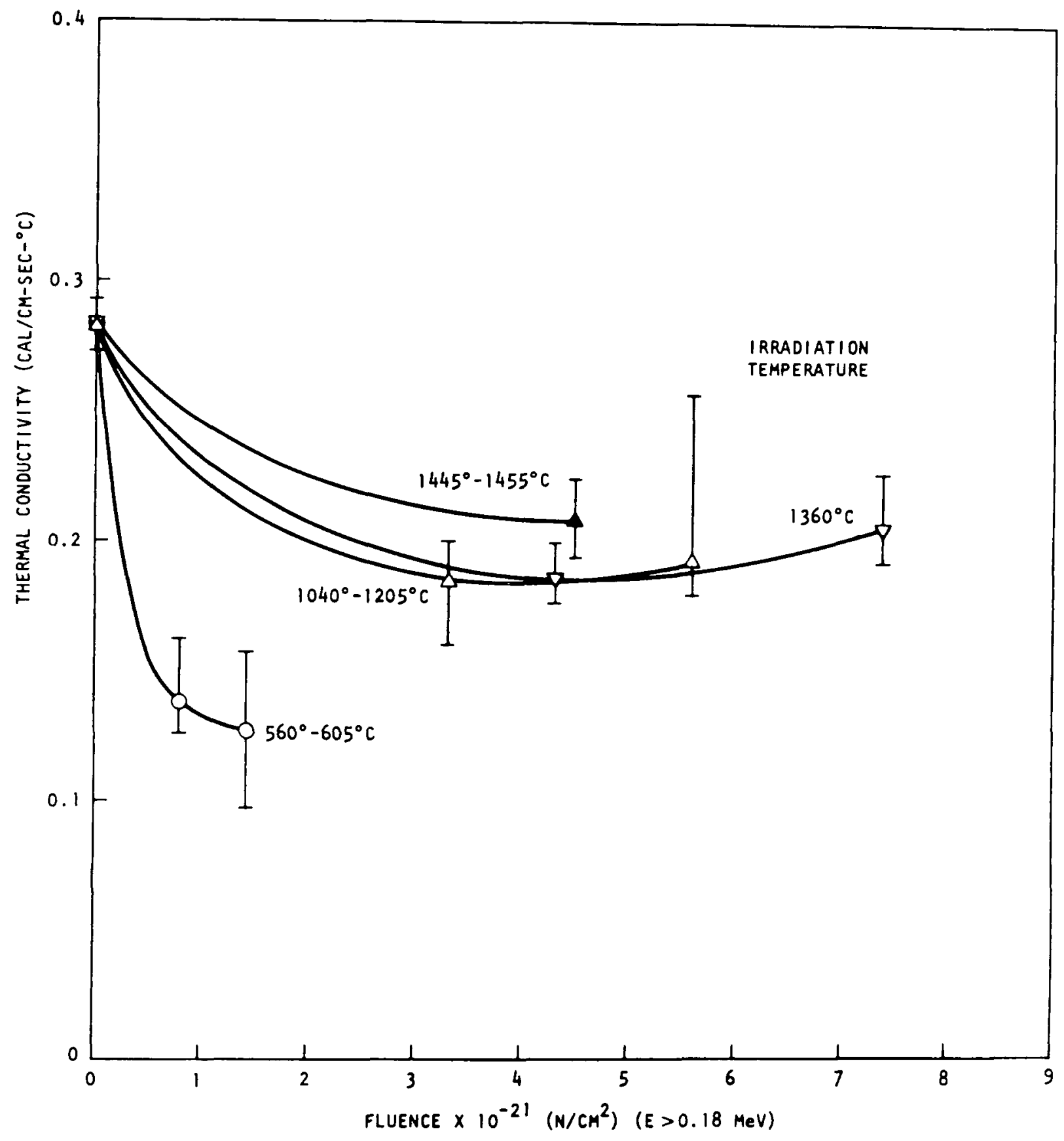

Fig. 3-10. Thermal conductivity versus fluence at $560^{\circ}$ to $1455^{\circ} \mathrm{C}$ for $\mathrm{H}-328$ graphite (perpendicular) 


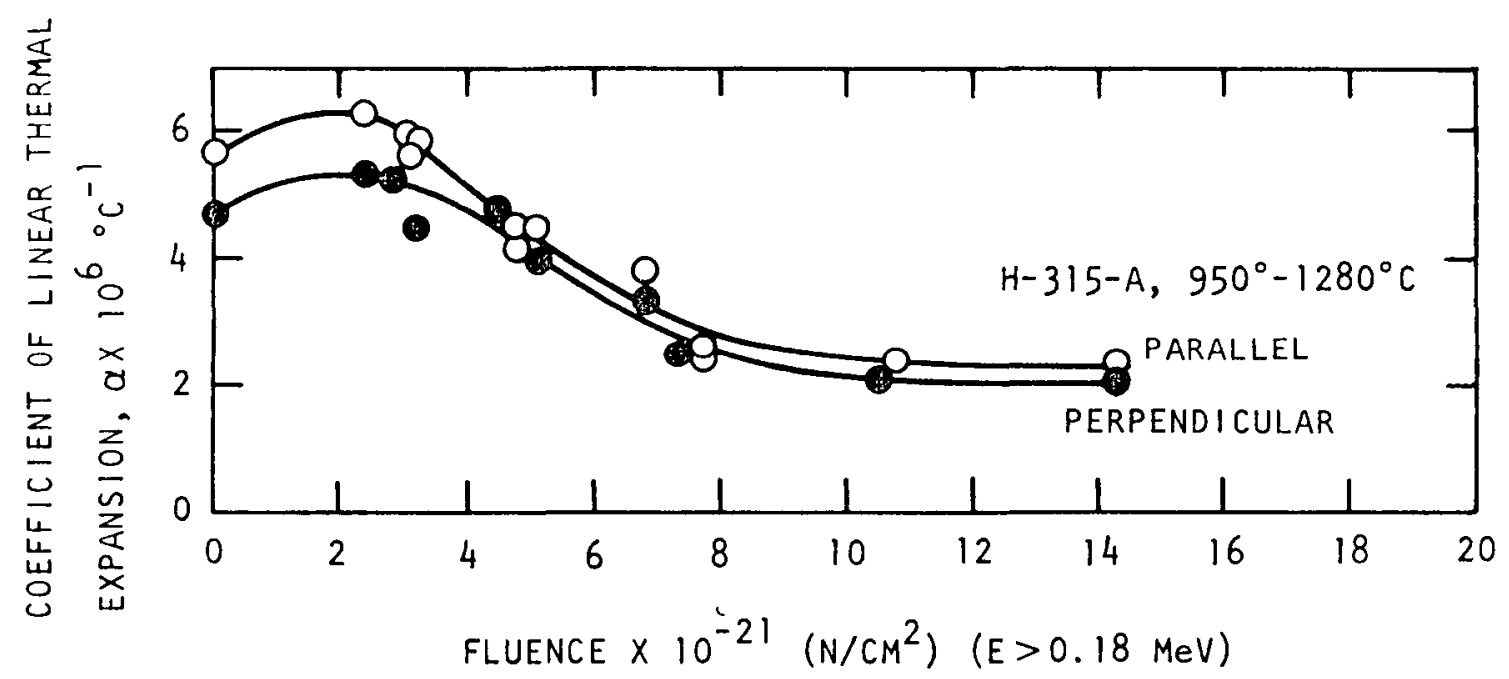

Fig. 3-11. Thermal expansivity changes of Gilsocoke graphite measured at $400^{\circ} \mathrm{C}$ as a function of neutron fluence 
designs in the U.S. HTGR designs in Europe are also being directed away from Gilsocoke graphites as described in the next section.

\subsection{NON-GILSOCOKE GRAPHITES FOR HTGRS IN EUROPE}

In 1969, technical personnel of the Dragon Project, KFA (Jülich), Euratom, and CEA (Saclay) initiated programs to develop European nearisotropic graphites based on petroleum coke or coal-tar pitch coke. Irradiation testing of several such graphites is under way. Some preliminary data from an extruded pitch-coke graphite are given in Refs. 7 and 15. The dimensional change behavior at low fluences is similar to that of Gilsocoke-based graphite (e.g., Figs. 3-4 and 3-9) except that contraction at $1400^{\circ} \mathrm{C}$ is more rapid than at $1200^{\circ} \mathrm{C}$. Curves showing fractional change in Young's modulus versus neutron fluence closely resemble those of Gilsocoke graphite (e.g., F1g. 3-6), while preliminary thermal expansivity data suggest that changes will be less marked than those of Gilsocoke graphite.

Other physical properties of the European near-isotropic petroleumand pitch-coke based graphites resemble those of Gilsocoke graphites fabricated similarly, except the initial thermal expansivities are lower. Typical values (measured between $20^{\circ}$ and $400^{\circ} \mathrm{C}$ ) are 5 to $6 \times 10^{-6}{ }^{\circ} \mathrm{C}^{-1}$ for Gilsocoke graphites, 4 to $5 \times 10^{-6}{ }^{\circ} \mathrm{C}^{-1}$ for pitch-coke graphites, and 2 to $4 \times 10^{-6}{ }^{\circ} \mathrm{C}^{-1}$ for petroleum-coke graphites. The lower thermal expansivity offers considerable reduction in component shutdown stresses.

Taking into account the lower costs and better raw material supply prospects, the new petroleum-coke-based or pitch-coke-based near-isotropic nuclear graphites appear likely to replace Gilsocoke-based graphites as reference materials for the design of European HTGRs. 


\section{MATERIALS}

Near-isotropic graphites and needle-coke graphites are described in this report. However, of the needle-coke graphites, data are presented for only $\mathrm{H}-327$, which is the fuel and reflector element graphite at Fort St. Vrain. A description of the graphites, along with their mean bulk densities and anisotropy factors, is given in Table 4-1.

\subsection{NEAR-ISOTROPIC GRAPHITES}

Beginning in 1969, cooperation between GAC and the major U.S. carbon companies under a USAEC research program resulted in the development of near-isotropic graphites made from petroleum-based near-isotropic cokes. The Great Lakes Carbon Company (GLCC) responded in early 1971 with a prototype grade $\mathrm{H}-429$ and late in 1972 with a production-size grade $\mathrm{H}-451$. The Union Carbide Corporation (UCC) responded in 1973 with production-size grade TS-1240. AirCo Speer expects to deliver their version of productionsize material in 1974 .

The near-isotropic graphites are manufactured with petroleum nearisotropic cokes, which are not currently used extensively for other products. The near-isotropic cokes are characterized by large volume fractions of fine isotropic microstructural constituents (Ref. 16) and the particles are near-isotropic. The manufacturing processes of the nearisotropic graphites are similar to those for the needle-coke graphites.

The grades of near-isotropic graphites described in this section are under study and data for these materials are included later in this report. 
TABLE 4-1

DESCRIPTION OF NEAR-ISOTROPIC AND H-327 GRAPHITES

\begin{tabular}{|c|c|c|c|c|c|c|c|c|c|}
\hline \multirow{2}{*}{$\begin{array}{c}\text { Graphite } \\
\text { Grade }\end{array}$} & \multirow[b]{2}{*}{ Manufacturer } & \multicolumn{2}{|c|}{ Log Size (in.) } & \multirow[b]{2}{*}{ Type } & \multirow[b]{2}{*}{ Filler Coke } & \multirow[b]{2}{*}{ Binder } & \multirow[b]{2}{*}{ Impregnant } & \multirow{2}{*}{$\begin{array}{l}\text { Mean } \\
\text { Bulk } \\
\text { Density } \\
\left(\mathrm{g} / \mathrm{cm}^{3}\right) \\
\end{array}$} & \multirow{2}{*}{$\begin{array}{c}\text { Anisotropy } \\
\text { Factor } \\
\alpha_{\perp} / \alpha_{1}\end{array}$} \\
\hline & & Diameter & Length & & & & & & \\
\hline$H-429$ & GLCC & 6.0 & - & $\begin{array}{l}\text { Near- } \\
\text { Isotropic }\end{array}$ & $\begin{array}{l}\text { Petroleum } \\
\text { (near- } \\
\text { isotropic) }\end{array}$ & $\begin{array}{l}\text { Coal-tar } \\
\text { pitch }\end{array}$ & $\begin{array}{l}\text { Coal-tar } \\
\text { pitch }\end{array}$ & 1.73 & 1.20 \\
\hline $\mathrm{H}-451$ & GLCC & 18.0 & 34.0 & $\begin{array}{l}\text { Near- } \\
\text { isotropic }\end{array}$ & $\begin{array}{l}\text { Petroleum } \\
\text { (near- } \\
\text { isotropic) }\end{array}$ & $\begin{array}{l}\text { Coal-tar } \\
\text { pitch }\end{array}$ & $\begin{array}{l}\text { Petroleum } \\
\text { pitch }\end{array}$ & 1.76 & 1.30 \\
\hline IS -1240 & UCC & 18.0 & 34.0 & $\begin{array}{l}\text { Near- } \\
\text { isotropic }\end{array}$ & $\begin{array}{l}\text { Petroleum } \\
\text { (near- } \\
\text { isotropic) }\end{array}$ & $\begin{array}{l}\text { Coal-tar } \\
\text { pitch }\end{array}$ & $\begin{array}{l}\text { Coal-tar } \\
\text { pitch }\end{array}$ & 1.77 & $1.20^{(a)}$ \\
\hline $\mathrm{P}_{3} \mathrm{JHAN}$ & Pechiney & 17.0 & 34.0 & $\begin{array}{l}\text { Near- } \\
\text { isotropic }\end{array}$ & $\begin{array}{l}\text { Coal-tar } \\
\text { pitch } \\
\text { (near- } \\
\text { isotropic) }\end{array}$ & $\begin{array}{l}\text { Coa1-tar } \\
\text { pitch }\end{array}$ & $\begin{array}{l}\text { Coal-tar } \\
\text { pitch }\end{array}$ & 1.72 & 1.40 \\
\hline $\mathrm{H}-327$ & GLCC & 18.0 & - & Anisotropic & $\begin{array}{l}\text { Petroleum } \\
\text { (needle) }\end{array}$ & $\begin{array}{l}\text { Coal-tar } \\
\text { pitch }\end{array}$ & $\begin{array}{l}\text { Coal-tar } \\
\text { pitch }\end{array}$ & 1.77 & 2.10 \\
\hline
\end{tabular}

(a) Data supplied by UCC. 
4.1.1. Great Lakes Carbon Company - Grades H-429 and H-451

\subsubsection{Grade $\mathrm{H}-429$}

Grade H-429 was manufactured by extrusion as a 6-in.-diameter experimental prototype near-isotropic graphite. Grade H-429 was manufactured with a near-isotropic coke and the supplier indicated it was similar in structure to the base graphite used to manufacture the sleeves for Peach Bottom Core 2. Grade H-429 was delivered on January 6, 1971.

\subsubsection{Grade $\mathrm{H}-451$}

Grade H-451 was manufactured by extrusion as an 18-in.-diameter by 34-in.-long experimental preproduction full-production-size near-isotropic graphite. Grade H-451 was first produced as a portion of an experimental furnace that contained other near-isotropic materials. It was manufactured with a proprietary coke and a coal-tar pitch binder and impregnated with petroleum pitch. The first logs of H-451 were delivered August 17, 1972 .

A second partial furnace lot of $\mathrm{H}-451$ was manufactured in an effort to improve its properties. These logs were delivered February 7, 1974.

A third partial furance lot of $\mathrm{H}-451$ is in process and will be delivered about May 1974 .

\subsubsection{Union Carbide Corporation, Carbon Products Division - Grade TS-1240}

Grade TS-1240 was manufactured by extrusion as 17-in.-diameter by 34-in.-long logs with a proprietary coke. Grade TS-1240 was produced as a full furnace production lot. The material was received on August 27, 1973. 
4.1.3. Pechiney Ugine Kuhlman Group - Grade $\mathrm{P}_{3}$ JHAN

Grade $\mathrm{P}_{3}$ JHAN is an extruded graphite manufactured with coal-tar pitch coke. It is currently being evaluated as an HTGR candidate core graphite by CEA, Saclay, France, for French HTGR designs. A small number of specimens were included in capsule $O G-1$ for comparative purposes.

\subsection{NEEDLE-COKE GRAPHITES}

The needle-coke graphites are manufactured with petroleum needle coke of the same type used to manufacture steel furnace electrodes. The needle coke is characterized by a large volume fraction of fine fibrous microstructural constituents (Ref. 16) and the particles are highly anisotropic. The coke is sized, mixed with coal-tar pitch binder, formed into green logs by extrusion, baked slowly to about $800^{\circ}$ to $900^{\circ} \mathrm{C}$ to carbonize the binder, and finally heated to about $2800^{\circ} \mathrm{C}$ to transform the structure to graphite. Purification of the graphite can be accomplished during the graphitizing process. The resulting material is highly anisotropic in properties and irradiation behavior. Three companies, GLCC, UCC, and AirCo Speer, have supplied needle-coke graphites.

\subsubsection{Great Lakes Carbon Company - Grade H-327}

An extruded needle-coke graphite (grade $\mathrm{H}-327$ ) is the current reference material for large HTGRs. Great Lakes Carbon Company grade H-327 was manufactured for replaceable fuel and reflector blocks for the Fort St. Vrain reactor. Great Lakes Carbon Company manufactured three preproduction lots for experimental and qualification purposes prior to the production lots for Fort St. Vrain. The production material exceeded GAC's material specification for density, strength, and purity and was superior to the preproduction material. A large amount of test data obtained during the production and qualification of H-327 for Fort St. Vrain is available on this material. 
4.2.2. Union Carbide Corporation, Carbon Products Division - Grade TS-1111

Grade TS-1111 is similar to grade H-327. It is UCC's candidate needlecoke material. No data are presented for this graphite.

4.2.3. AirCo Speer Carbon Company - Grade 9567

Grade 9567 is similar to grade $\mathrm{H}-327$. Based on a low level of preliminary testing, grade 9567 appears to meet GAC's material specification. No data are presented for this graphite. 


\section{EXPERIMENTAL METHODS}

5.1. CAPSULE OG-1

Capsule OG-1 was a fully instrumented graphite irradiation capsule irradiated for 3200 full power hours in the C-3 position of the Oak Ridge Reactor. It contained two cells, each with its own sweep-gas system to facilitate independent temperature control in the upper and lower parts of the capsule. The two cells contained a total of ten graphite crucibles approximately $2.25 \mathrm{in.}$ in diameter by $2 \mathrm{in.} \mathrm{high} \mathrm{(one} \mathrm{crucible} \mathrm{was} 3 \mathrm{in}$. high), which were drilled with holes to act as sample holders. The centerline temperature of one crucible in the upper cell and one crucible in the lower cell was maintained at $1000^{\circ} \mathrm{C}$ during reactor operation by adjustment of the gas mixtures. Centerline temperatures of all crucibles, and peripheral temperatures of eight out of ten crucibles, were monitored with chromel-alumel or tungsten-rhenium thermocouples. The output of the tungsten-rhenium thermocouples was corrected for neutron-induced decalibration using the output from three pairs of adjacent chromel-alumel and tungsten-rhenium thermocouples. Fast neutron fluences ( $\mathrm{E}>0.18 \mathrm{MeV}$ ) were derived from the activation of iron and titanium dosimeter wires, using cross sections of $46.5 \mathrm{mb}$ for the ${ }^{54} \mathrm{Fe}(\mathrm{n}, \mathrm{p}){ }^{54} \mathrm{Mn}$ reaction and $6.85 \mathrm{mb}$ for the ${ }^{46} \mathrm{Ti}(\mathrm{n}, \mathrm{p}){ }^{46} \mathrm{Sc}$ reactions. Thermal fluences were measured from cobalt dosimeters assuming a value of $36.8 \mathrm{~b}$ for the cross section for the ${ }^{59} \mathrm{Co}(\mathrm{n}, \alpha){ }^{60} \mathrm{Co}$ reaction. The mean temperatures and fluences in each cructible are listed in Table 5-1.

The sample holes contalned three types of graphite samples: 0.2-in.diameter by 0.45-in.-long cylinders for dimensional and thermal expansivity measurements, 0.25-in.-diameter by 0.9-in.-long cylinders for dimensional and tensile property measurements, and 0.40-in.-diameter by 0.05-in.-thick discs for thermal diffusivity measurements. Some of the small cylinders 
TABLE 5-1

MEAN TEMPERATURES AND FLUENCES IN CAPSULE OG-1

\begin{tabular}{c|c|c|c|c}
\hline \multirow{2}{*}{$\begin{array}{c}\text { Crucible } \\
\text { Number }\end{array}$} & $\begin{array}{c}\text { Fast Fluence } \\
\text { x } 10^{-21}\left(\mathrm{n} / \mathrm{cm}^{2}\right) \\
(\mathrm{E}>0.18 \mathrm{MeV})\end{array}$ & $\begin{array}{c}\text { Thermal Fluence } \\
\mathrm{x} 10^{-21}\left(\mathrm{n} / \mathrm{cm}^{2}\right)\end{array}$ & \multicolumn{2}{|c}{ Mean Temperature $\left({ }^{\circ} \mathrm{C}\right)$} \\
\cline { 3 - 5 } 1 & 2.2 & 1.4 & 657 & 558 \\
2 & 2.9 & 1.7 & 754 & 610 \\
3 & 3.4 & 1.9 & 993 & 887 \\
4 & 3.7 & 2.0 & 1172 & 1024 \\
5 & 3.6 & 2.0 & 1395 & 1327 \\
6 & 3.4 & 1.8 & 1078 & 938 \\
7 & 3.1 & 1.6 & 992 & 884 \\
8 & 2.6 & 1.4 & 928 & 836 \\
9 & 2.1 & 1.1 & 860 & 753 \\
10 & 1.6 & 0.8 & 650 & 597 \\
\hline
\end{tabular}


and discs had been previously irradiated in earlier capsules and were included in order to obtain higher fluence data.

\subsection{DIMENSIONAL MEASUREMENTS}

Dimensions (length) of both unirradiated and irradiated specimens were obtained using a Bausch and Lomb DR-25B optical gage. Measurements were made to the nearest 0.00002 in. according to manufacturer's recommended practices.

\subsection{DENSITY}

The bulk density was measured according to ASTM Standard Test Method C-559.

\subsection{TENSILE PROPERTIES}

\subsubsection{Stress-Strain Curves}

Tensile stress-strain curves were obtained in air at room temperature on unirradiated and irradiated samples using an Instron tensile machine. Tensile tests were conducted on standard (0.505-in.-diameter by 3-in.-long, unirradiated only) and subsize (0.25-in.-diameter by 0.9-in.-1ong, unirradiated and irradiated) samples using a crosshead speed of $0.005 \mathrm{in.} / \mathrm{min}$. Strains were measured for subsize samples using a 0.5-in. gage length nonaveraging clip-on extensometer. A 2.0-in. gage length averaging extensometer was used on standard samples. The samples were fixed to metal end pieces with high-strength epoxy cement, and the load was applied through roller-link chains to maintain uniaxial alignment during testing.

Irradiated samples were tested using a cyclic loading method. Each sample was loaded to 1000 psi (600 psi for H-327 graphite samples of perpendicular orientation) and the crosshead motion reversed. After unloading to $\sim 100$ psi the crosshead was again reversed, and the sample was extended 
until it fractured. Some unirradiated subsize samples (controls) were tested in this manner.

Unirradiated standard and subsize specimens (except as noted above) were tested to fracture without crosshead reversal.

Typical stress-strain curves for both methods are shown in Fig. 5-1.

\subsubsection{Tensile Strength}

The tensile strength of all samples was calculated by dividing the load at fracture (stress corresponding to point q, Fig. 5-1) by the original cross-sectional area of the specimen.

\subsubsection{Modulus of Elasticity}

\subsubsection{Young's Modulus}

Young's modulus for samples tested by the cyclic loading method (irradiated and subsize control samples) was calculated from the slope of the linear stress-strain curve after load reversal (1ine o'p, Fig. 5-1a).

Young's modulus for samples tested by the standard method (unirradiated only) was calculated from the stress-strain curve as the initial tangent modulus, the slope of the curve at the origin (tangent line op, Fig. $5-1 b)$.

\subsubsection{Chord Modulus}

The chord modulus for samples tested by the standard method (unirradiated only) was calculated from the stress-strain curve as the slope of the chord drawn between points on the curve for stresses of 250 and 500 psi (chord rs, Fig. 5-1b). 


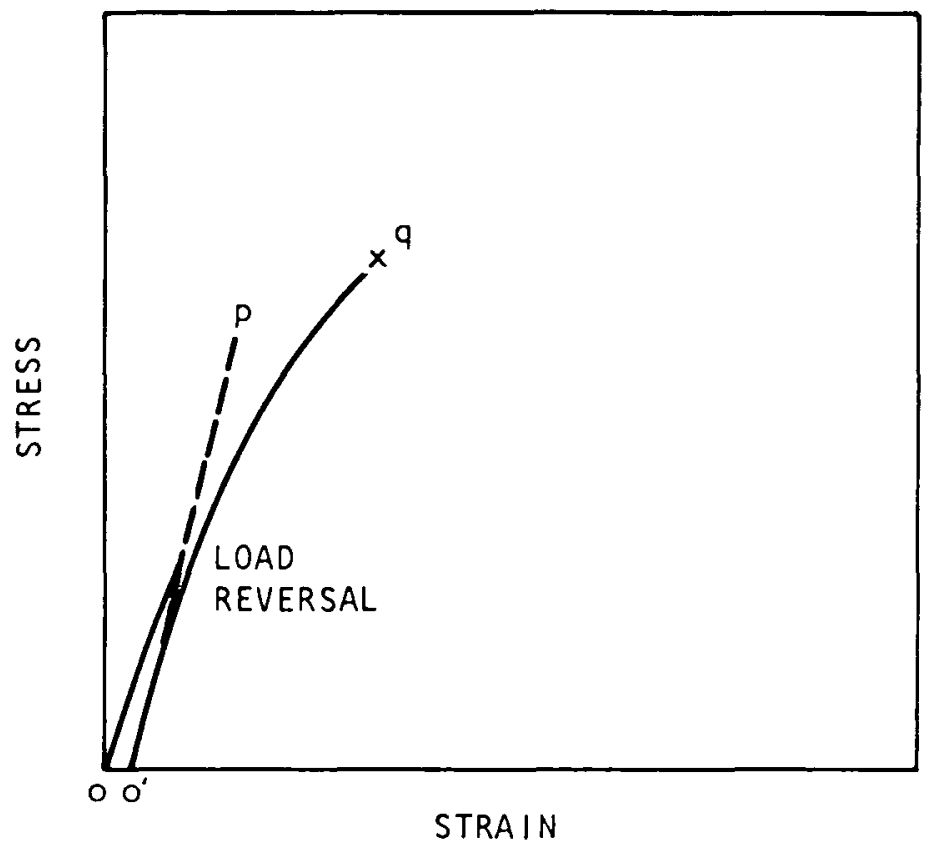

(a)

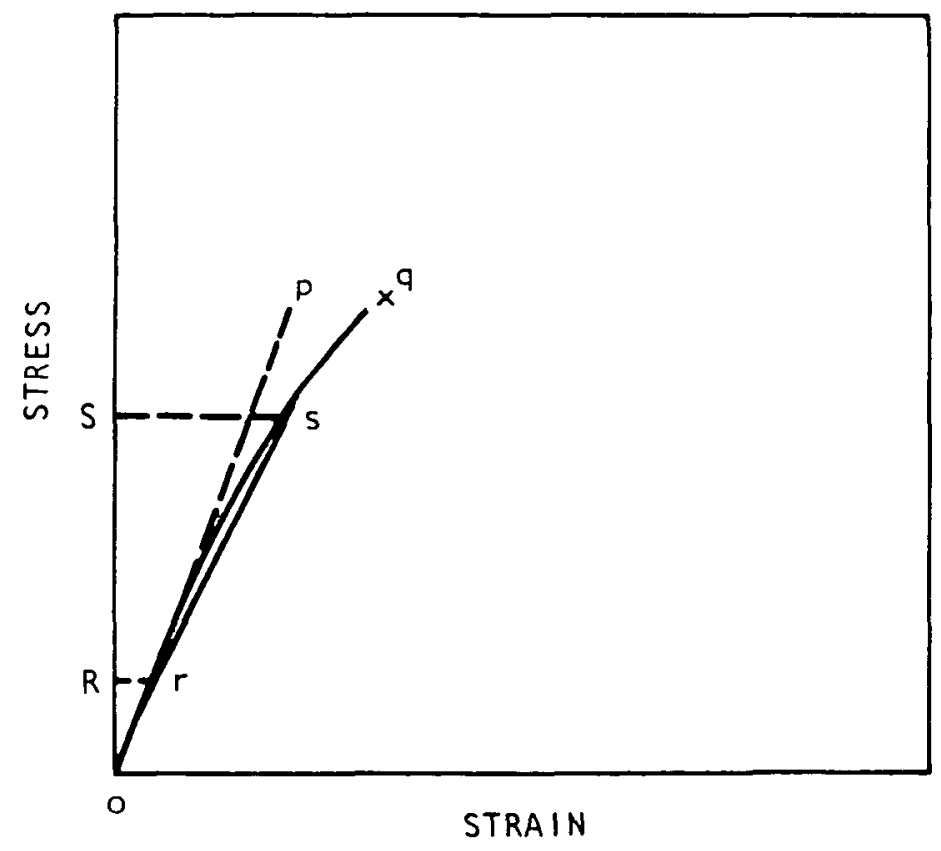

(b)

Fig. 5-1. Stress-strain curves for graphite 


\subsubsection{Strain at Fracture}

The strain at fracture for all samples was taken as the maximum strain as indicated on the stress-strain curve (strain corresponding to point $q$, Fig. 5-1).

\subsubsection{Poisson's Ratio}

Poisson's ratio was obtained on unirradiated samples, 0.505 in. in diameter by $5 \mathrm{in.}$ long and $0.5 \mathrm{in}$. by $0.5 \mathrm{in}$. by $5 \mathrm{in.}$ long, using a strain gage method. Multiple (two to four) biaxial strain gages, equidistant around the cross section, were aligned with the longitudinal and transverse directions of each specimen and attached in position with an epoxy cement. The samples were fixed to end pieces with a high-strength epoxy cement and were loaded in tension in steps to 1500 psi while recording the strains from each gage. The load was applied through roller-link chains to maintain uniaxial alignment during testing. The transverse and longitudinal strains for each gage were measured at each load using a Vishay, Inc., digital strain indicator. Poisson's ratio was calculated from the ratio of transverse and longitudinal strains for each biaxial gage after first correcting each strain for transverse sensitivity.

\subsection{THERMAL CONDUCTIVITY}

Thermal diffusivity measurements were made on disc samples, $0.45 \mathrm{in}$. in diameter by $0.050 \mathrm{in.} \mathrm{thick,} \mathrm{by} \mathrm{the} \mathrm{heat} \mathrm{pulse} \mathrm{method} \mathrm{(ASTM} \mathrm{Method} \mathrm{of}$ Test $\mathrm{C}-741)$. The thermal conductivity was calculated from the following equation:

$$
k=\alpha C_{p} \rho,
$$

where $\alpha=$ thermal diffusivity

$$
\begin{aligned}
& C_{p}=\text { heat capacity } \\
& \rho=\text { density }
\end{aligned}
$$


Unirradiated specimens were measured at $100^{\circ} \mathrm{C}$ intervals from room temperature to $800^{\circ} \mathrm{C}$. Irradiated specimens were measured at room temperature only or at $100^{\circ} \mathrm{C}$ intervals from room temperature to $100^{\circ} \mathrm{C}$ less than the irradiation temperature (up to a maximum of $800^{\circ} \mathrm{C}$ ).

\subsection{THERMAL EXPANSIVITY}

Thermal expansivity measurements were made on cylindrical samples, $0.20 \mathrm{in.}$ in diameter by $0.45 \mathrm{in.}$ long, using a silica dilatometer. Unirradiated specimens were measured between room temperature and $1000^{\circ} \mathrm{C}$. Irradiated specimens were measured between room temperature and $100^{\circ} \mathrm{C}$ less than the irradiation temperature. ASTM Method of Test E-228 was followed.

\subsection{CHEMICAL IMPURITIES}

Unirradiated samples were analyzed for $B, F e, V$, and $T i$ by a standard spectrographic method and for ash by burning in a covered crucible in air.

\subsection{OXIDATION RATE}

Oxidation rates were obtained by measuring the weight loss of samples heated in the quartz envelope of a recording microbalance. Thin slabs, $1 / 8 \mathrm{in.} \mathrm{thick} \mathrm{by} 1 / 2 \mathrm{in.}$ by $1 \mathrm{in.}$, were subjected to a flowing $3 \%$ steamhelium mixture at temperatures of $700^{\circ}$ to $1050^{\circ} \mathrm{C}$ for several hundred hours. During each test weight losses were continuously recorded on the microbalance. The oxidation rate was calculated as the percent sample weight change per hour.

\subsection{CESIUM SORPTION}

Cesium sorption measurements were made by annealing the samples with a cesium source for two 8 -hr periods in a sealed tantalum container. The source was prepared by loading H-327 graphite of 44 to $74 \mathrm{Hm}$ size with cesium nitrate containing a small amount of Cs-137 tracer. The relative 
sorptivity of each sample with respect to $\mathrm{H}-327$ graphite was deduced from the weights of the sample and the $\mathrm{H}-327$ graphite source and their cesium concentrations. Appropriate factors were introduced to correct for differences in sample and source forms. 


\section{EXPERINENTAL DATA}

\subsection{PROPERTIES OF UNIRRADIATED GRAPHITES}

The candidate near-isotropic graphites are received as logs approximately $18 \mathrm{in.}$ in diameter by $34 \mathrm{in.} \mathrm{long.} \mathrm{Past} \mathrm{experience} \mathrm{(Refs.} \mathrm{16,} \mathrm{17)}$ has shown commercial graphites of this size to have variations of microstructure and properties within a single log. Therefore, it is necessary to characterize a $\log$ by measuring the properties at the center of the $\log$ [midlength center (MLC) and end center (EC)] and at the surface or edge [midlength edge (MLE)].

The following properties were measured on a number of near-isotropic logs: (1) bulk density, (2) thermal expansivity, (3) thermal conductivity, (4) tensile properties including ultimate strength, strain at fracture, modulus of elasticity, and Poisson's ratio, (5) impurity concentrations, and (6) oxidation rates in a mixture of helium and steam.

\subsubsection{Bulk Density}

The bulk densities of graphites $H-451$ and TS-1240 are given in the Appendix, Tables $\mathrm{A}-1$ and $\mathrm{A}-2$, respectively. The near-isotropic graphites show low variation in bulk density from the center to the edge of the $10 \mathrm{~g}$. However, variation from $\log$ to $\log$ was observed.

\subsubsection{Thermal Expansivity}

Thermal expansivity mean values for near-isotropic graphites $\mathrm{H}-451$, 1l-429, and $\mathrm{P}_{3}$ JHAN are given in the Appendix, Tables $A-3$ through $A-5$, and mean values for $11-327$ are given in Table $A-6$. The near-isotropic graphites exhibit higher thermal expansivities in both directions than the needle- 
coke 1l-327 graphite. The small variation in thermal expansivitity values throughout the $11-451 \mathrm{log}$ is an indication that the material has a uniform distribution of properties throughout the $10 \mathrm{~g}$. These data illustrate the uniform microstructure and properties of near-isotropic graphites compared with the anisotropic graphites.

\subsubsection{Therma1 Conductivity}

The thermal. conductivity values for the near-isotropic graphites are given in the Appendix, Tables $\mathrm{A}-7$ and $\mathrm{A}-8$, and those for $\mathrm{H}-327$ in Table A-9. H-451 and H-327 have comparable thermal conductivity values in the radial direction, while those of TS -1240 were slightly lower.

\subsubsection{Mean Values of Thermal Expansivity and Thermal Conductivity of Graphites}

The mean values for thermal expansivity and thermal conductivity of the candidate graphites can be compared in Table 6-1.

\subsubsection{Tensile Properties}

\subsubsection{Ultimate Tensile Strength, Modulus of Elasticity, and Strain at Fracture}

The tensile property data are given in the Appendix, Tables A-10 through A-12. These data were measured on 0.505-in.-diameter by 3.0- or 4.0-in.-long and 0.250-in.-diameter by 0.90-in.-1ong specimens. The mean tensile properties of $\mathrm{H}-451$ and $\mathrm{H}-327$ graphite are compared in Table $6-2$. In the axial direction, the ultimate tensile strength (UTS) of the two graphites is about the same, but $\mathrm{H}-327$ is noticeably stiffer as evidenced by higher chord modulus values between 250 and 500 psi [ $E_{\text {chord }}(250-500)$ ] and the lower values of strain to failure $\left(\varepsilon_{f}\right)$. Graphite $H-451$ is noticeably stronger in the radial direction. The near-isotropic graphite is also stiffer than $H-327$ in the radial direction. 
TABLE 6-1

MEAN VALUES OF THERMAL PROPERTIES OF CANDIDATE GRAPHITES

\begin{tabular}{|c|c|c|c|c|c|c|c|c|}
\hline \multirow[b]{2}{*}{ Type } & \multirow[b]{2}{*}{ Grade } & \multirow[b]{2}{*}{ Orientation } & \multirow{2}{*}{$\begin{array}{l}\text { Location } \\
\text { in Log }\end{array}$} & \multirow{2}{*}{$\begin{array}{c}\text { Mean } \\
\text { Thermal } \\
\text { Expansivity, } \\
\alpha \times 10^{\circ} \mathrm{C}-1 \\
\left(22^{\circ}-500^{\circ} \mathrm{C}\right) \\
\end{array}$} & \multicolumn{4}{|c|}{$\begin{array}{l}\text { Thermal Conductivity } \\
\left(\mathrm{cal} / \mathrm{cm}-\mathrm{sec}-{ }^{\circ} \mathrm{C}\right)\end{array}$} \\
\hline & & & & & $22^{\circ} \mathrm{C}$ & $200^{\circ} \mathrm{C}$ & $500^{\circ} \mathrm{C}$ & $800^{\circ} \mathrm{C}$ \\
\hline \multirow[t]{8}{*}{ Near-isotropic } & \multirow[t]{2}{*}{$H-451$} & Perpendicular & $\begin{array}{l}\text { MLC } \\
\text { MLE }\end{array}$ & $\begin{array}{l}4.41 \\
4.49\end{array}$ & 0.294 & 0.262 & 0.204 & 0.158 \\
\hline & & Parallel & $\begin{array}{l}\text { MLC } \\
\text { MLE }\end{array}$ & $\begin{array}{l}3.45 \\
3.45\end{array}$ & 0.347 & 0.302 & 0.226 & 0.174 \\
\hline & \multirow[t]{2}{*}{ TS -1240} & Perpendicular & $\mathrm{MLC}$ & $3.82^{(a)}$ & 0.235 & 0.213 & 0.171 & 0.134 \\
\hline & & Parallel & MLC & $3.30^{(a)}$ & 0.245 & 0.222 & 0.173 & 0.136 \\
\hline & \multirow{2}{*}{$P_{3}$ JHAN } & Perpendicular & -- & 4.33 & -- & -- & -- & -- \\
\hline & & Parallel & -- & 3.16 & -- & -- & - & -- \\
\hline & \multirow[t]{2}{*}{$\mathrm{H}-429$} & Perpendicular & --- & 5.0 & -- & -- & -- & - \\
\hline & & Parallel & --- & 4.25 & -- & -- & -- & -- \\
\hline \multirow[t]{2}{*}{ Anisotropic } & \multirow[t]{2}{*}{$\mathrm{H}-327$} & Perpendicular & --- & 3.35 & 0.331 & 0.262 & 0.183 & 0.140 \\
\hline & & Parallel & --- & 1.60 & 0.450 & 0.332 & 0.267 & 0.194 \\
\hline
\end{tabular}

(a) Data supplied by manufacturer. 
TABLE 6-2

AVERAGE TENSILE PROPERTIES OF H-451 AND H-327 GRAPHITE SAMPLES

(SAMPLES 0.505 IN. IN DIANETER AND 4 IN. LONG)

\begin{tabular}{|c|c|c|c|c|c|c|c|c|c|c|}
\hline \multirow[b]{3}{*}{ Grade } & \multirow[b]{3}{*}{ Orientation } & \multicolumn{9}{|c|}{ Location in Log } \\
\hline & & \multicolumn{3}{|c|}{ End Center } & \multicolumn{3}{|c|}{ Midlength Center } & \multicolumn{3}{|c|}{ Midlength Edge } \\
\hline & & $\begin{array}{c}\text { UTS } \\
\text { (psi) }\end{array}$ & $\begin{array}{c}E_{\text {chord }} \times 10^{-6} \\
(250-500) \\
(p s i)\end{array}$ & $\begin{array}{c}\varepsilon_{f} \times 10^{2} \\
\text { (in./in.) }\end{array}$ & $\begin{array}{c}\text { UTS } \\
\text { (psi) }\end{array}$ & $\begin{array}{c}E_{\text {chord }} \times 10^{-6} \\
(250-500) \\
(p s i)\end{array}$ & $\begin{array}{c}\varepsilon_{f} \times 10^{2} \\
(\mathrm{in} . / \mathrm{in} .)\end{array}$ & $\begin{array}{c}\text { ITS } \\
\text { (pSI) } \\
\end{array}$ & $\begin{array}{c}E_{\text {chord }} \times 10^{-6} \\
(250-500) \\
(p s i)\end{array}$ & $\begin{array}{l}E_{f} \times 10^{2} \\
\text { (in./in.) }\end{array}$ \\
\hline $\mathrm{H}-451$ & Parallel & 1889 & 1.22 & 0.196 & 1776 & 1.23 & 0.188 & 2215 & 1.28 & 0.237 \\
\hline $\mathrm{H}-327$ & Parallel & 2180 & 1.51 & 0.193 & 1629 & 1.54 & 0.148 & 2394 & 1.75 & 0.211 \\
\hline $\mathrm{H}-451$ & Perpendicular & 1396 & 0.96 & 0.173 & 1262 & 0.93 & 0.158 & 1465 & 0.94 & 0.181 \\
\hline $\mathrm{H}-327$ & Perpendicular & 1349 & 0.69 & 0.287 & 924 & 0.58 & 0.208 & 1293 & 0.65 & 0.274 \\
\hline
\end{tabular}


Experience with GLCC indicates that production-scale nuclear graphites exhibit higher UTS values than preproduction samples, which implies that H-451 has a high probability of being stronger than $\mathrm{H}-327$ without the severe strength gradient evident in the needle-coke graphite.

\subsubsection{Poisson's Ratio}

Poisson's ratio for H-451 graphite has been measured as a function of orientation and location in a $\log$ at stresses up to $1500 \mathrm{psi}$. The longitudinal and transverse strains for the measurements were obtained with biaxial strain gages attached to one or more surfaces of each specimen.

Poisson's ratio was found to decrease slightly with increasing stress during initial loading and reached a constant value for all stresses after three or four loadings. The values obtained for each specimen after several loadings are shown in Table 6-3. The Poisson's ratios for each location and orientation differ by approximately $\pm 10 \%$ and their average is 0.123 .

\subsubsection{Impurity Concentrations}

The chemical impurities found in $\mathrm{H}-451$, TS-1240, and $\mathrm{P}_{3}$ JHAN graphite are given in the Appendix, Tables A-13 through A-15. With a few exceptions, the impurities are uniformly distributed throughout the graphite logs.

\subsubsection{Effects of Steam-Graphite Oxidation $-\mathrm{H}-451$ and $\mathrm{H}-327$}

Graphite will undergo measurable chemical oxidation by steam at temperatures in excess of $700^{\circ} \mathrm{C}$ according to the equation:

$$
\mathrm{H}_{2} \mathrm{O}+\mathrm{C} \rightarrow \mathrm{CO}+\mathrm{H}_{2}+\Delta \mathrm{H} \quad,
$$

where the endothermic heat of reaction, $\Delta \mathrm{H}$, is $+31.14 \mathrm{kcal} / \mathrm{mole}$. The steam-graphite reaction has been extensively investigated by numerous research groups in an effort to elucidate the kinetics of the reaction 
TABLE 6-3

POISSON'S RATIO FOR GRADE H-451 GRAPHITE

(Log Number 5651-28)

\begin{tabular}{|c|c|c|c|c|c|c|c|}
\hline \multirow[b]{2}{*}{$\begin{array}{c}\text { Specimen } \\
\text { No. }\end{array}$} & \multirow[b]{2}{*}{$\begin{array}{l}\text { Specimen } \\
\text { Size (in.) }\end{array}$} & \multirow[b]{2}{*}{$\begin{array}{l}\text { No. of Biaxial } \\
\text { Gages }\end{array}$} & \multirow{2}{*}{$\begin{array}{l}\text { Location and } \\
\text { Orientation } \\
\text { (Stress.Axis) }\end{array}$} & \multicolumn{4}{|c|}{ Poisson's Ratio } \\
\hline & & & & $\begin{array}{c}11 \text { to } \\
\text { Extrusion }\end{array}$ & $\begin{array}{c}1 \text { to } \\
\text { Extrusion }\end{array}$ & $\begin{array}{c}11 \text { to } \\
\text { Radius }\end{array}$ & $\begin{array}{c}1 \text { to } \\
\text { Radius }\end{array}$ \\
\hline $5947-102-1$ & $0.5 \times 0.5 \times 6$ long & $2\left(90^{\circ}\right.$ apart $)$ & $\operatorname{MLC}(1)$ & 0.120 & 0.136 & & \\
\hline $5947-102-2$ & $0.5 \times 0.5 \times 6$ long & $4\left(90^{\circ}\right.$ apart $)$ & MLC (1) & $0.116^{(a)}$ & $0.128^{(a)}$ & & \\
\hline $5947-102-4$ & $0.5 \times 0.5 \times 6$ long & $2\left(90^{\circ}\right.$ apart $)$ & $M L C \quad(\|)$ & & & 0.134 & 0.118 \\
\hline $5947-102-5$ & 0.505 diam. $x 6$ long & $3\left(120^{\circ}\right.$ apart $)$ & $\operatorname{MLC}(\|)$ & & & 0.13 & (b) \\
\hline $5651-28-133$ & $0.5 \times 0.5 \times 6$ long & $4\left(90^{\circ}\right.$ apart $)$ & $\operatorname{MLE}(\mathbb{H})$ & & & $0.123^{(a)}$ & $0.110^{(a)}$ \\
\hline Average & -- & -- & $\operatorname{MLC}(1)$ & 0.125 & \pm 0.010 & & \\
\hline Average & --- & --- & $\operatorname{MLC}(\|)$ & & & 0.127 & 0.008 \\
\hline Average & -- & -- & $\operatorname{MLE}(\|)$ & & & 0.117 & 0.007 \\
\hline
\end{tabular}

\footnotetext{
(a) Average of values obtained from two gages on opposite faces.

(b) Average of values obtained from all gages.
} 
(Refs. 18, 19). The expression most commonly formulated for the rate of reaction follows the generalized Langmuir-Hinshelwood form, in which the rate is dependent on steam and hydrogen partial pressures and temperaturedependent Arrhenius coeficients:

$$
R=\frac{K_{1} P_{H_{2} O} F_{b} F_{c}}{1+K_{2} P_{H_{2}}^{n}+K_{3} P_{H_{2} O}}
$$

In this expression, $R$ is the local graphite mass fraction or percent reacting per unit time, $\mathrm{P}_{\mathrm{H}_{2}} \mathrm{O}$ and $\mathrm{P}_{\mathrm{H}_{2}}$ are local partial pressures of steam and hydrogen, $F_{b}$ and $F_{c}$ are modifiers for the effects of prior reaction (burnoff) and catalysts, and the terms $k_{1}, k_{2}$, and $k_{3}$ are reaction rate and sorption constants.

Computer codes have been developed for analysis of the steam-graphite reaction in the HTGR core. These codes are OXIDE (Ref. 20), which was developed at GAC, and GOP (Ref. 21), which was developed at BNWL. Both codes utilize forms of the Langmulr-Hinshelwood equation but also include mass transport to and through the porous graphite substrate, core temperature profiles, and proper coolant flow geometry.

Much experimental work on the steam-graphite reaction has been documented. Results were reported for H-327 and AGOT graphites oxidized via high partial pressures of steam $(2.8 \%)$ in helium at temperatures ranging from $750^{\circ}$ to $1050^{\circ} \mathrm{C}$ (Ref. 22). An Arrhenius plot of the data in Fig. 6-1 verifies that $\mathrm{H}-327$ has an overall activation energy $(28.8 \mathrm{kcal} / \mathrm{mole})$ and reaction rate similar to other typical nuclear graphites (i.e., AGOT graphite).

Preliminary oxidation rate data on small samples of preproduction H-451 are shown in Fig. 6-2. These results show the oxidation rate behavior and activation energy $(25.2 \mathrm{kcal} / \mathrm{mole})$ of $\mathrm{H}-451$ are quite similar 


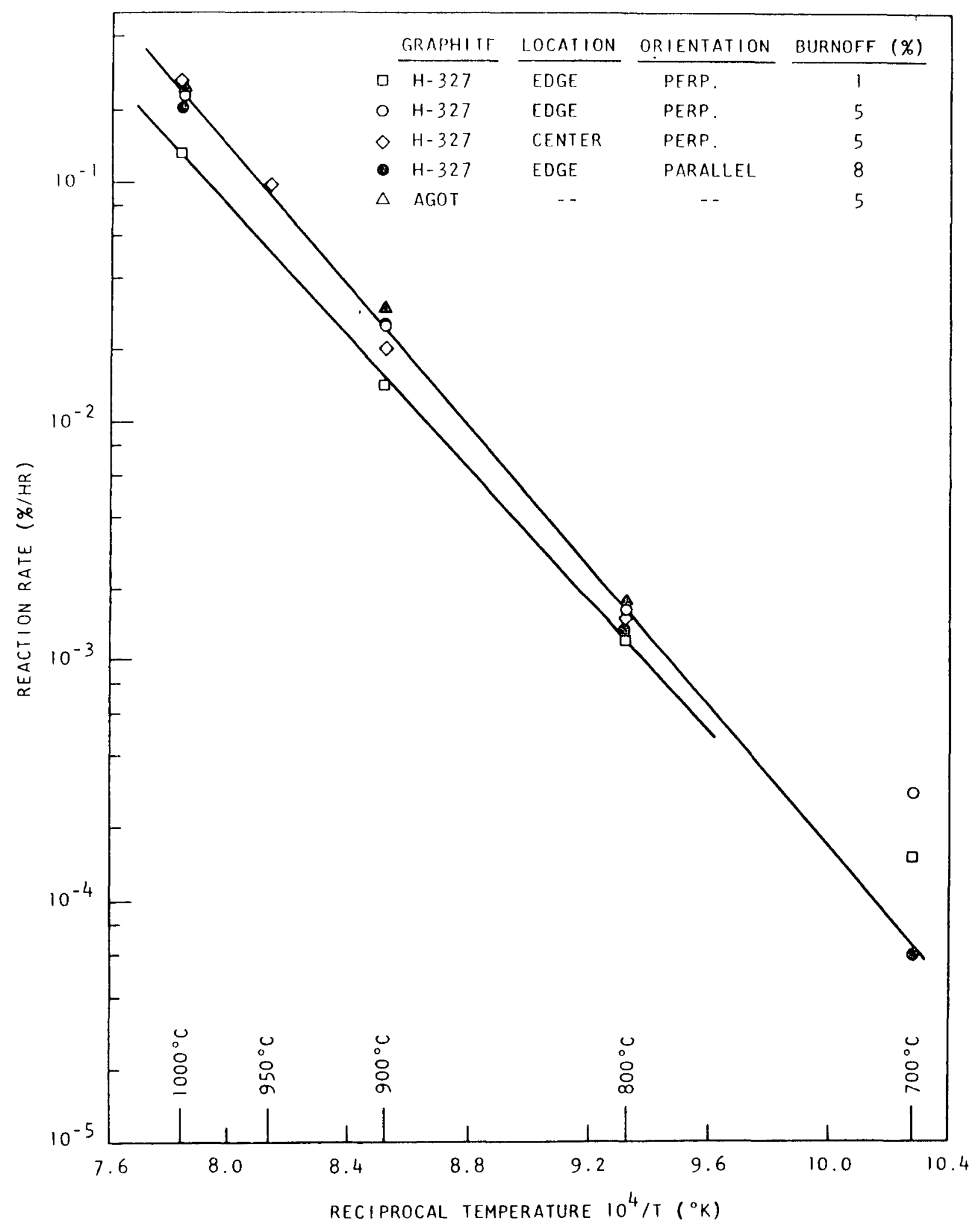

Fig. 6-1. Temperature dependence of steam-graphite reaction rate data measured at conditions of $2.8 \% \mathrm{H}_{2} \mathrm{O}$ in helium with a helium flow rate of about $150 \mathrm{~cm}^{3} / \mathrm{min}$ 


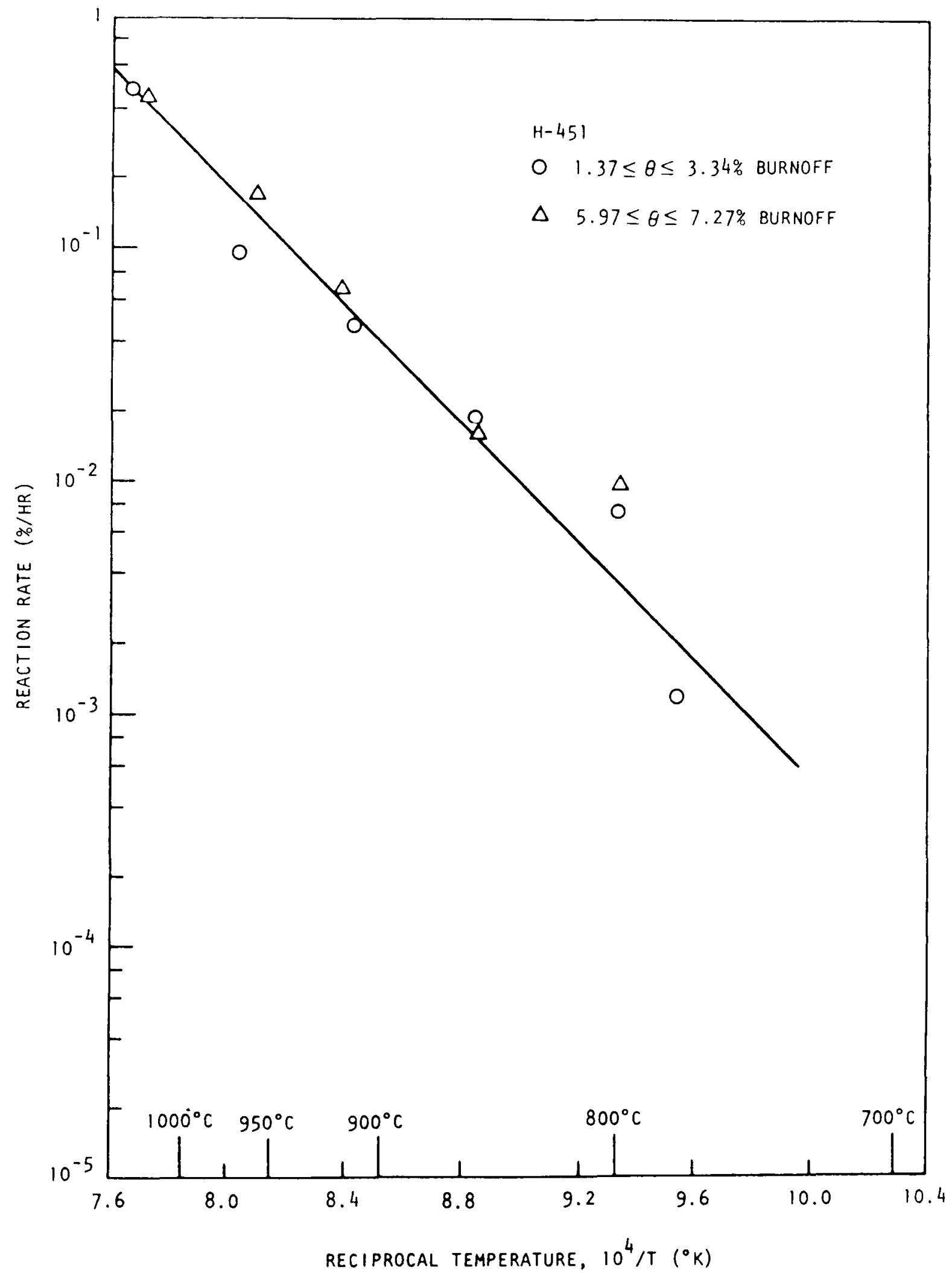

Fig. 6-2. Temperature dependence of steam-graphite reaction rate data measured at conditions of $2.8 \% \mathrm{H}_{2} \mathrm{O}$ in helium with a helium flow rate of about $100 \mathrm{~cm} 3 / \mathrm{min}$ 
to $\mathrm{H}-327$ and AGOT graphites. Thus, $\mathrm{H}-451$ is expected to behave very much like previously approved nuclear graphites.

\subsection{IRRADIATION BEHAVIOR}

The results of recent irradiation tests at GAC on near-isotropic graphites are presented in this section. The bulk of the data was obtained on grades $\mathrm{H}-451$ and $\mathrm{H}-429$. New data are also available on grade $\mathrm{H}-327$, along with a small amount of data on grade $\mathrm{P}_{3}$ JHAN which was irradiated for comparative purposes. The $\mathrm{H}-451 / \mathrm{H}-429$ data are compared to the $\mathrm{H}-327$ data where possible. The irradiation data, in most cases, parallel the data obtained on unirradiated material.

\subsubsection{Dimensional Changes}

The irradiation-induced dimensional changes of the candidate graphites have been measured in a series of irradiation experiments, the most recent one being capsule OG-1. There were 346 parallel and 261 perpendicular H-451 specimens, 35 parallel and 35 perpendicular H-429 specimens, 195 parallel and 123 perpendicular H-327 specimens, and 45 parallel and 45 perpendicular $P_{3}$ JHAN specimens in capsule $O G-1$. All of the $H-451$ and 252 of the H-327 specimens were irradiated for the first time in OG-1. All of the $H-429$ specimens along with the remainder of the $H-327$ specimens had been previously irradiated in capsules at BNWL.

The new dimensional change data on $\mathrm{H}-451$ and $\mathrm{H}-429$ are plotted as a function of neutron fluence in Figs, $6-3$ and 6-4. The data for $H-451$ and H-429 were combined $(H-451 / H-429)$ to provide data to fluences of about $6 \times 10^{21} \mathrm{n} / \mathrm{cm}^{2}$. The new $\mathrm{H}-327$ data from capsule OG-1 are given in the Appendix, Tables A-16 and A-17. Comparative dimensional change curves of $\mathrm{H}-327$ versus $\mathrm{H}-451 / \mathrm{H}-429$ are shown in $\mathrm{Fig}$. 6-5. These curves were computer calculated from a least-squares fit of the data. The H-451/H-429 data were extrapolated to $8 \times 10^{21} \mathrm{n} / \mathrm{cm}^{2}$. The mean dimensional change observed in virgin $\mathrm{H}-451$ and $\mathrm{H}-327$ specimens irradiated side by side in capsule $\mathrm{OG}-1$ are given in Table $6-4$. 


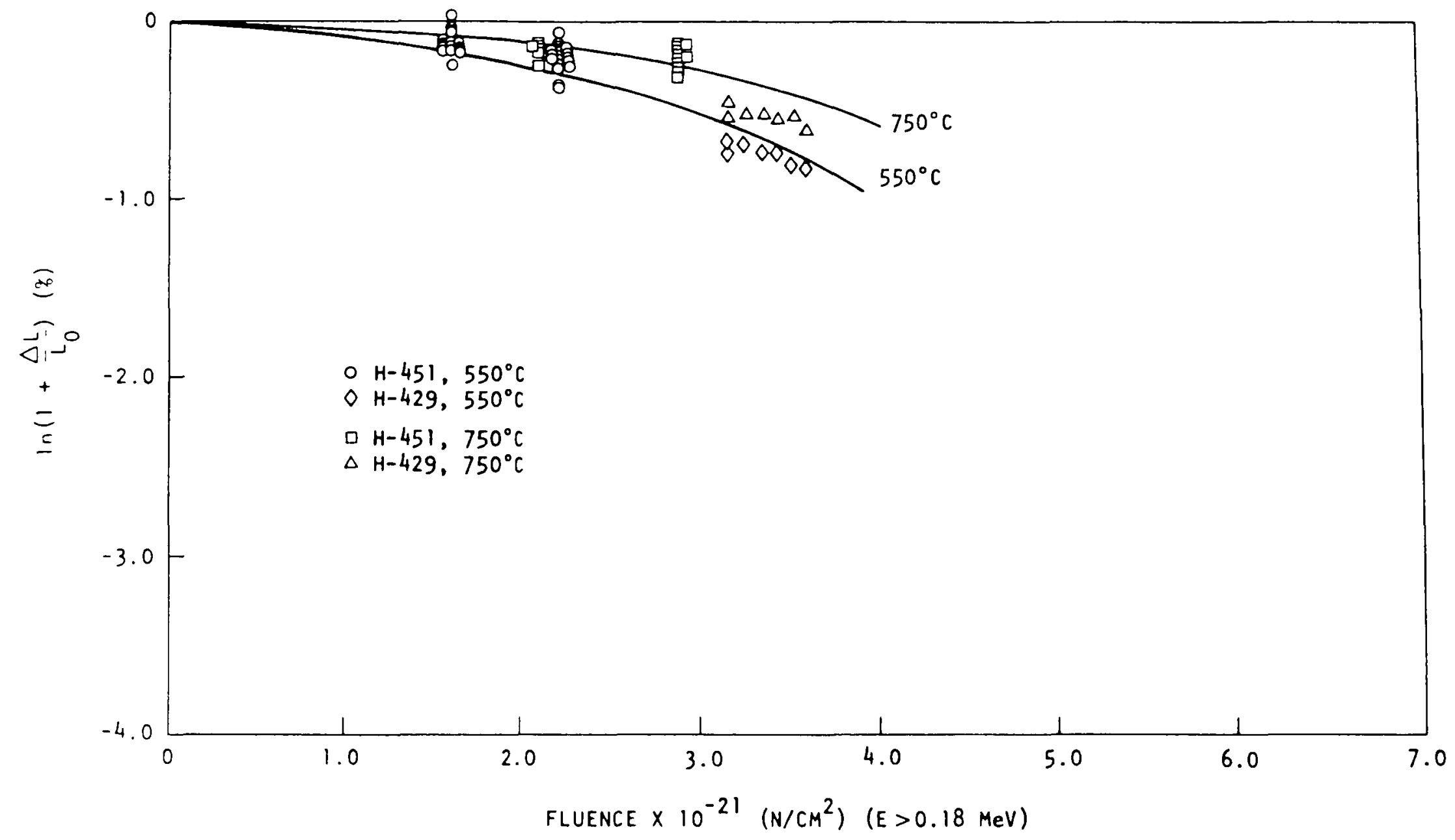

Fig. 6-3. Dimensional changes of near-isotropic graphites $\mathrm{H}-451 / \mathrm{H}-429$ in the parallel direction: (a) $550^{\circ}$ and $750^{\circ} \mathrm{C}$ 


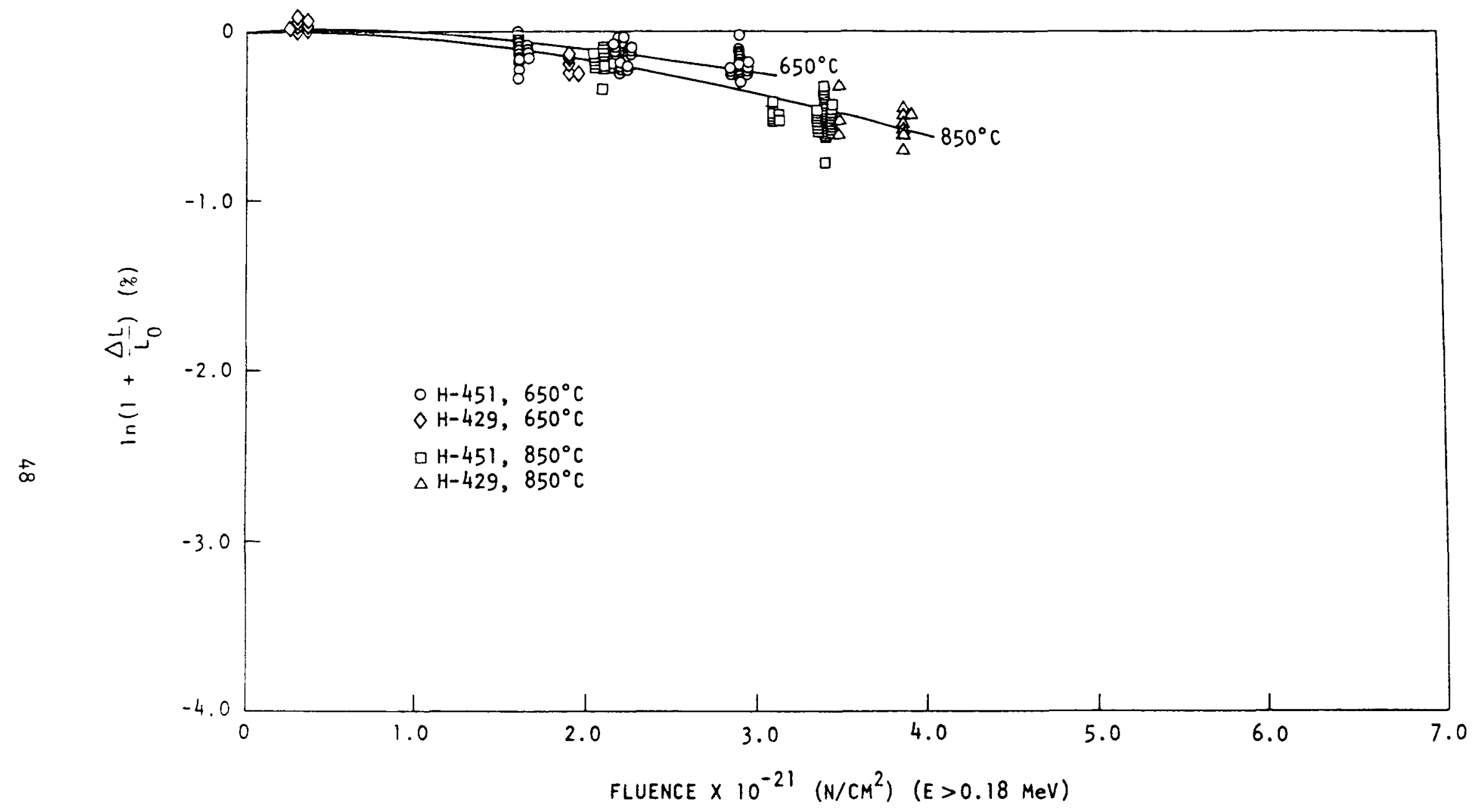

Fig. 6-3. Dimensional changes of near-isotropic graphites $\mathrm{H}-451 / \mathrm{H}-429$ in the parallel direction: (b) $650^{\circ}$ and $850^{\circ} \mathrm{C}$ 


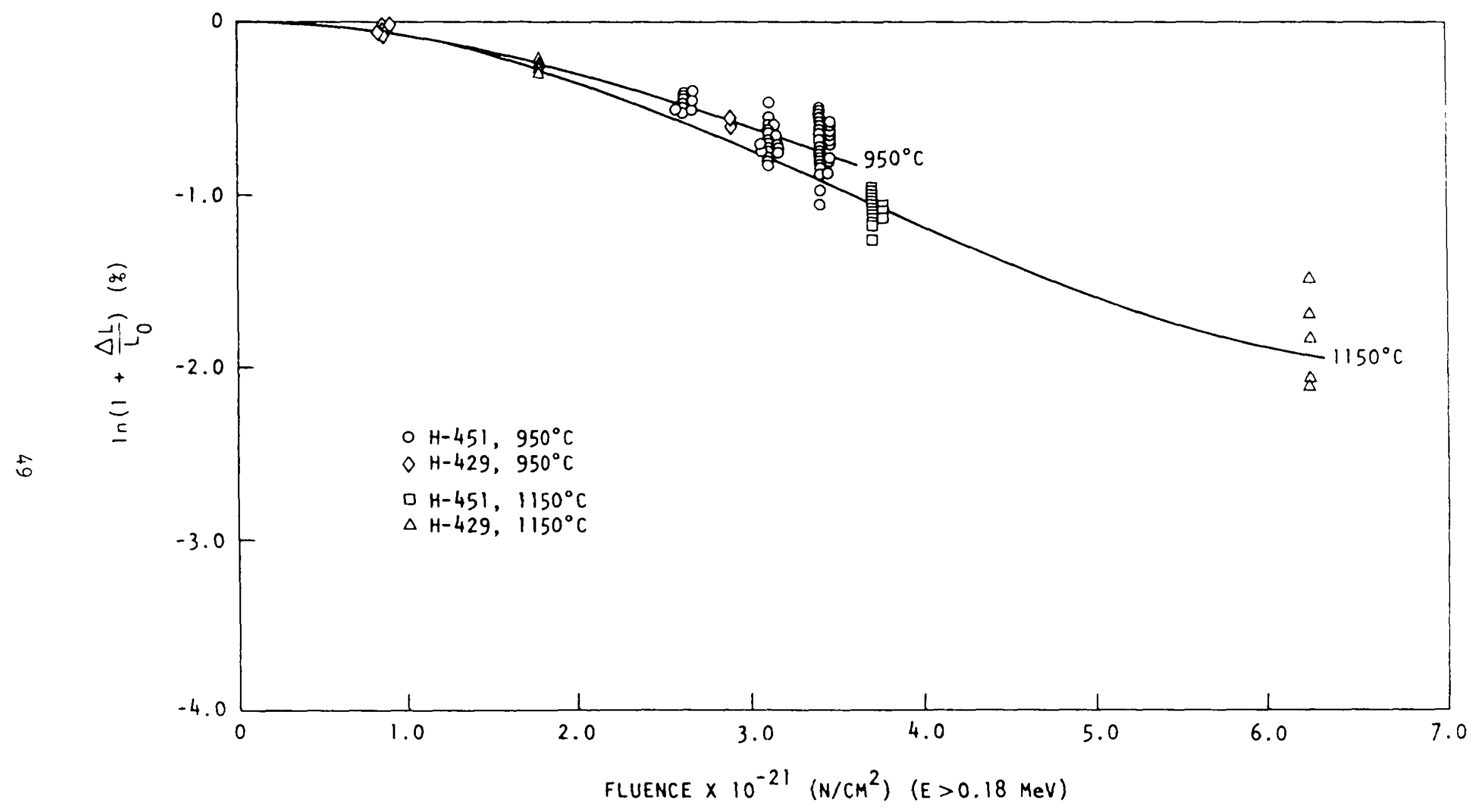

FIg. 6-3. Dimensional changes of near-isotropic graphites $\mathrm{H}-451 / \mathrm{H}-429$ in the parallel direction: (c) $950^{\circ}$ and $1150^{\circ} \mathrm{C}$ 


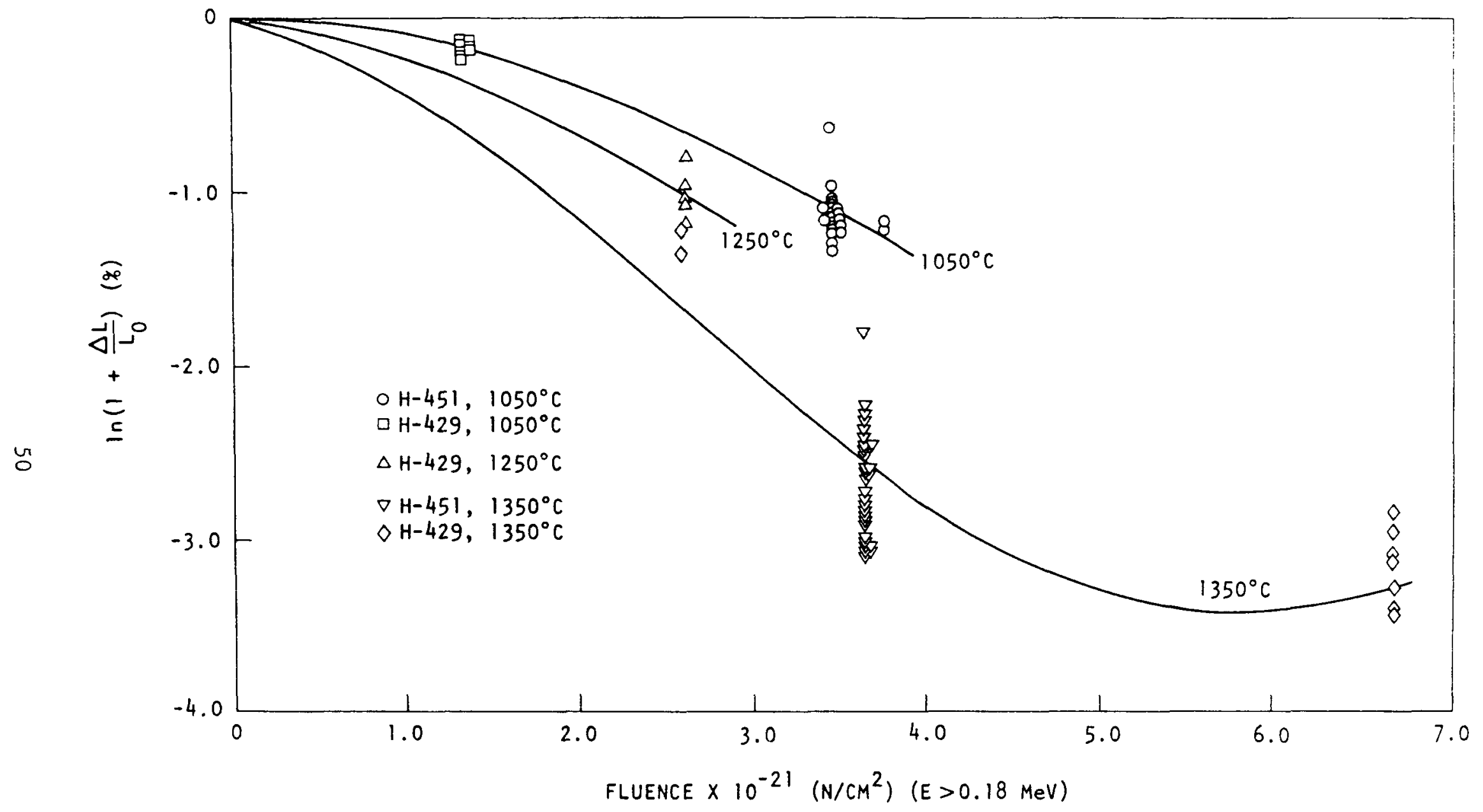

Fig. 6-3. Dimensional changes of near-isotropic graphites $\mathrm{H}-451 / \mathrm{H}-429$ in the parallel direction: (d) $1050^{\circ}, 1250^{\circ}$, and $1350^{\circ} \mathrm{C}$ 


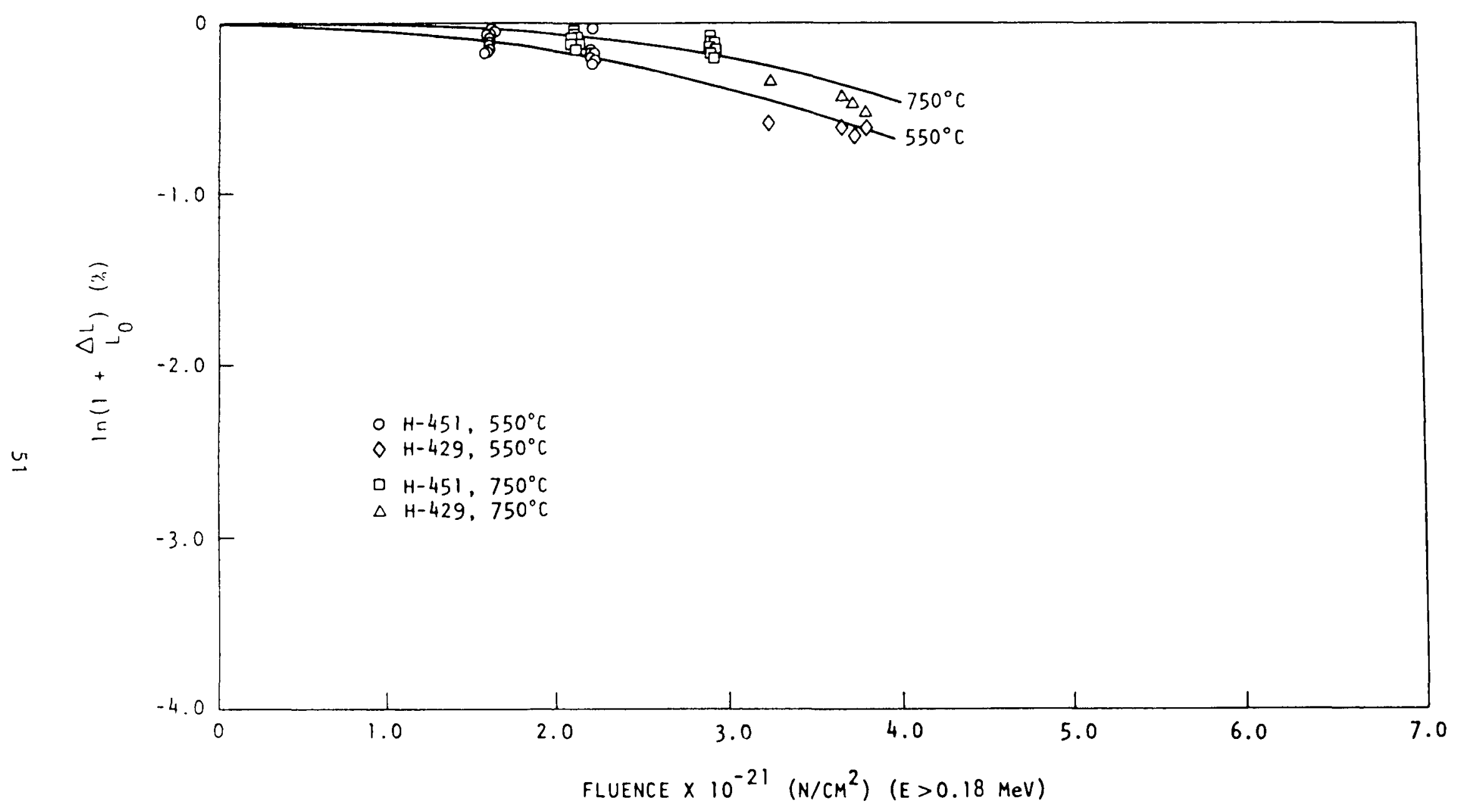

Fig. 6-4. Dimensional changes of near-isotropic graphites $\mathrm{H}-451 / \mathrm{H}-429$ in the perpendicular direction: (a) $550^{\circ}$ and $750^{\circ} \mathrm{C}$ 


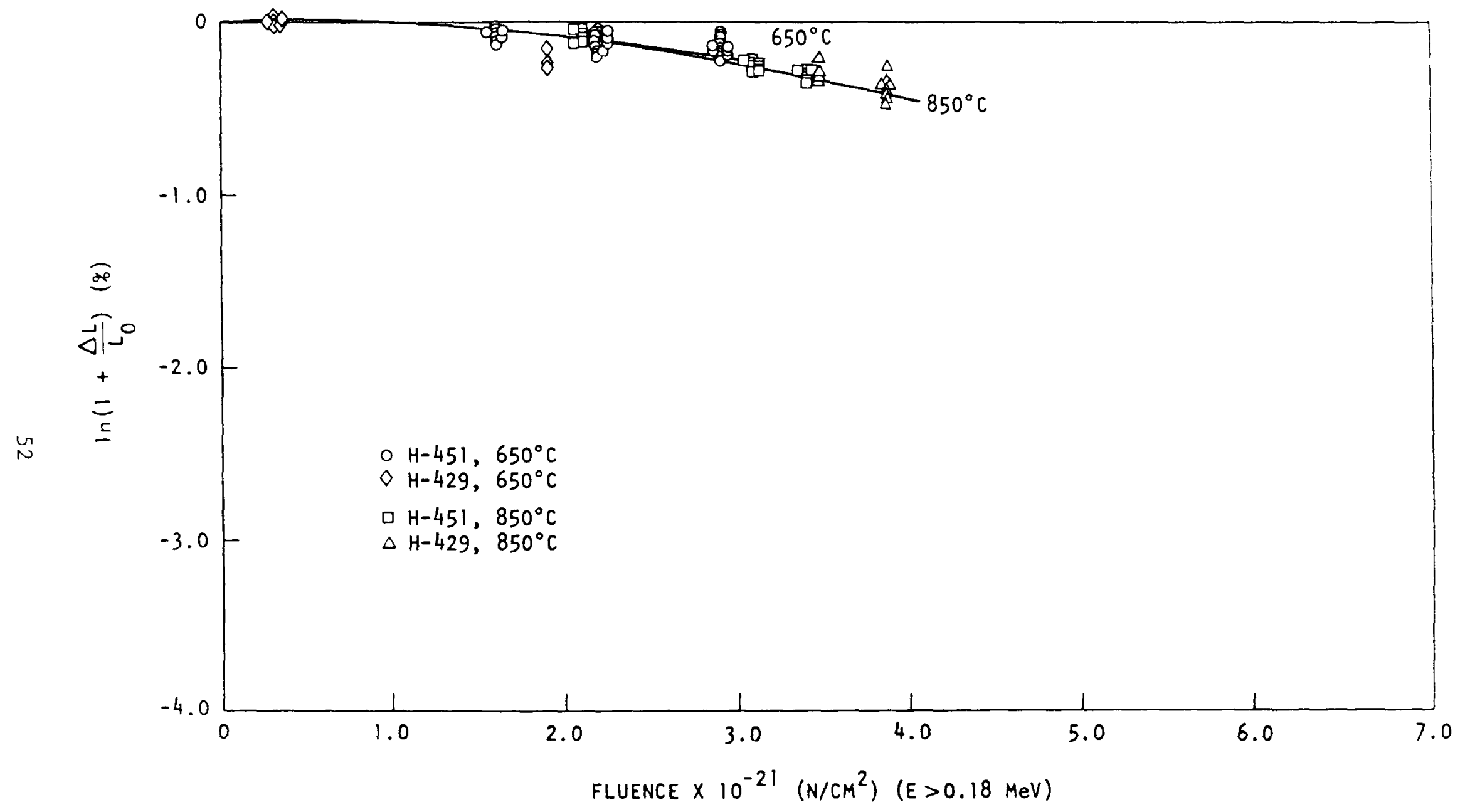

Fig. 6-4. Dimensional changes of near-isotropic graphites $\mathrm{H}-451 / \mathrm{H}-429$ in the perpendicular direction: (b) $650^{\circ}$ and $850^{\circ} \mathrm{C}$ 


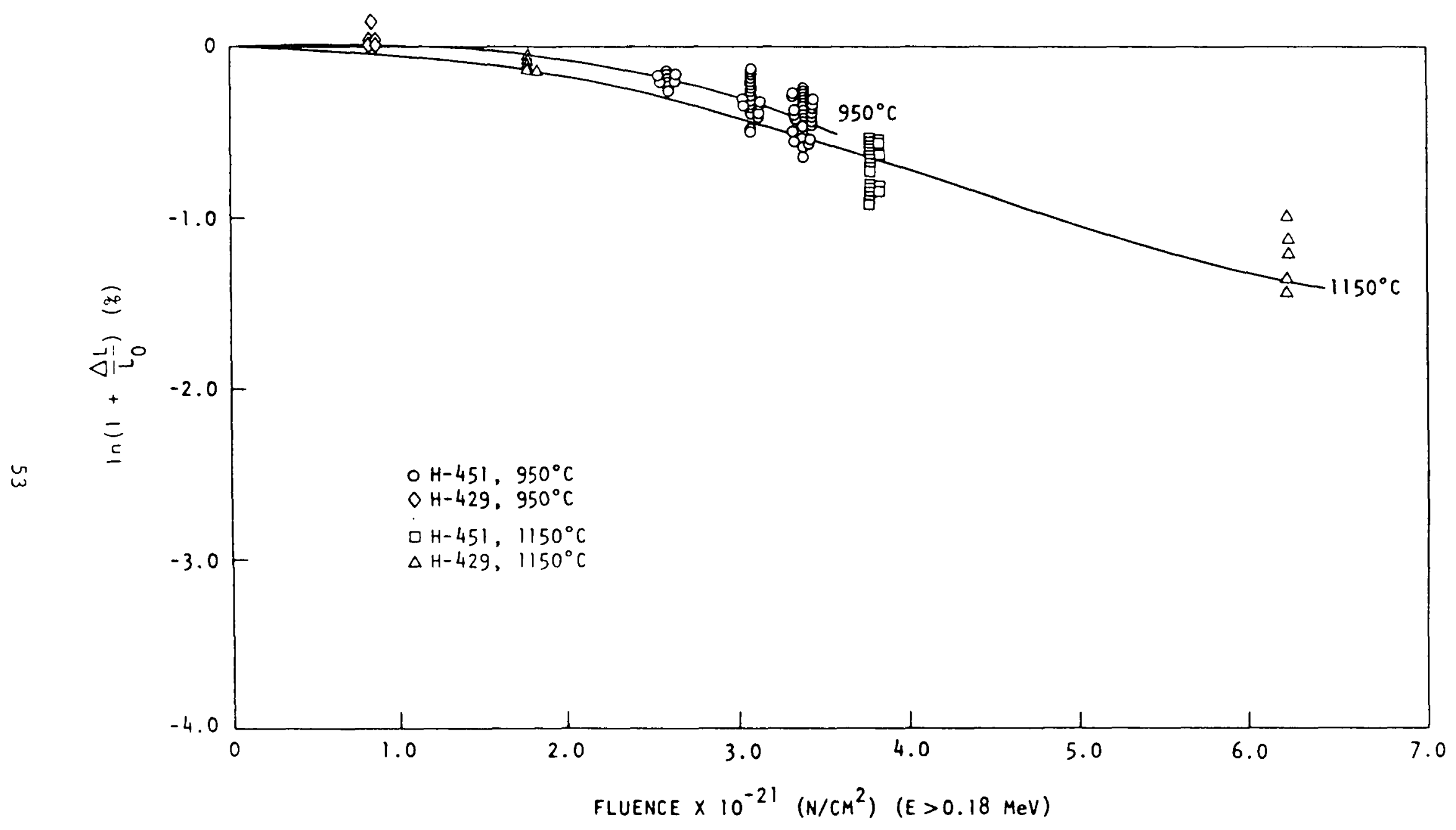

Fig. 6-4. Dimensional changes of near-isotropic graphites $\mathrm{H}-451 / \mathrm{H}-429$ in the perpendicular direction: (c) $950^{\circ}$ and $1150^{\circ} \mathrm{C}$ 


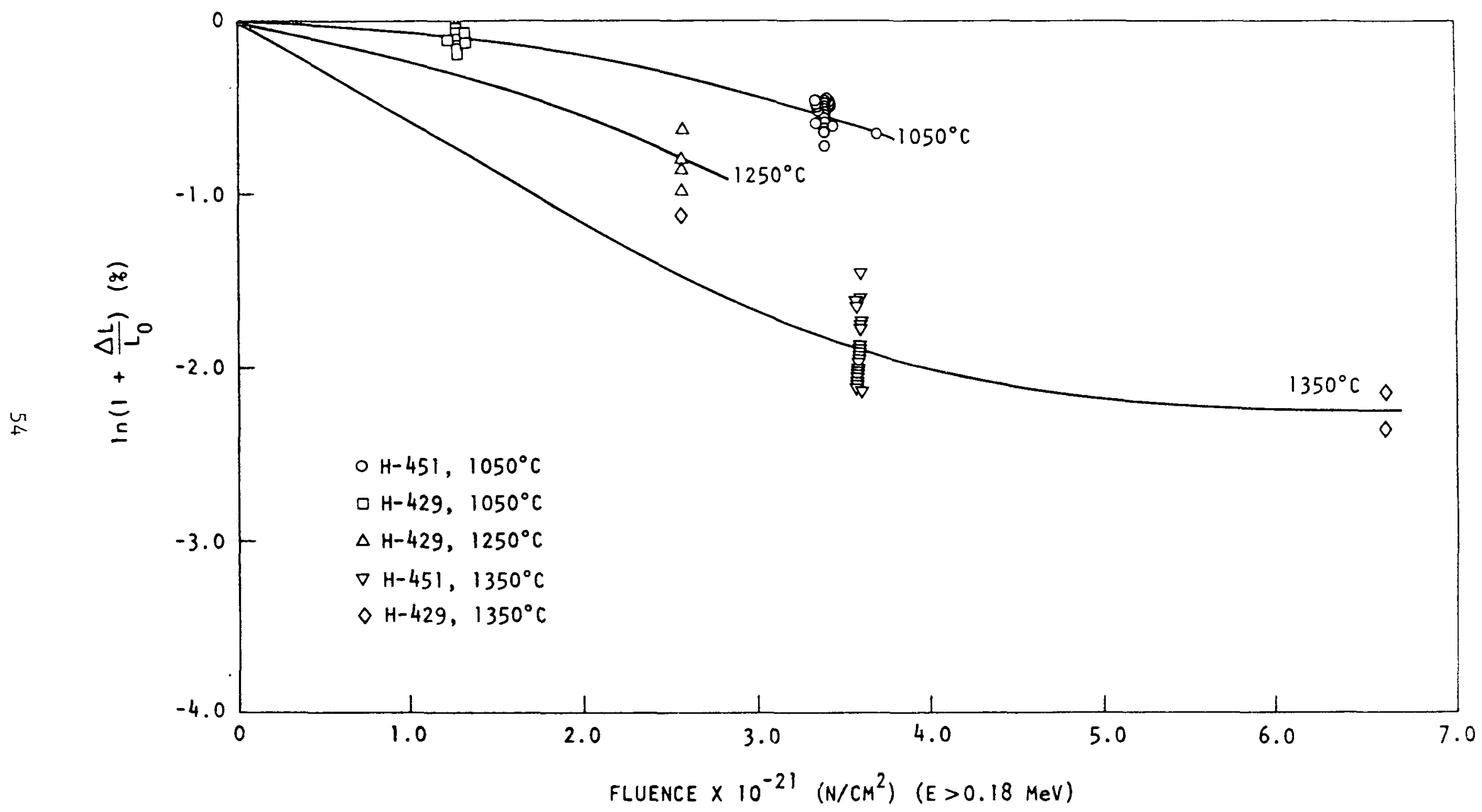

Fig. 6-4. Dimensional changes of near-isotropic graphites $\mathrm{H}-451 / \mathrm{H}-429$ in the perpendicular direction: (d) $1050^{\circ}, 1250^{\circ}$, and $1350^{\circ} \mathrm{C}$ 


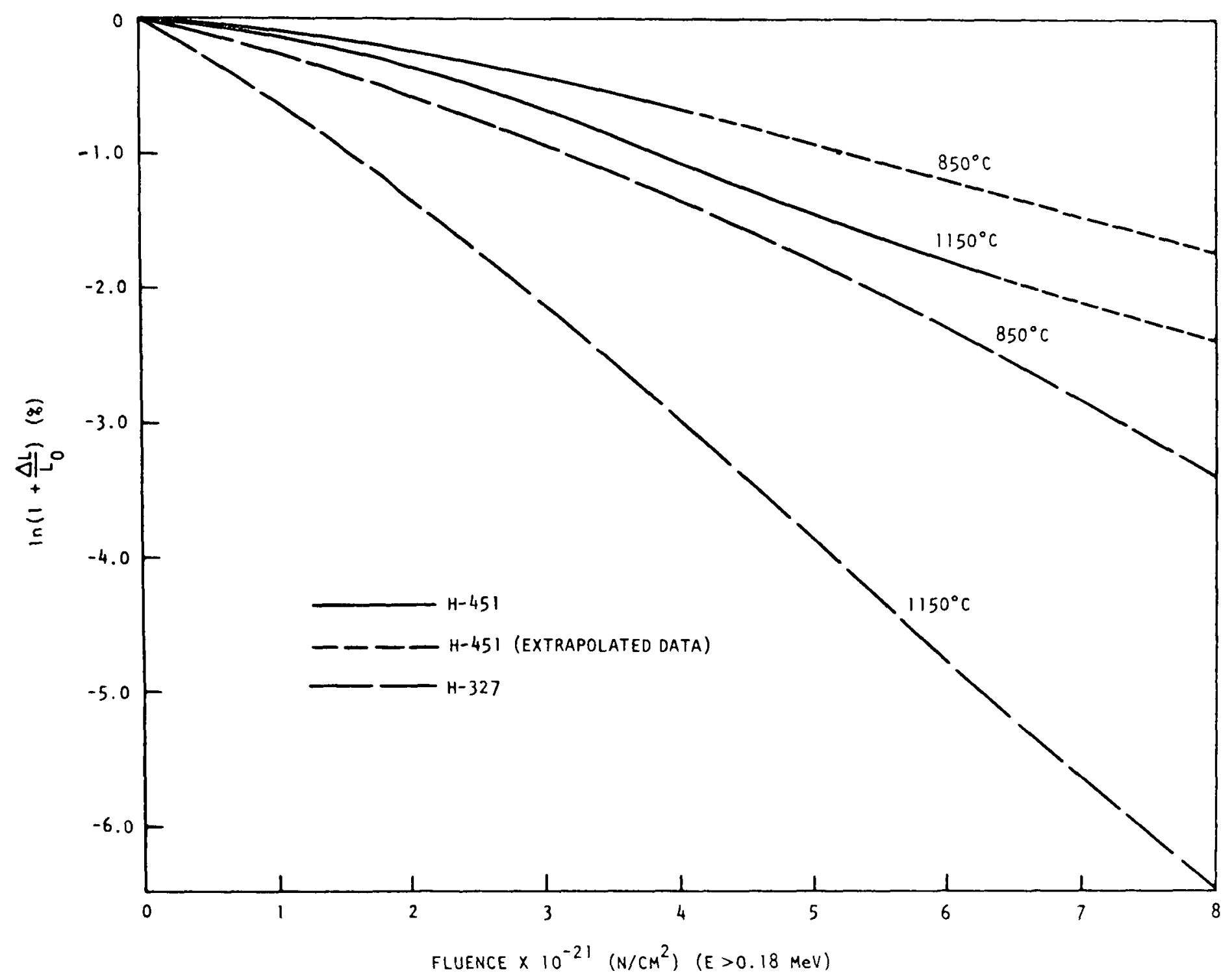

Fig. 6-5. Comparison of dimensional changes of $H-327$ and $H-451 / H-429$ : (a) paralle1 


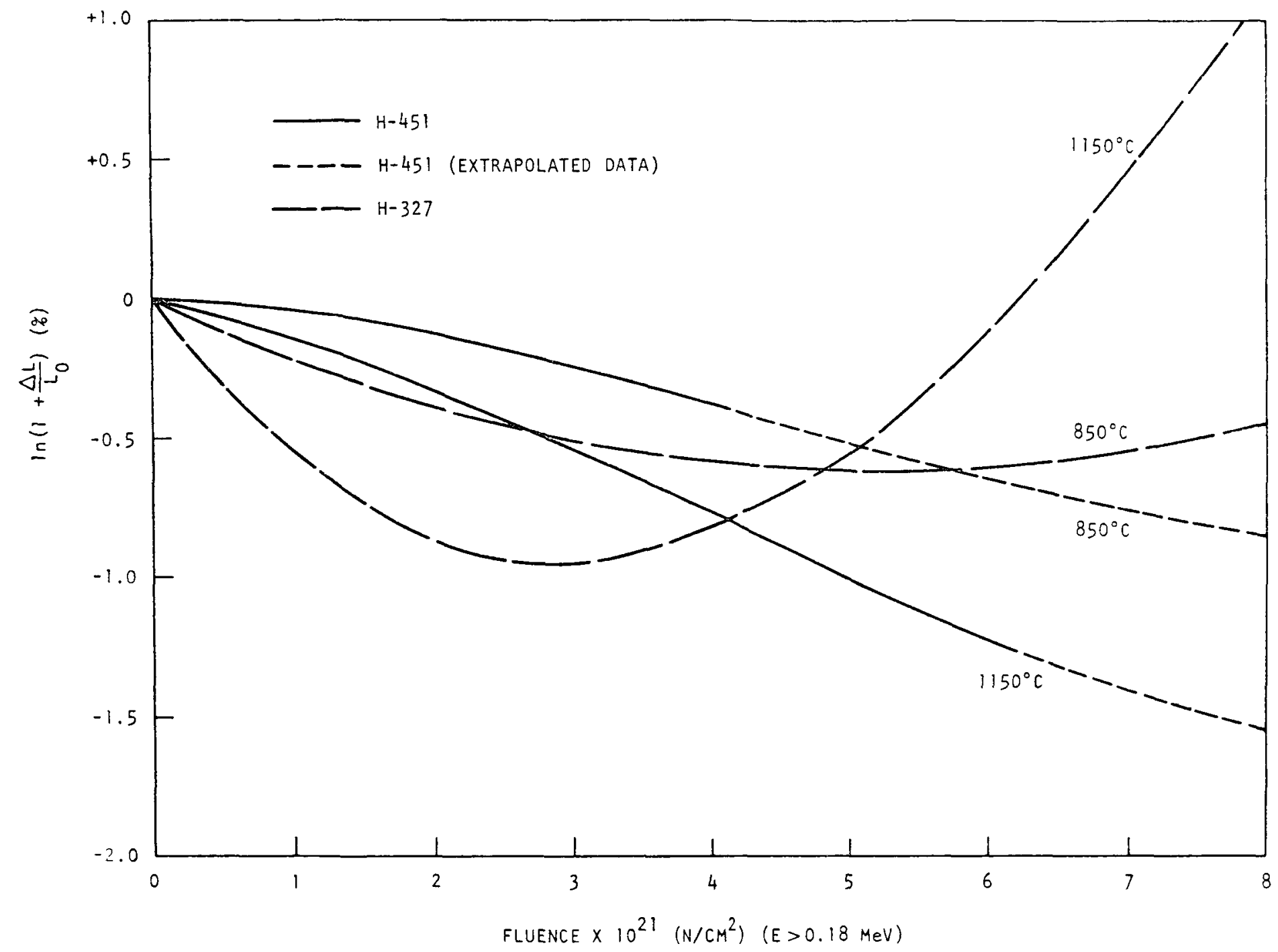

Fig. 6-5. Comparison of dimensional changes of H-327 and H-451/H-429: (b) perpendicular 
TABLE 6-4

COMPARISON OF MEAN IRRADIATION-INDUCED DIMENSIONAL CHANGES

IN H-327 AND H-451 GRAPHITES IRRADIATED IN OG-1

\begin{tabular}{|c|c|c|c|c|c|c|}
\hline \multirow[b]{3}{*}{ Crucible } & \multirow{3}{*}{$\begin{array}{c}\text { Fluence } \mathrm{x} \\
10^{-21}\left(\mathrm{n} / \mathrm{cm}^{2}\right) \\
(\mathrm{E}>0.18 \mathrm{MeV})\end{array}$} & \multirow{3}{*}{$\begin{array}{l}\text { Irradiation } \\
\text { Temperature } \\
\left({ }^{\circ} \mathrm{C}\right)\end{array}$} & \multicolumn{4}{|c|}{ Dimensional Change $\ln \left(1+\underset{\mathrm{L}_{0}}{\stackrel{\Delta \mathrm{L}}{\longrightarrow}}\right.$} \\
\hline & & & \multicolumn{2}{|c|}{ Parallel } & \multicolumn{2}{|c|}{ Perpendicular } \\
\hline & & & $\mathrm{H}-327$ & $\mathrm{H}-451$ & $\mathrm{H}-327$ & $\mathrm{H}-451$ \\
\hline 1 & 2.2 & $\begin{array}{l}645 \\
615 \\
560\end{array}$ & $\begin{array}{l}-0.14 \\
-0.19 \\
-0.17\end{array}$ & $\begin{array}{l}-0.10 \\
-0.16 \\
-0.20\end{array}$ & $\begin{array}{l}-0.10 \\
-0.15 \\
-0.19\end{array}$ & $\begin{array}{l}-0.08 \\
-0.13 \\
-0.16\end{array}$ \\
\hline 2 & 2.9 & $\begin{array}{l}740 \\
690 \\
610\end{array}$ & $\begin{array}{l}-0.22 \\
-0.21 \\
-0.28\end{array}$ & $\begin{array}{l}-0.17 \\
-0.20 \\
-0.22\end{array}$ & $\begin{array}{l}-0.13 \\
-0.22 \\
-0.23\end{array}$ & $\begin{array}{l}-0.11 \\
-0.15 \\
-0.15\end{array}$ \\
\hline 3 & 3.4 & $\begin{array}{l}945 \\
890\end{array}$ & -0.59 & $-\overline{-}-\overline{49}$ & $\begin{array}{c}-0.46 \\
--\end{array}$ & $\begin{array}{c}-0.37 \\
--\end{array}$ \\
\hline 4 & 3.7 & $\begin{array}{l}1110 \\
1040\end{array}$ & $\begin{array}{l}-1.82 \\
-1.36\end{array}$ & $\begin{array}{l}-0.71 \\
-0.80\end{array}$ & $\begin{array}{l}-- \\
--\end{array}$ & -- \\
\hline 6 & 3.4 & $\begin{array}{r}1020 \\
940\end{array}$ & $\begin{array}{l}-1.22 \\
-0.79\end{array}$ & $\begin{array}{l}-0.90 \\
-0.62\end{array}$ & $\begin{array}{l}-0.46 \\
-0.38\end{array}$ & $\begin{array}{l}-0.49 \\
-0.32\end{array}$ \\
\hline 7 & 3.1 & $\begin{array}{l}990 \\
980 \\
885\end{array}$ & $\begin{array}{l}-1.09 \\
-0.99 \\
-0.74\end{array}$ & $\begin{array}{l}-0.81 \\
-0.47 \\
-0.50\end{array}$ & $\begin{array}{l}-0.30 \\
-0.28 \\
-0.34\end{array}$ & $\begin{array}{l}-0.41 \\
-0.20 \\
-0.26\end{array}$ \\
\hline 8 & 2.6 & $\begin{array}{l}930 \\
920 \\
835\end{array}$ & $\begin{array}{l}-0.60 \\
-0.53 \\
-0.32\end{array}$ & $\begin{array}{l}-0.54 \\
-0.47 \\
-0.33\end{array}$ & $\begin{array}{l}-0.25 \\
-0.15 \\
-0.11\end{array}$ & $\begin{array}{l}-0.18 \\
-0.20 \\
-0.13\end{array}$ \\
\hline 9 & 2.1 & $\begin{array}{l}810 \\
750\end{array}$ & $\begin{array}{l}-0.12 \\
-0.13\end{array}$ & $\begin{array}{l}-0.18 \\
-0.15\end{array}$ & $\begin{array}{l}-- \\
--\end{array}$ & - \\
\hline 10 & 1.6 & $\begin{array}{l}650 \\
645 \\
595\end{array}$ & $\begin{array}{l}-0.06 \\
-0.13 \\
-0.15\end{array}$ & $\begin{array}{l}-0.06 \\
-0.09 \\
-0.12\end{array}$ & $\begin{array}{l}-0.06 \\
-0.07 \\
-0.06\end{array}$ & $\begin{array}{l}-0.06 \\
-0.06 \\
-0.09\end{array}$ \\
\hline
\end{tabular}


In the perpendicular direction the needle-coke graphite undergoes initial contraction followed by expansion which can lead to a total net expansion at high fluences and temperatures. The near-isotropic graphite contracts more slowly initially than the needle-coke graphite and the shrinkage passes through its minimum at neutron fluences where the needlecoke graphite has already expanded past its original dimensions. The data in Table 6-4 show $\mathrm{H}-327$ contracts at a higher rate in the parallel direction than H-451. This effect is particularly evident at higher fluences and temperatures. The difference in behavior between the two graphites in the perpendicular direction is less marked because $\mathrm{H}-327$ is nearing turnaround at the higher temperatures.

These data indicate the $\mathrm{H}-451$ graphite is behaving dimensionally much like the Gilsocoke graphites shown in Figs. 3-4 and 3-9. It is concluded that near-isotropic graphites will provide much improved dimensional stability compared to needle-coke graphites at high temperatures and fluences and its use for core components will permit longer residence time in large HTGRs.

\subsubsection{Thermal Expansivity}

Thermal expansivity measurements were made on 72 samples of irradiated graphite from capsule $\mathrm{OC}-1$. Measurements were made between room temperature and $100^{\circ} \mathrm{C}$ less than the irradiation temperature. The samples were cylinders measuring $0.2 \mathrm{in.}$ in diameter by $0.45 \mathrm{in.}$ long. Graphites included H-327 (production-grade needle coke), H-451 (preproduction near-isotropic petroleum coke), and H-429 (prototype of H-451). The H-429 samples and some of the H-327 samples had been previously irradiated in capsule GEH-13-422 (Ref. 23), thus providing high-fluence data on a near-isotropic petroleumcoke-based material.

The mean expansivities between room temperature and $500^{\circ} \mathrm{C}$ are listed in the Appendix in Tables A-18 and A-19. The expansivity of H-327 graphite is plotted as a function of fast neutron fluence in Fig. 6-6, and that of 


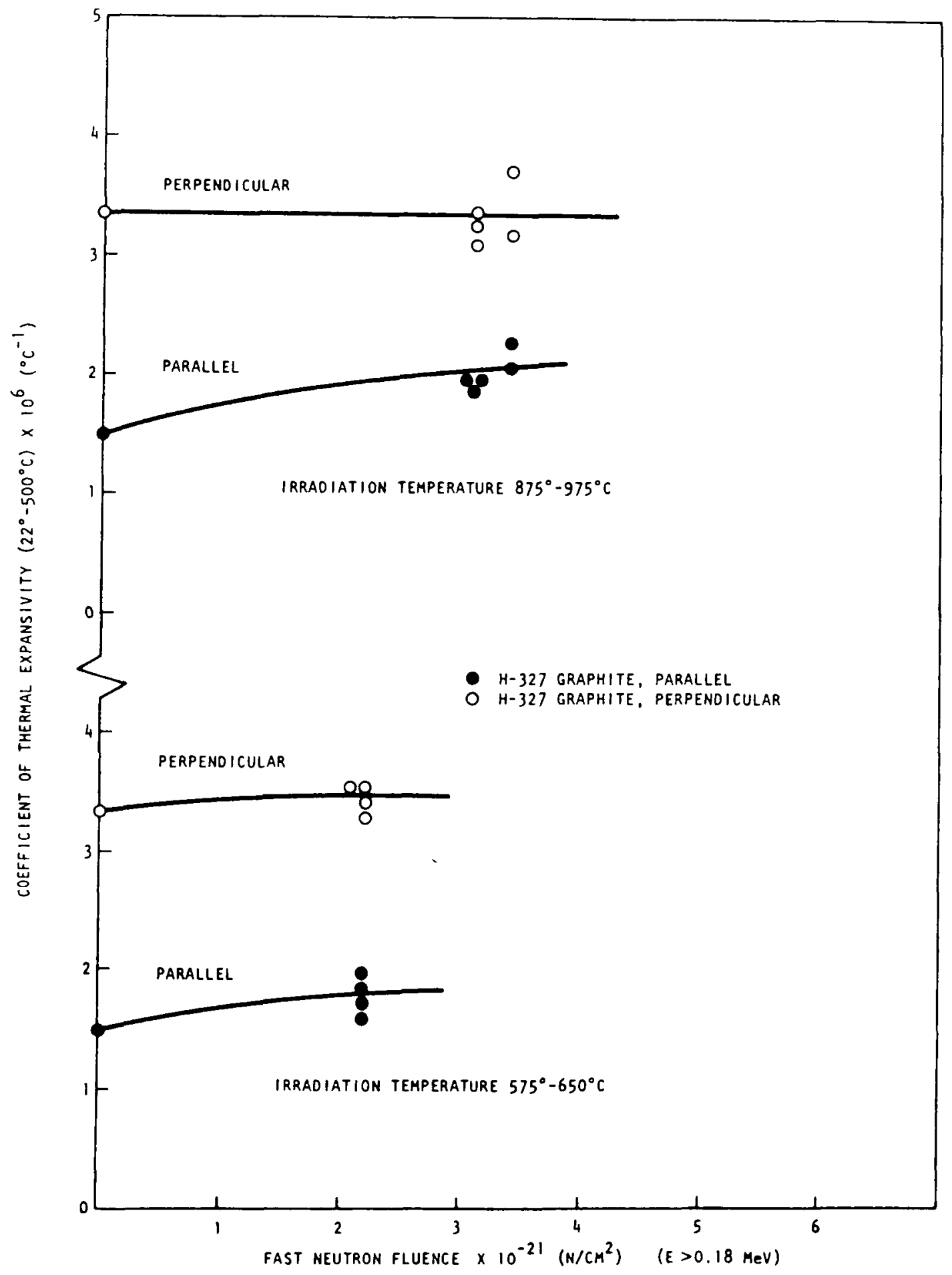

Fig. 6-6. Thermal expansivity of $\mathrm{H}-327$ graphite as a function of fast neutron fluence at $875^{\circ}$ to $975^{\circ} \mathrm{C}$ and $575^{\circ}$ to $650^{\circ} \mathrm{C}$. 
H-429/H-451 is shown in Figs. $6-7$ and 6-8. The thermal expansivity of H-327 graphite increased by about $0.5 \times 10^{-6}{ }^{\circ} \mathrm{C}^{-1}$ in the parallel direction after a fluence of 2 to $3 \times 10^{21} \mathrm{n} / \mathrm{cm}^{2}$ (E $>0.18 \mathrm{MeV}$ ) at $575^{\circ}$ to $650^{\circ} \mathrm{C}$ and $875^{\circ}$ to $975^{\circ} \mathrm{C}$, but remained unchanged in the perpendicular direction. The irradiation-induced changes in the thermal expansivity of $\mathrm{H}-429 / \mathrm{H}-451$ (Figs. 6-7 and 6-8) were quite sma11. At $650^{\circ} \mathrm{C}$ and $850^{\circ} \mathrm{C}$ the expansivity increased by about $0.5 \times 10^{-6}{ }^{\circ} \mathrm{C}^{-1}$ in both the parallel and perpendicular directions for a fluence of $\sim 2 \times 10^{21} \mathrm{n} / \mathrm{cm}^{2}$ ( $E>0.18 \mathrm{MeV}$ ). At higher temperatures the changes were smaller; there was some indication of a net decrease in expansivity after irradiation to $6.6 \times 10^{21} \mathrm{n} / \mathrm{cm}^{2}$ at $1370^{\circ}$ to $1500^{\circ} \mathrm{C}$ (Fig. 6-7). These changes are much less than those occurring in Gilsocoke-based graphites, whose thermal expansivities first increase and later decrease to about half their preirradiation value at around $5 \times 10^{21}$ $\mathrm{n} / \mathrm{cm}^{2}(\mathrm{E}>0.18 \mathrm{MeV})$ for temperatures in the vicinity of $1000^{\circ} \mathrm{C}$.

\subsubsection{Thermal Conductivity}

Thermal diffusivity measurements were made on 51 discs $(0.45$ in. in diameter by 0.05 in. thick) of $\mathrm{H}-327$ and $\mathrm{H}-451$ graphites after irradiation in the $O G-1$ capsule. The $H-327$ discs had previously been irradiated in capsule GEH-13-422 (Ref. 13). Thermal diffusivity measurements were made by the heat-pulse method (ASTM Method of Test C-741) and the thermal diffusivity values were converted to thermal conductivities by multiplying by density and literature values for the heat capacity of graphite. About half the samples were tested at room temperature only, and half were measured with the temperature increasing in $100^{\circ} \mathrm{C}$ steps to $100^{\circ} \mathrm{C}$ less than the irradiation temperature or to $800^{\circ} \mathrm{C}$, whichever was lower.

The results are listed in the Appendix, Tables A-20 and A-21. The conductivity at the irradiation temperature was estimated by extrapolating the data points, assuming a temperature dependence curve appropriate for irradiated graphite (Ref. 24). The mean values for the conductivity at the irradiation temperature are summarized in Table A-22. Because of 1 ts high degree of orientation, the H-327 graphite had a higher conductivity 


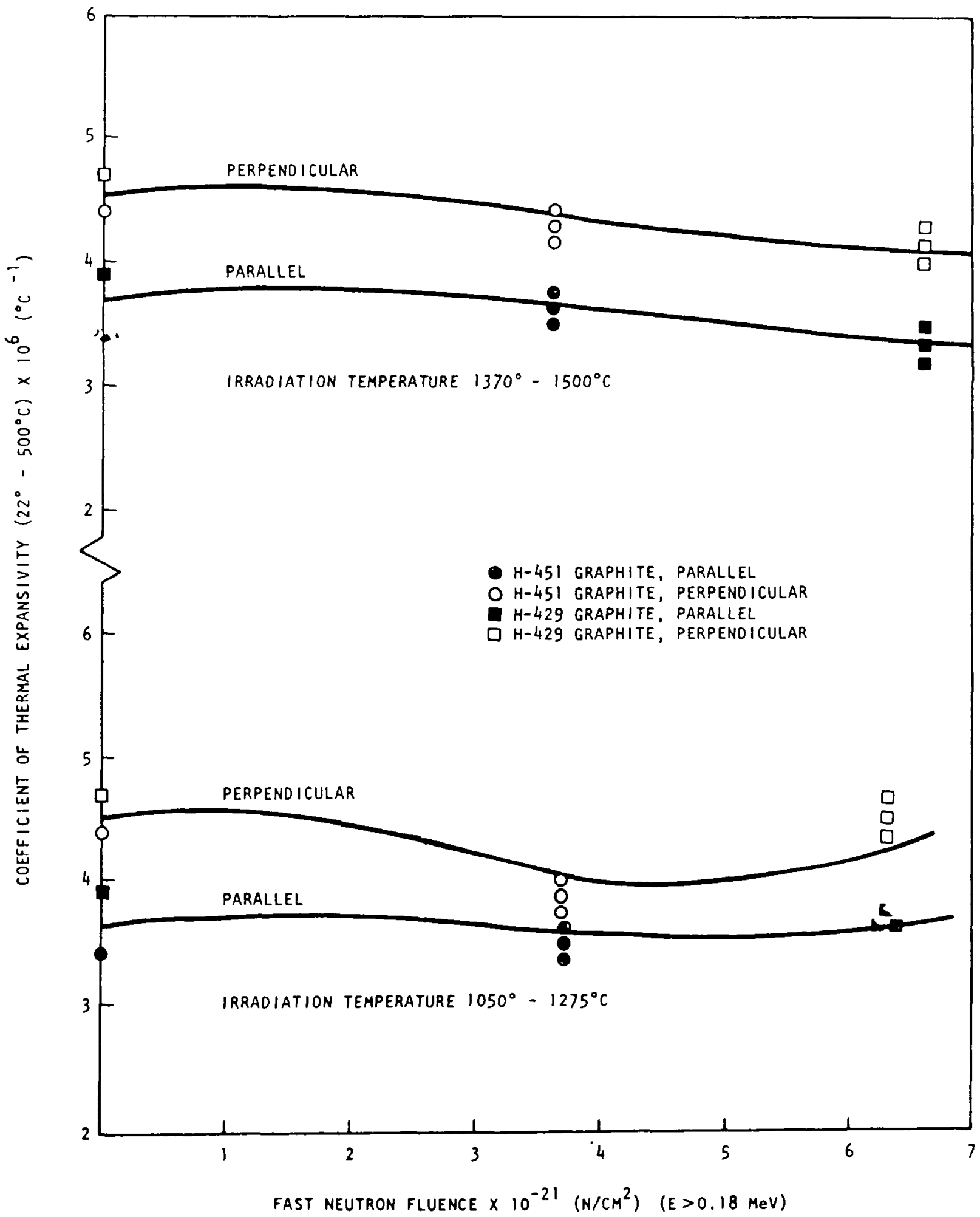

Fig. 6-7. Thermal expansivity of $\mathrm{H}-451 / \mathrm{H}-429$ graphites as a function of fast neutron fluence at $1370^{\circ}$ to $1500^{\circ} \mathrm{C}$ and $1050^{\circ}$ to $1275^{\circ} \mathrm{C}$ 


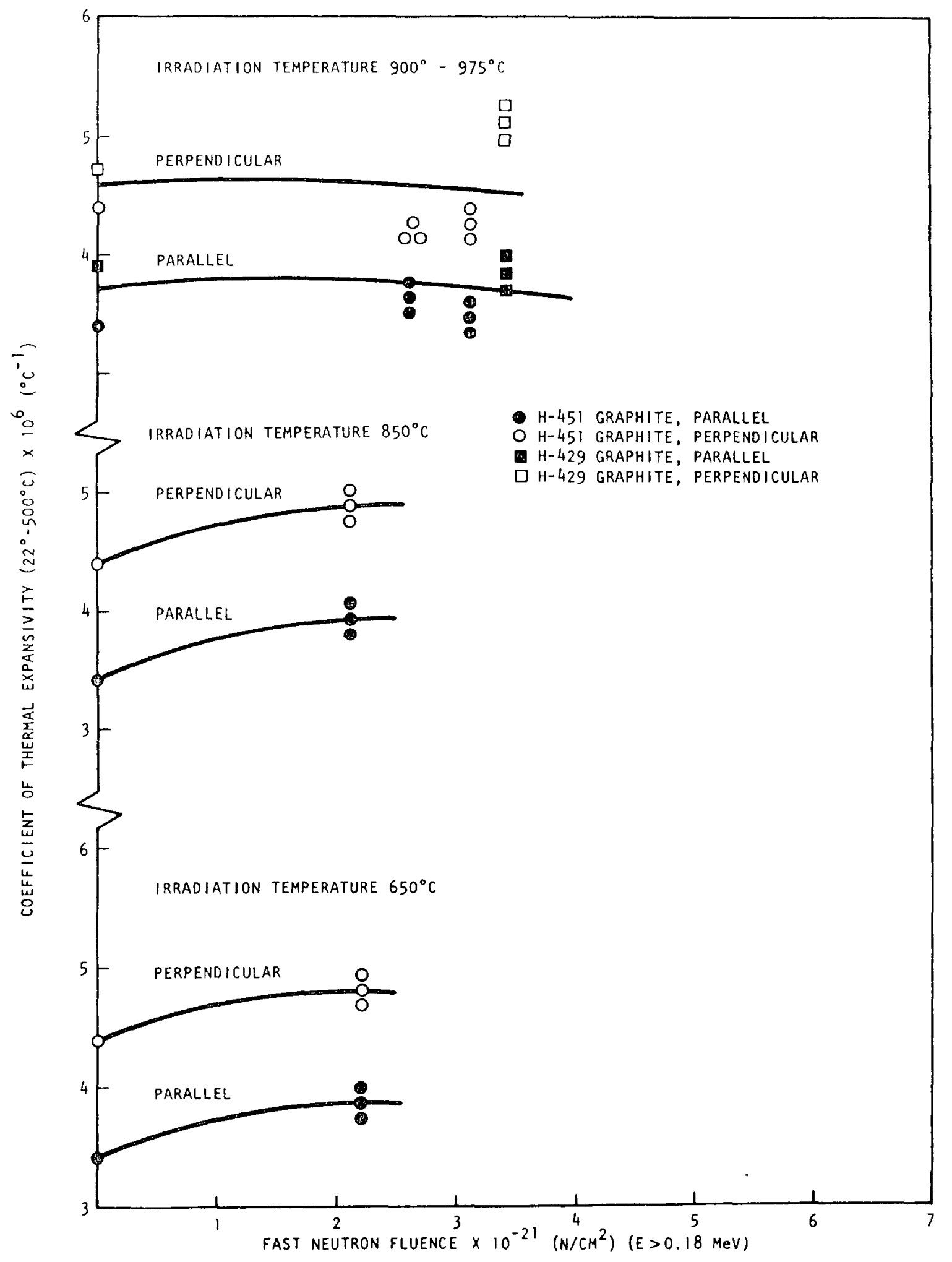

Fig. 6-8. Thermal expansivity of $\mathrm{H}-451 / \mathrm{H}-429$ graphites as a function of fast neutron fluence at $900^{\circ}$ to $975^{\circ} \mathrm{C}$, $850^{\circ} \mathrm{C}$, and $650^{\circ} \mathrm{C}$ 
parallel to extrusion than perpendicular to extrusion. For H-451 graphite the difference was much less marked. At $600^{\circ}$ and $900^{\circ} \mathrm{C}$ the perpendicular conductivity of irradiated $\mathrm{H}-451$ graphite was considerably greater than that of irradiated $\mathrm{H}-327$ graphite; the $\mathrm{H}-451$ perpendicular conductivity also was slightly higher than $\mathrm{H}-327$ graphite in the parallel direction. The thermal conductivity of irradiated $\mathrm{H}-451$ graphite was in good agreement with curves calculated from the irradiation behavior of Gilsocoke-based graphites (Ref. 24). The comparison is shown in Fig. 6-9.

\subsubsection{Tensile Properties}

Tensile tests were conducted in air at room temperature on 0.25-in.diameter by 0.9 -in.-long cylinders of $\mathrm{H}-327$ and $\mathrm{H}-451$ graphite irradiated in capsule OG-1. Typical stress-strain curves for unirradiated and irradiated $\mathrm{H}-451$ graphite are shown in Fig. 6-10. Because of the inelastic component in the deformation of graphite, the unloading curve does not retrace the initial loading curve but reaches zero load with a positive "permanent set." The second loading curve superimposes on the unloading curve, and beyond the first strain reversal point it forms a continuation of the initial loading curve. Irradiation greatly reduces the inelastic strain component and the stress-strain curve loses much of its curvature, particularly for irradiation at lower temperature (see Fig. 6-10). In the present tests Young's modulus was measured from the 100 to 1000 psi reloading portion of the curve because this represents the effective modulus of a graphite component after its first stress excursion and because its slope is more accurately measured than that of a tangent to the curve at the origin.

The results of the tensile tests are listed in the Appendix, Tables $A-23$ and $A-24$. The tensile data for unirradiated material were obtained from companion samples from the same log locations as the irradiated samples, except in the case of $\mathrm{H}-327$ from the center of the $10 \mathrm{~g}$ where earlier results on 0.5-in.-diameter samples were used (see Table A-23). The changes in strength and Young's modulus with neutron exposure are 


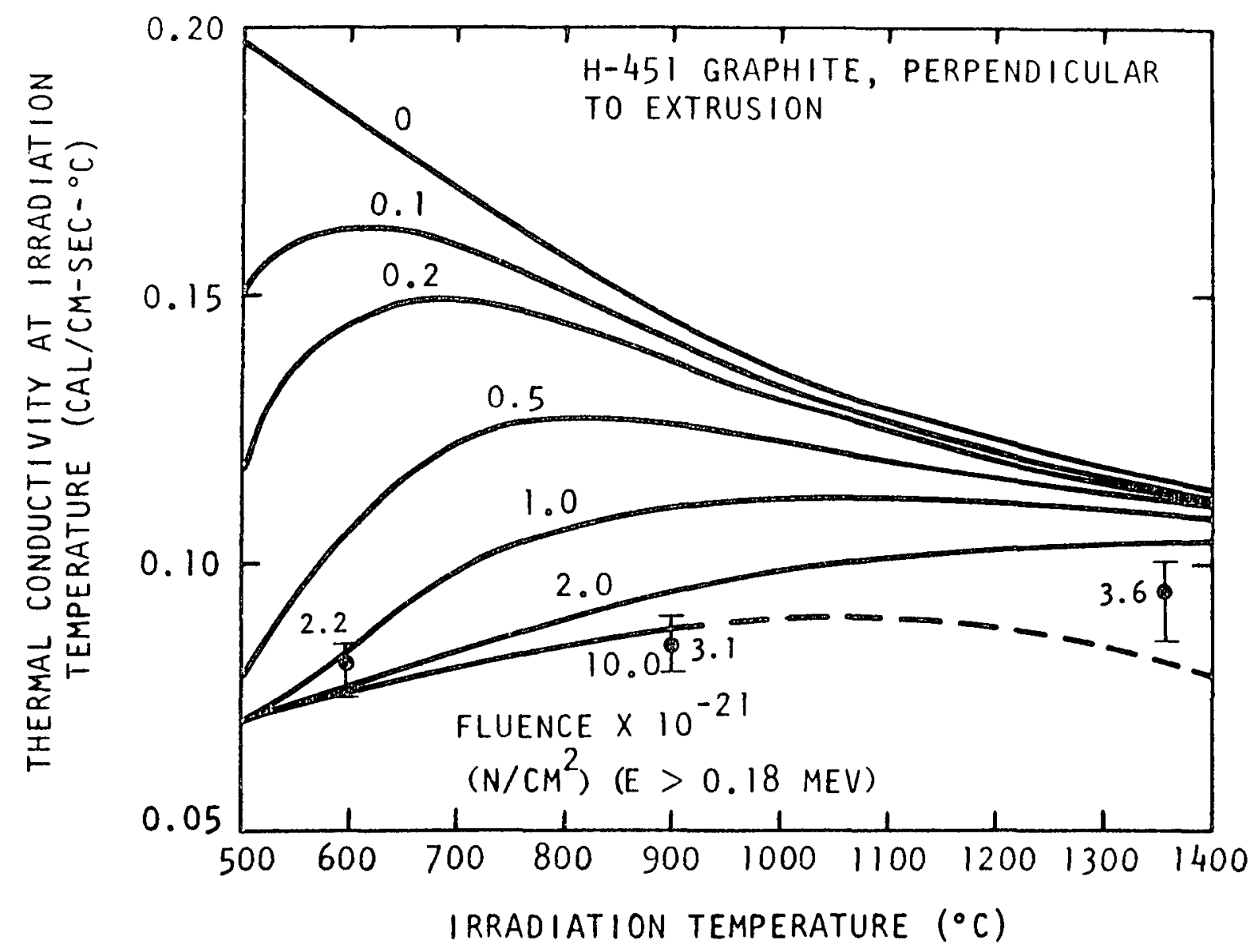

Fig. 6-9. Calculated curves of the thermal conductivity of $H-451$ graphite at the irradiation temperature as a function of irradiation temperature; based on the bahavior of Gilsocoke-based graphites (Ref. 24). Data points are experimental measurements from OG-1 capsule. 

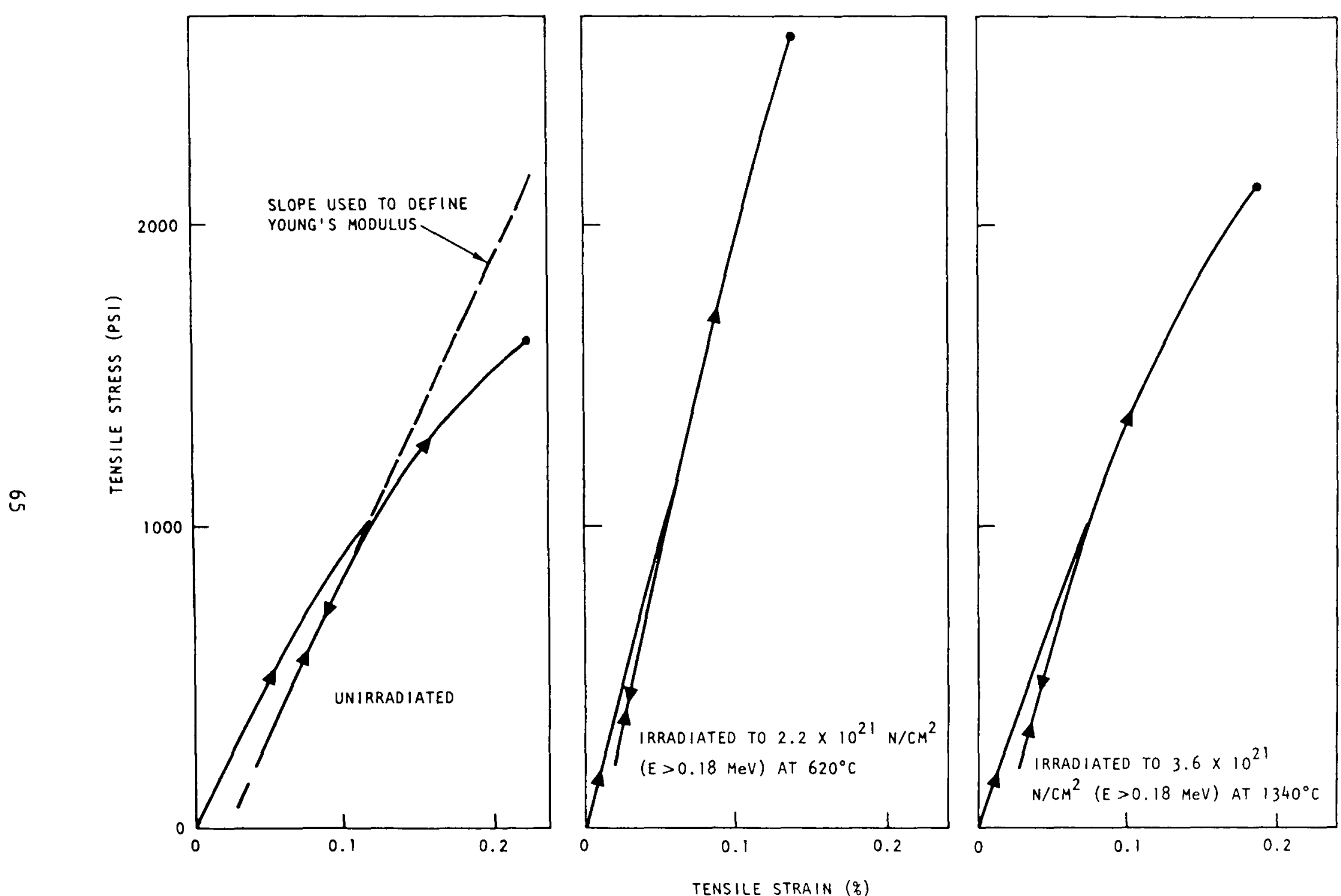

Fig. 6-10. Typical stress-strain curves for unirradiated and irradiated H-451 graphite 
illustrated in Figs. 6-11 through 6-13. The strength and Young's modulus of the paralle1-cut samples of $\mathrm{H}-327$ graphite and both parallel and perpendicular samples of $\mathrm{H}-451$ graphite increased, with a greater increase for lower temperature irradiation than for higher temperature irradiation. The percentage increases in strength were in the range 30 to $60 \%$, while increases in elastic modulus ranged from 60 to $130 \%$. The single group of perpendicular samples of $\mathrm{H}-327$ graphite from the center of the $10 \mathrm{~g}$ showed no change in strength after irradiation, while their elastic modulus doubled. With the possible exception of the perpendicular samples of H-327 graphite, there was no significant change in the scatter of the strength data following irradiation, with the coefficient of variation remaining at about $10 \%$. Average strength values (plus or minus one standard deviation) for material from the center of the $\log$ (the weakest portion) irradiated to 2.6 to $3.4 \times 10^{21} \mathrm{n} / \mathrm{cm}^{2}$ at $860^{\circ}$ to $1080^{\circ} \mathrm{C}$ were:

\begin{tabular}{|c|c|c|}
\hline $\mathrm{H}-327$ & paralle $\perp$ & $2127 \pm 281 \mathrm{psi}$ \\
\hline $\mathrm{H}-327$ & perpendicular & $962 \pm 198 \mathrm{p}$ \\
\hline $\mathrm{H}-451$ & parallel & 2371 \\
\hline $\mathrm{H}-451$ & perpendicular & $2648 \pm 270$ \\
\hline
\end{tabular}

6.2.5. Cesium Sorption

Cesium sorptivity and cesium vapor pressure measurements have been made on $\mathrm{H}-451$ and $\mathrm{H}-327$ graphites. No differences were found in either cesium sorption or cesium vapor pressure properties between unirradiated $\mathrm{H}-327$ and $\mathrm{H}-451$ graphites.

Preliminary results from capsule $O G-1$ at $700^{\circ}$ to $1150^{\circ} \mathrm{C}$ and 2.9 to $3.7 \times 10^{21} \mathrm{n} / \mathrm{cm}^{2}$ on irradiated $\mathrm{H}-327$ and $\mathrm{H}-451$ graphites showed that irradiation caused an average increase of a factor of 7 in their cesium sorptivity. 

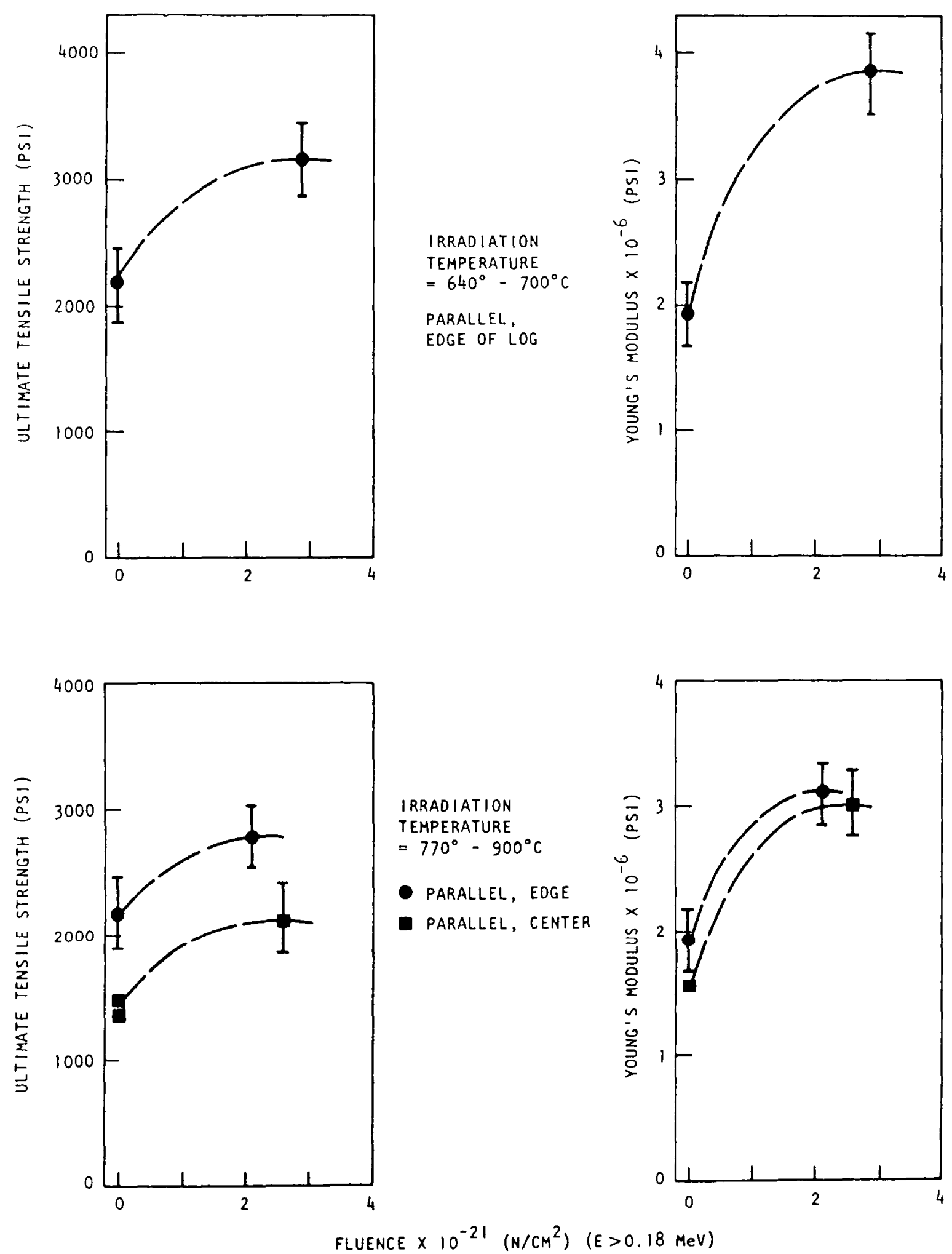

Fig. 6-11. Change in ultimate tensile strength and Young's modulus as a function of fluence, $\mathrm{H}-327$ graphite, $640^{\circ}$ to $700^{\circ} \mathrm{C}$ and $770^{\circ}$ to $900^{\circ} \mathrm{C}$ 


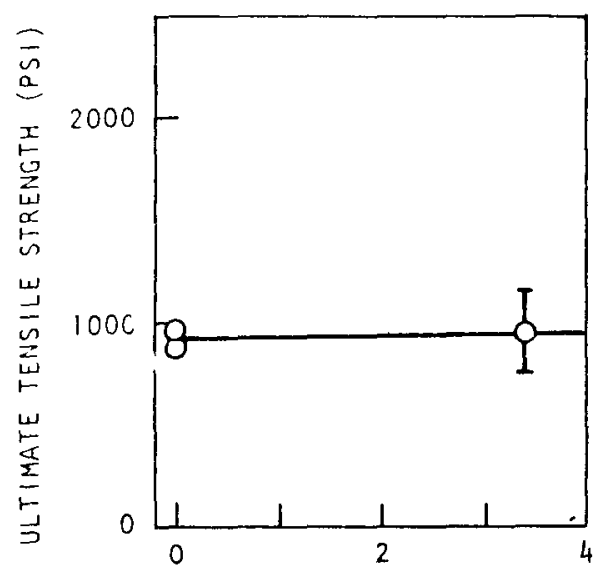

IRRADIATION

TEMPERATURE

$=960^{\circ}-1020^{\circ} \mathrm{C}$
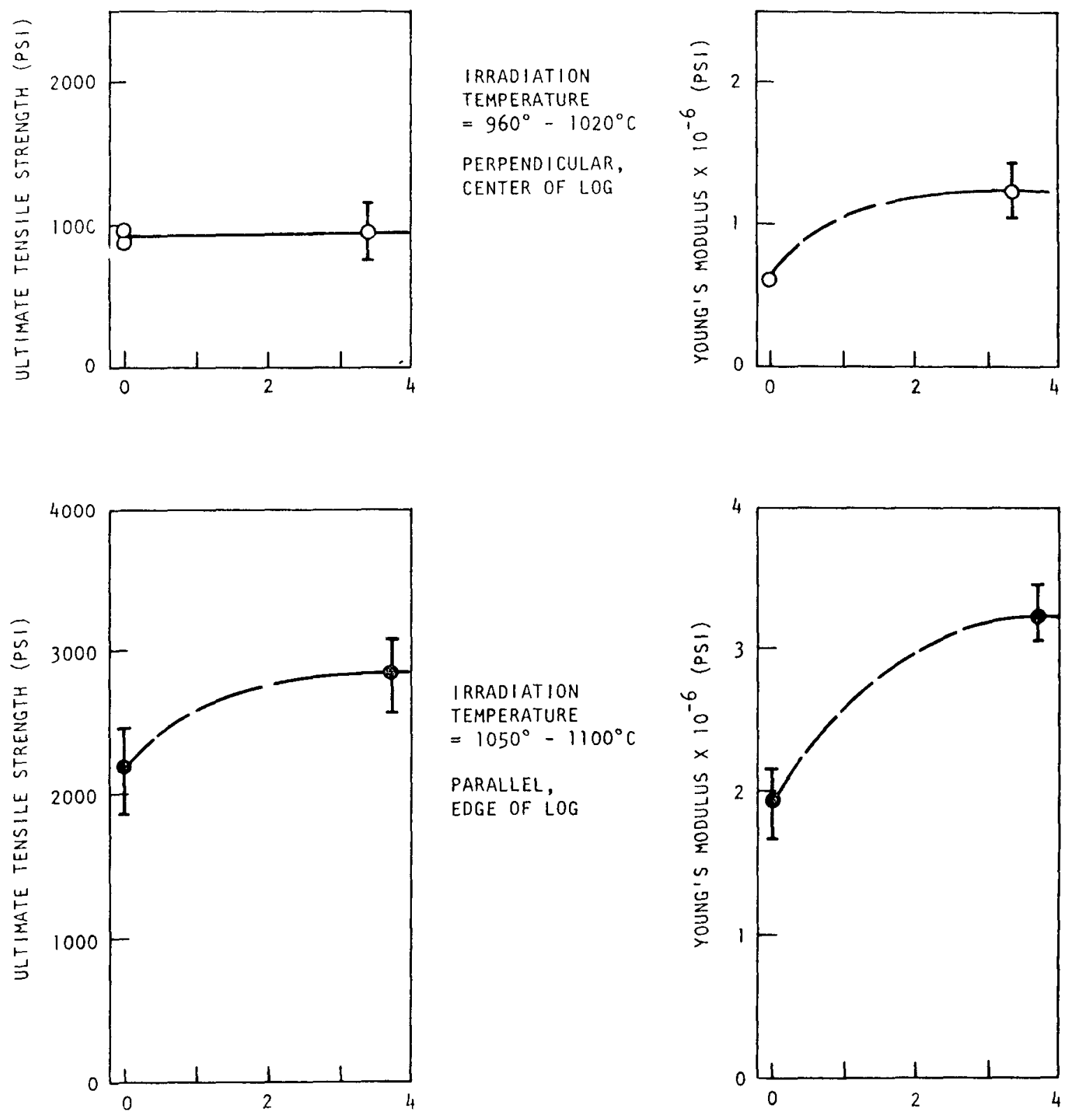

FLUENCE $\times 10^{-21}\left(\mathrm{~N} / \mathrm{CM}^{2}\right) \quad(\mathrm{E}>0.18 \mathrm{MeV})$

F1g. 6-12. Change in ultimate tensile strength and Young's modulus as a function of fluence, $\mathrm{H}-327$ graphite, $960^{\circ}$ to $1020^{\circ} \mathrm{C}$ and $1050^{\circ}$ to $1100^{\circ} \mathrm{C}$ 


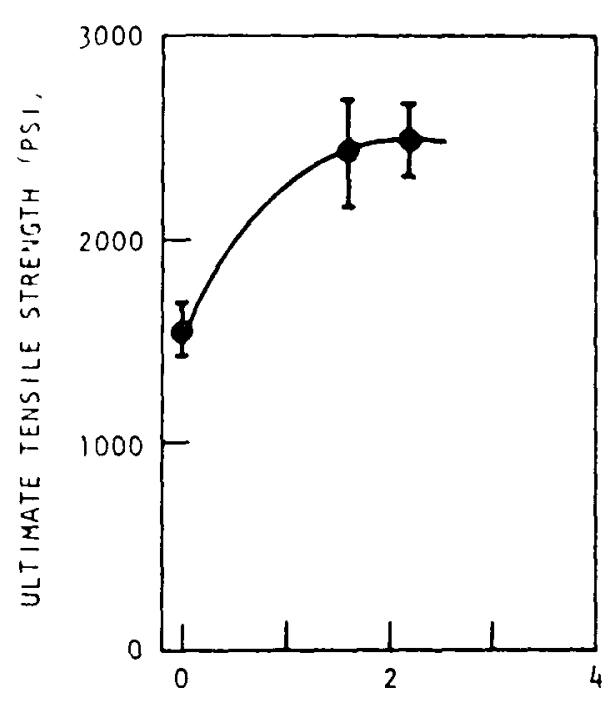

IRRAOIATION
TEMPERATURE
$=580^{\circ}-630^{\circ} \mathrm{C}$
CENTER OF LOG
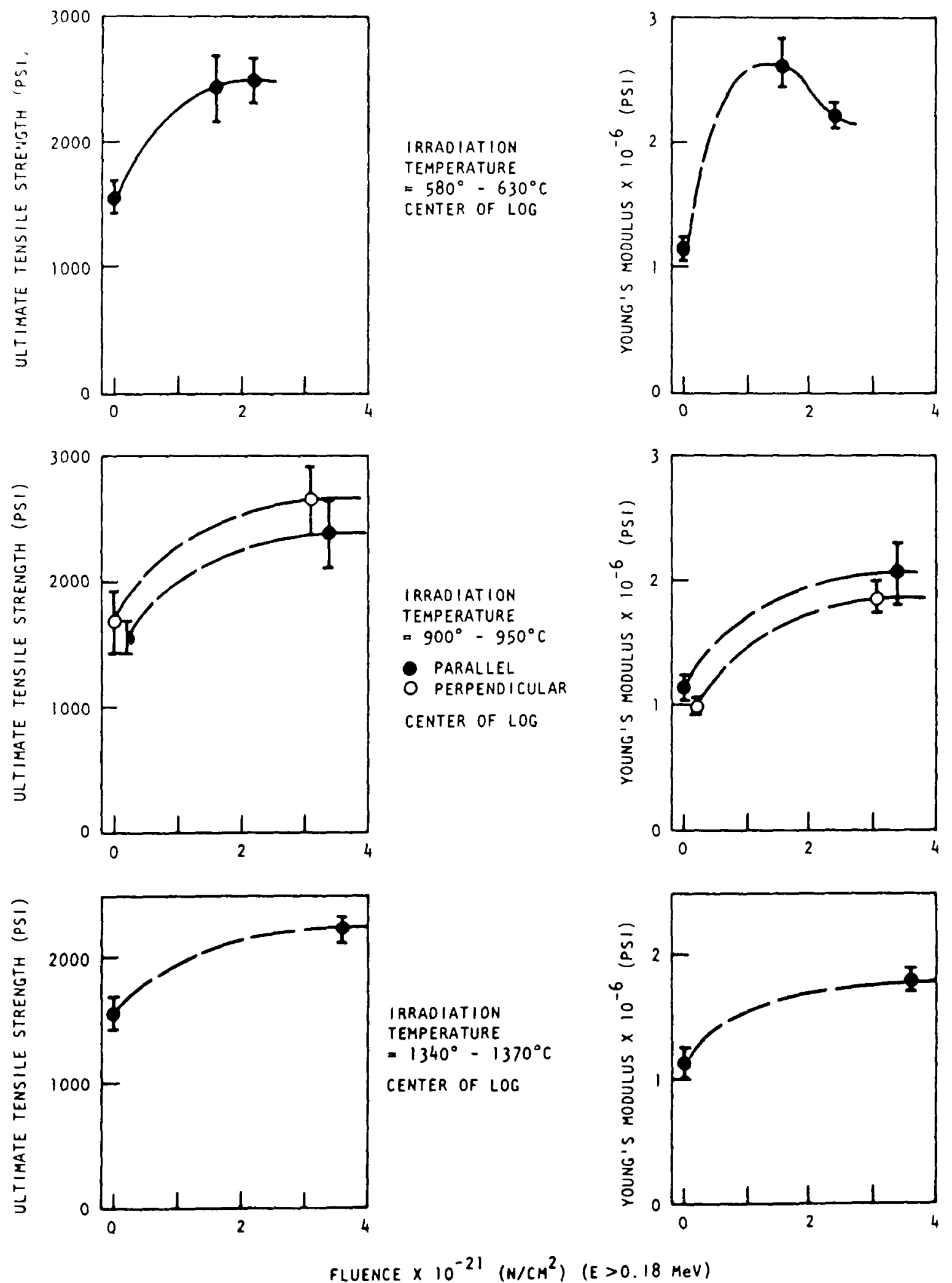

Fig. 6-13. Change in ultimate tensile strength and Young's modulus as a function of fluence, $\mathrm{H}-451$ graphite, $580^{\circ}$ to $630^{\circ} \mathrm{C}, 900^{\circ}$ to $950^{\circ} \mathrm{C}$, and $1340^{\circ}$ to $1370^{\circ} \mathrm{C}$ 


\section{ACKNOWLEDGMENTS}

The authors wish to express their thanks to L. Bailey, C. H. Richards, Jr., J. R. Whaley, and H. H. Evans who performed the laboratory work. Grateful acknowledgments are given to J. S. Steibel and the GAC Capsule Irradiation Branch who designed and fabricated capsule OG-1. Thanks are also extended to D. W. Stevens for his help with thermal property measurements. Thanks are extended to R. D. Burnette and D. D. Jensen for the oxidation data and to L. Yang and to H. G. Staley for the Ce sorption data. 


\section{REFERENCES}

1. Homeyer, W. G., and R. M. Sullivan, General Atomic Company unpublished data, 1974 .

2. Hutcheon, J. M., and R. P. Thorne, in Proceedings of Second Conference on Industrial Carbons and Graphites, Society of Chemical Industry, London, 1966, p. 441.

3. Nettley, P. T., et al., in Proceedings of Symposium on Advanced and High-Temperature Gas-Cooled Reactors, IAEA, Vienna, 1969, p. 603.

4. Prince, N., et al., in Proceedings of Conference on Graphite Structures for Nuclear Reactors, Institute of Mechanical Engineers, London, 1972, p. 87 .

5. Welch, E. E., et al., in Proceedings of Conference on Graphite Structures for Nuclear Reactors, Institute of Mechanical Engineers, London, 1972 , p. 367.

6. Blackstone, R., et al., in Proceedings of Symposium on Radiation Damage to Reactor Materials, Vol. II, IAEA, Vienna, 1969, p. 543.

7. Everett, M. R., in Proceedings of Third Conference on Industrial Carbons and Graphites, Society of Chemical Industry, London, 1971, p. 373 .

8. Everett, M. R., et al., in Proceedings of Conference on Graphite Structures for Nuclear Reactors, Institute of Mechanical Engineers, London, 1972, p. 321.

9. Blackstone, R., et al., paper presented at the 11 th Conference on Carbon, Gatlinburg, Tennessee, June 1973.

10. Everett, M. R., et al., Carbon 9, 417 (1971).

11. Everett, M. R., and F. Ridealgh, High Temperatures - High Pressures 4, 329 (1972).

12. Engle, G. B., and A. L. Pitner, "High-Temperature Irradiation Behavior of Production-Grade Nuclear Graphites, USAEC Report GA-9973, Gulf General Atomic, July 10, 1972 . 
13. Engle, G. B., and K. Koyama, "Thermal Conductivity Changes in Nuclear Graphites at High Temperatures and High Fluences," USAEC Report Gulf-GA-A12137, Gulf General Atomic, June 30, 1972.

14. Engle, G. B., "Irradiation Behavior of Nuclear Graphites at Elevated Temperatures," Carbon 9, 539 (1971).

15. Motett, P., et al., "Physical and Mechanical Properties of Nuclear Graphites, Their Application in High Temperature Reactors," "Carbon 72," International Carbon Conference, Baden-Baden, West Germany, June 1972 .

16. White, J. L., and R. J. Price, "The Formation of Mesophase Microstructure During the Pyrolysis of Selected Coker Feedstocks," Gulf General Atomic Report Gulf-GA-A12722, August 20, 1973.

17. Cobb, H. R. W., G. B. Engle, and S. J. S. Parry, "Characterization of Production-Grade H-327 Graphite for HTGR Design," in Proceedings of Conference on Continuum Aspects of Graphite Design, Gatlinburg, Tennessee, November 9-12, 1970, USAEC Report CONF-701105, p. 98.

18. Walker, P. L., et al., Adv. in Catalysis 11, 133, (1959).

19. "HTGR Base Program Quarterly Progress Report for the Period Ending November 30, 1971," USAEC Report Gulf-GA-A10930, Gulf General Atomic, December 31, 1971.

20. Peroomian, M. B., A. W. Barsel1, and J. C. Saeger, "Oxide-3: A Computer Code for Analysis of HTGR Steam or Air Ingress Accidents," General Atomic Company Report GA-A12493, (GA-LTR-7) January 15, 1972.

21. Giberson, R. C., and G. L. Tingey, "Reaction of Gaseous Impurities in a High-Temperature Gas-Cooled Reactor," USAEC Report BNWL-974, Battelle Northwest Laboratories, December 1968.

22. "Public Service Company of Colorado 330-MW(e) High-Temperature GasCooled Reactor Research and Development Program, Quarterly Progress Report for the Period Ending March 31, 1970," USAEC Report GA-10010, Gulf General Atomic, April 30, 1970.

23. Engle, G. B., "Relationship Between Crystal Structure and Properties and Irradiation Behavior of Reactor Graphites," Gulf General Atomic Report Gulf-GA-A12124, June 30, 1972. 
24. Price, R. J., "Review of Thermal Conductivity of Nuclear Graphite under HTGR Conditions," Gulf General Atomic Report Gulf-GA-A12615 (GA-LTR-3), September 1973.

25. Price, R. J., "Calculation of the Thermal Conductivity of Irradiated Graphite for a Changing Irradiation Temperature," October 16, 1973, General Atomic Company unpublished data. 
APPENDIX

$A-1$ 
TABLE A-1

BULK DENSITIES OF H-451 GRAPHITE

\begin{tabular}{|c|c|c|c|c|c|}
\hline $\begin{array}{l}\text { Specimen } \\
\text { No. }\end{array}$ & $\begin{array}{l}\text { Location } \\
\text { in } \log \end{array}$ & $\begin{array}{l}\text { Bulk Density } \\
\left(\mathrm{g} / \mathrm{cm}^{3}\right)\end{array}$ & $\begin{array}{l}\text { Specimen } \\
\text { No. }\end{array}$ & $\begin{array}{l}\text { Location } \\
\text { in Log }\end{array}$ & $\begin{array}{l}\text { Bulk Density } \\
\left(\mathrm{g} / \mathrm{cm}^{3}\right)\end{array}$ \\
\hline \multicolumn{6}{|c|}{ Log Number $5651-28$} \\
\hline $\begin{array}{r}5651-28-201 \\
202 \\
203 \\
204 \\
205 \\
206 \\
207 \\
208 \\
209 \\
210 \\
211 \\
212 \\
221 \\
222 \\
223 \\
226 \\
227 \\
228 \\
231 \\
232 \\
233 \\
236 \\
237 \\
238 \\
241 \\
242 \\
243 \\
246 \\
247 \\
248 \\
251 \\
252 \\
253 \\
256\end{array}$ & $\begin{array}{l}\text { Midlength } \\
\text { center }\end{array}$ & $\begin{array}{l}1.70 \\
1.74 \\
1.74 \\
1.75 \\
1.75 \\
1.74 \\
1.74 \\
1.73 \\
1.73 \\
1.75 \\
1.74 \\
1.74 \\
1.75 \\
1.75 \\
1.74 \\
1.69 \\
1.75 \\
1.73 \\
1.75 \\
1.75 \\
1.74 \\
1.65 \\
1.75 \\
1.74 \\
1.77 \\
1.74 \\
1.72 \\
1.75 \\
1.75 \\
1.75 \\
1.72 \\
1.74 \\
1.75 \\
1.73 \\
1.19 \\
1.74\end{array}$ & $\begin{array}{r}5651-28-224 \\
225 \\
229 \\
230 \\
234 \\
235 \\
239 \\
240 \\
244 \\
245 \\
249 \\
250 \\
254 \\
255\end{array}$ & $\begin{array}{l}\text { Midlength } \\
\text { edge }\end{array}$ & $\begin{array}{l}1.72 \\
1.75 \\
1.74 \\
1.75 \\
1.74 \\
1.74 \\
1.74 \\
1.76 \\
1.75 \\
1.75 \\
1.73 \\
1.75 \\
1.74 \\
1.72 \\
1.74 \pm 0.01\end{array}$ \\
\hline
\end{tabular}


TABLE A-1 (continued)

\begin{tabular}{|c|c|c|c|c|c|}
\hline $\begin{array}{c}\text { Specimen } \\
\text { No. }\end{array}$ & $\begin{array}{l}\text { Location } \\
\text { in Log }\end{array}$ & $\begin{array}{c}\text { Bulk Density } \\
\left(\mathrm{g} / \mathrm{cm}^{3}\right)\end{array}$ & $\begin{array}{c}\text { Specimen } \\
\text { No. }\end{array}$ & $\begin{array}{l}\text { Location } \\
\text { in Log }\end{array}$ & $\begin{array}{c}\text { Bulk Density } \\
\left(\mathrm{g} / \mathrm{cm}^{3}\right)\end{array}$ \\
\hline \multicolumn{6}{|c|}{ Log Number 5651-58 } \\
\hline $\begin{array}{r}5651-58-1 \\
2 \\
3 \\
4 \\
5 \\
6 \\
7 \\
8 \\
9 \\
10 \\
11 \\
12 \\
13 \\
14 \\
15 \\
16 \\
17 \\
18 \\
19\end{array}$ & $\begin{array}{l}\text { Midlength } \\
\text { center }\end{array}$ & $\begin{array}{l}1.73 \\
1.73 \\
1.73 \\
1.72 \\
1.72 \\
1.72 \\
1.73 \\
1.73 \\
1.74 \\
1.73 \\
1.73 \\
1.74 \\
1.73 \\
1.73 \\
1.73 \\
1.73 \\
1.73 \\
1.73 \\
1.73 \\
1.73 \pm 0.01\end{array}$ & $\begin{array}{r}5651-58-21 \\
22 \\
23 \\
24 \\
25 \\
26 \\
27 \\
28 \\
29\end{array}$ & $\begin{array}{l}\text { Midlength } \\
\text { edge }\end{array}$ & $\begin{array}{l}1.73 \\
1.73 \\
1.73 \\
1.73 \\
1.73 \\
1.73 \\
1.73 \\
1.73 \\
1.73 \\
1.73 \pm 0.00\end{array}$ \\
\hline
\end{tabular}


TABLE A-2

BULK DENSITIES OF TS-1240 GRAPHITE

\begin{tabular}{|c|c|c|c|c|c|}
\hline $\begin{array}{l}\text { Specimen } \\
\text { No. }\end{array}$ & $\begin{array}{l}\text { Location } \\
\text { in Log }\end{array}$ & \begin{tabular}{|c|} 
Bulk Density \\
$\left(\mathrm{g} / \mathrm{cm}^{3}\right)$
\end{tabular} & $\begin{array}{l}\text { Specimen } \\
\text { No. }\end{array}$ & $\begin{array}{l}\text { Location } \\
\text { in Log }\end{array}$ & $\begin{array}{c}\text { Bulk Density } \\
\left(\mathrm{g} / \mathrm{cm}^{3}\right)\end{array}$ \\
\hline \multicolumn{3}{|r|}{ Log Number } & \multicolumn{3}{|l|}{$5651-72$} \\
\hline $\begin{array}{r}5651-72-3 \mathrm{~A}-151 \\
153 \\
155 \\
157\end{array}$ & \multirow[t]{5}{*}{$\begin{array}{l}\text { Midlength } \\
\text { edge }\end{array}$} & $\begin{array}{l}1.73 \\
1.76 \\
1.77 \\
1.77\end{array}$ & $\begin{array}{r}5651-72-3 A-50 \\
53 \\
54 \\
58\end{array}$ & \multirow[t]{5}{*}{$\begin{array}{l}\text { Midlength } \\
\text { center }\end{array}$} & $\begin{array}{l}1.72 \\
1.72 \\
1.72 \\
1.74\end{array}$ \\
\hline $\begin{array}{r}-3 \mathrm{~B}-161 \\
162 \\
164 \\
166\end{array}$ & & $\begin{array}{l}1.77 \\
1.73 \\
1.75 \\
1.74\end{array}$ & $\begin{array}{r}-3 B-61 \\
64 \\
65 \\
69\end{array}$ & & $\begin{array}{l}1.74 \\
1.73 \\
1.72 \\
1.73\end{array}$ \\
\hline $\begin{array}{r}-3 \mathrm{~A}-175 \\
176 \\
179 \\
180\end{array}$ & & $\begin{array}{l}1.76 \\
1.76 \\
1.75 \\
1.75\end{array}$ & $\begin{array}{r}-3 A-76 \\
77 \\
80\end{array}$ & & $\begin{array}{l}1.74 \\
1.73 \\
1.73\end{array}$ \\
\hline $\begin{array}{r}-3 \mathrm{~B}-193 \\
194 \\
197 \\
198\end{array}$ & & $\begin{array}{l}1.73 \\
1.73 \\
1.75 \\
1.75 \\
\end{array}$ & $\begin{array}{r}-3 \mathrm{~B}-87 \\
88 \\
89 \\
92\end{array}$ & & $\begin{array}{l}1.72 \\
1.73 \\
1.73 \\
1.73 \\
\end{array}$ \\
\hline & & $1.75 \pm 0.02$ & & & $1.73 \pm 0.01$ \\
\hline $\begin{array}{r}5651-72-1 \mathrm{~A}-101 \\
103 \\
105 \\
107\end{array}$ & \multirow[t]{4}{*}{ End edge } & $\begin{array}{l}1.74 \\
1.75 \\
1.74 \\
1.77\end{array}$ & 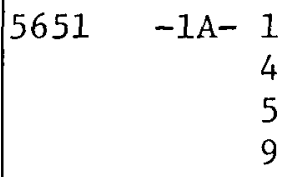 & \multirow[t]{4}{*}{ End center } & $\begin{array}{l}1.74 \\
1.72 \\
1.70 \\
1.73\end{array}$ \\
\hline $\begin{array}{r}-1 B-111 \\
112 \\
114 \\
116\end{array}$ & & $\begin{array}{l}1.75 \\
1.75 \\
1.73 \\
1.71\end{array}$ & $\begin{array}{r}-1 B-11 \\
14 \\
15 \\
19\end{array}$ & & $\begin{array}{l}1.73 \\
1.72 \\
1.71 \\
1.73\end{array}$ \\
\hline $\begin{array}{r}-1 A-125 \\
126 \\
129 \\
130\end{array}$ & & $\begin{array}{l}1.74 \\
1.75 \\
1.75 \\
1.75\end{array}$ & $\begin{array}{r}-1 A-25 \\
26 \\
27 \\
28\end{array}$ & & $\begin{array}{l}1.75 \\
1.74 \\
1.72 \\
1.72\end{array}$ \\
\hline $\begin{array}{r}-1 B-142 \\
143 \\
146 \\
147\end{array}$ & & $\begin{array}{l}1.74 \\
1.74 \\
1.74 \\
1.73 \\
1.74 \pm 0.01\end{array}$ & $\begin{array}{r}-1 B-37 \\
38 \\
39 \\
42\end{array}$ & & $\begin{array}{l}1.73 \\
1.72 \\
1.73 \\
1.72 \\
1.73 \pm 0.01\end{array}$ \\
\hline
\end{tabular}


TABLE A-2 (continued)

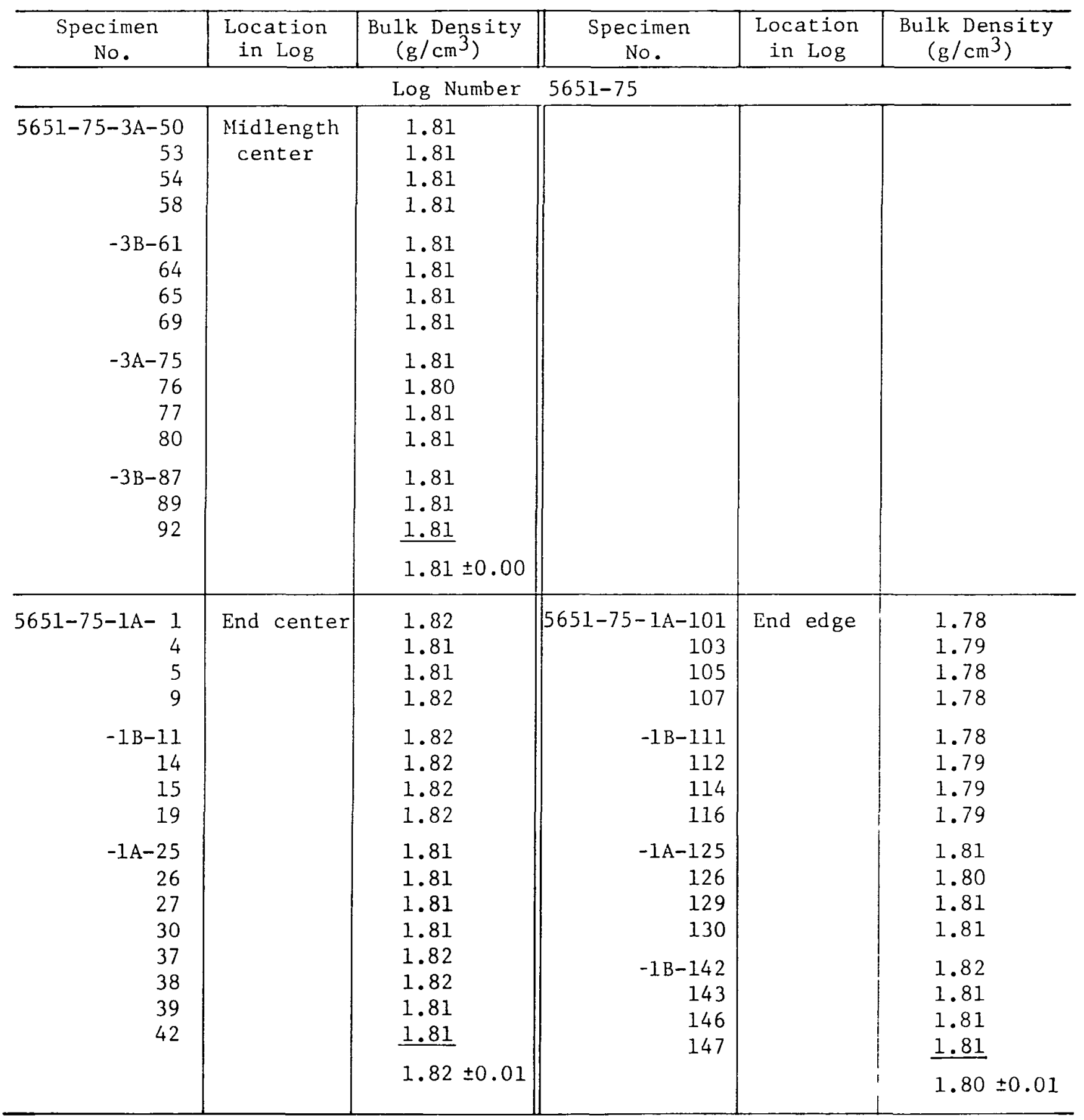


TABLE $A-3$

THERMAL EXPANSIVITY OF H-451 GRAPHITE

(Log Number 5651-28)

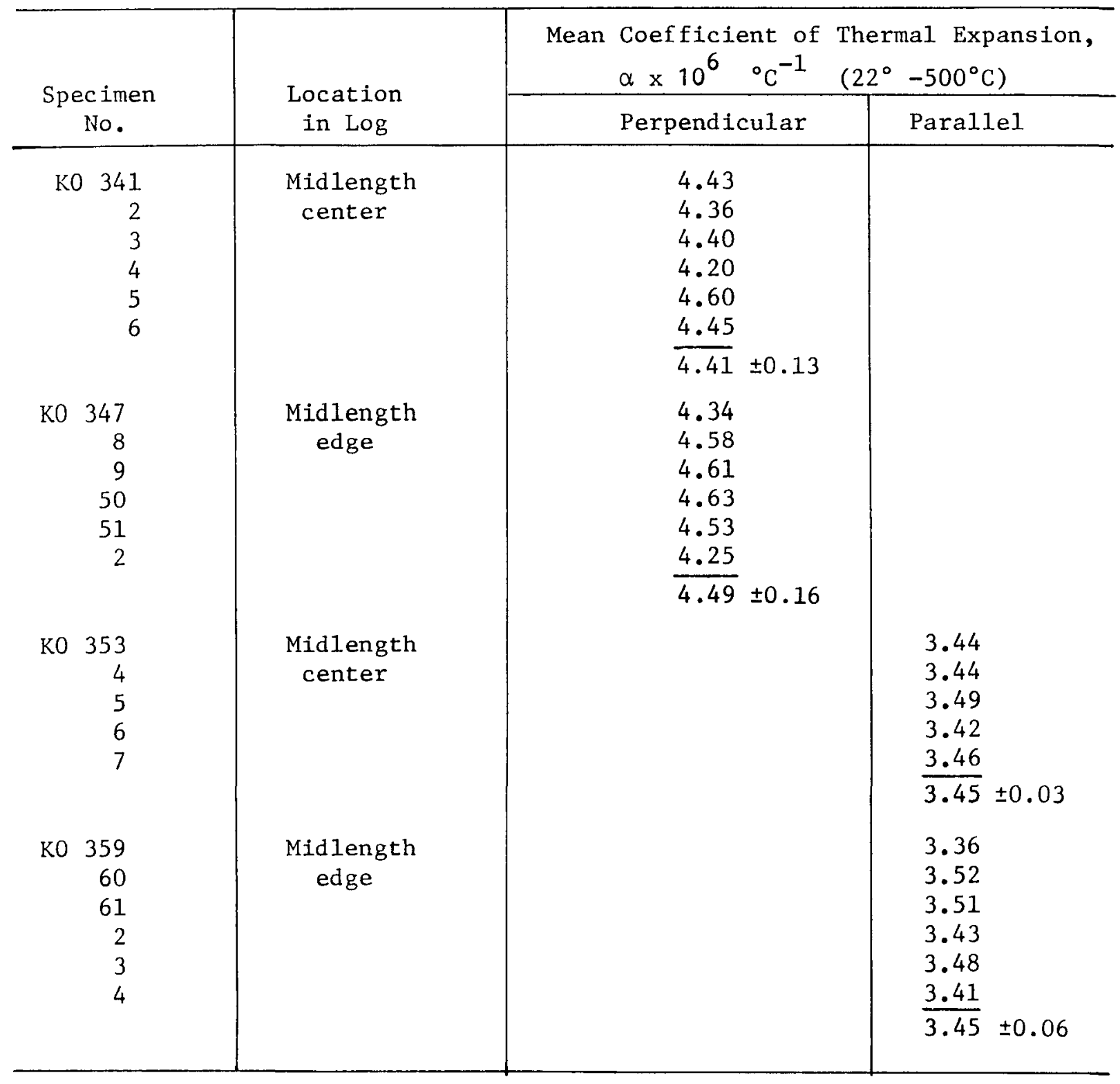


TABLE A-4

THERMAL EXPANSIVITY OF H-429 GRAPHITE

(Log Number 5651-38)

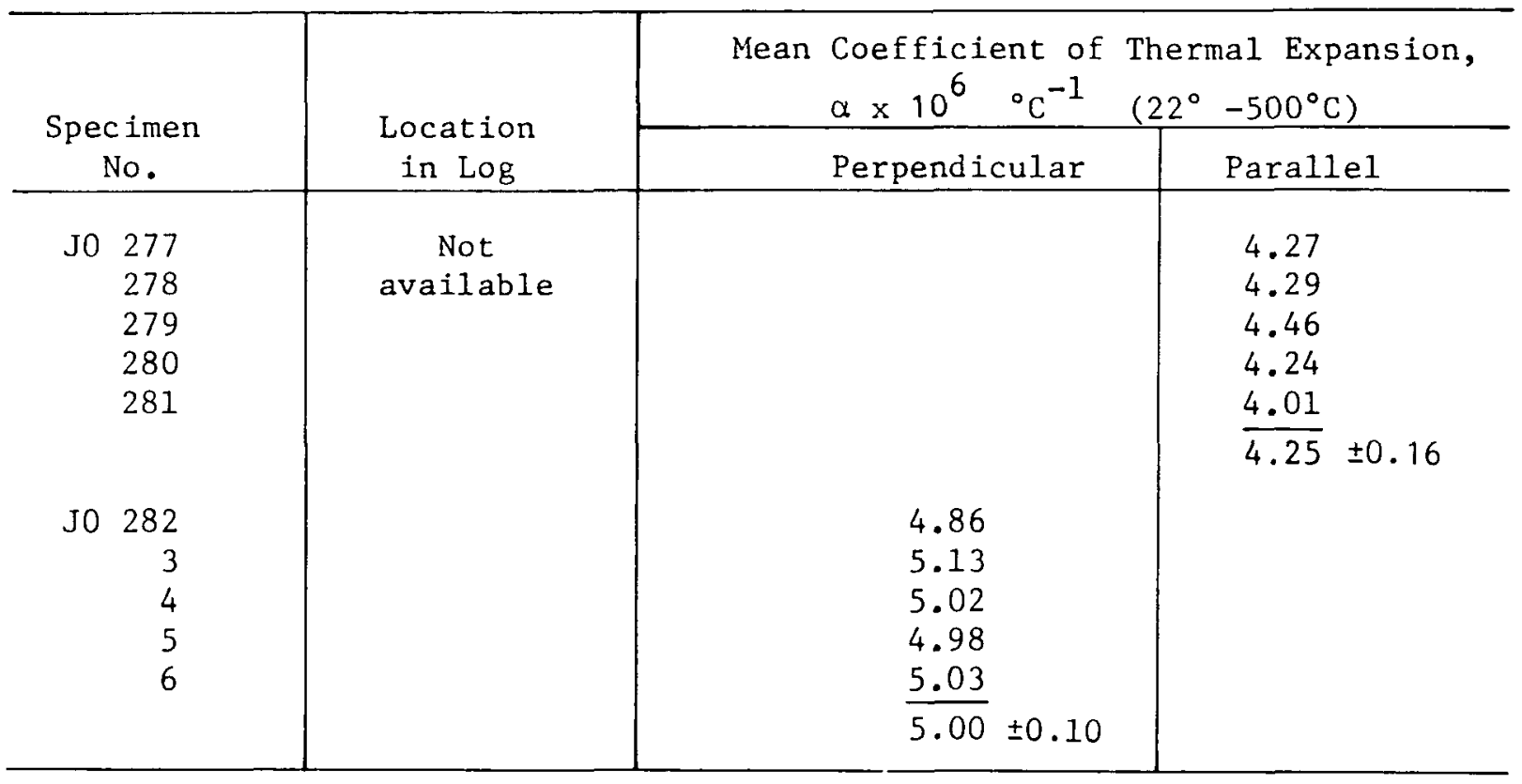

TABLE A-5

THERMAL EXPANSIVITY OF $\mathrm{P}_{3}$ JHAN GRAPHITE

(Log Number 5651-53)

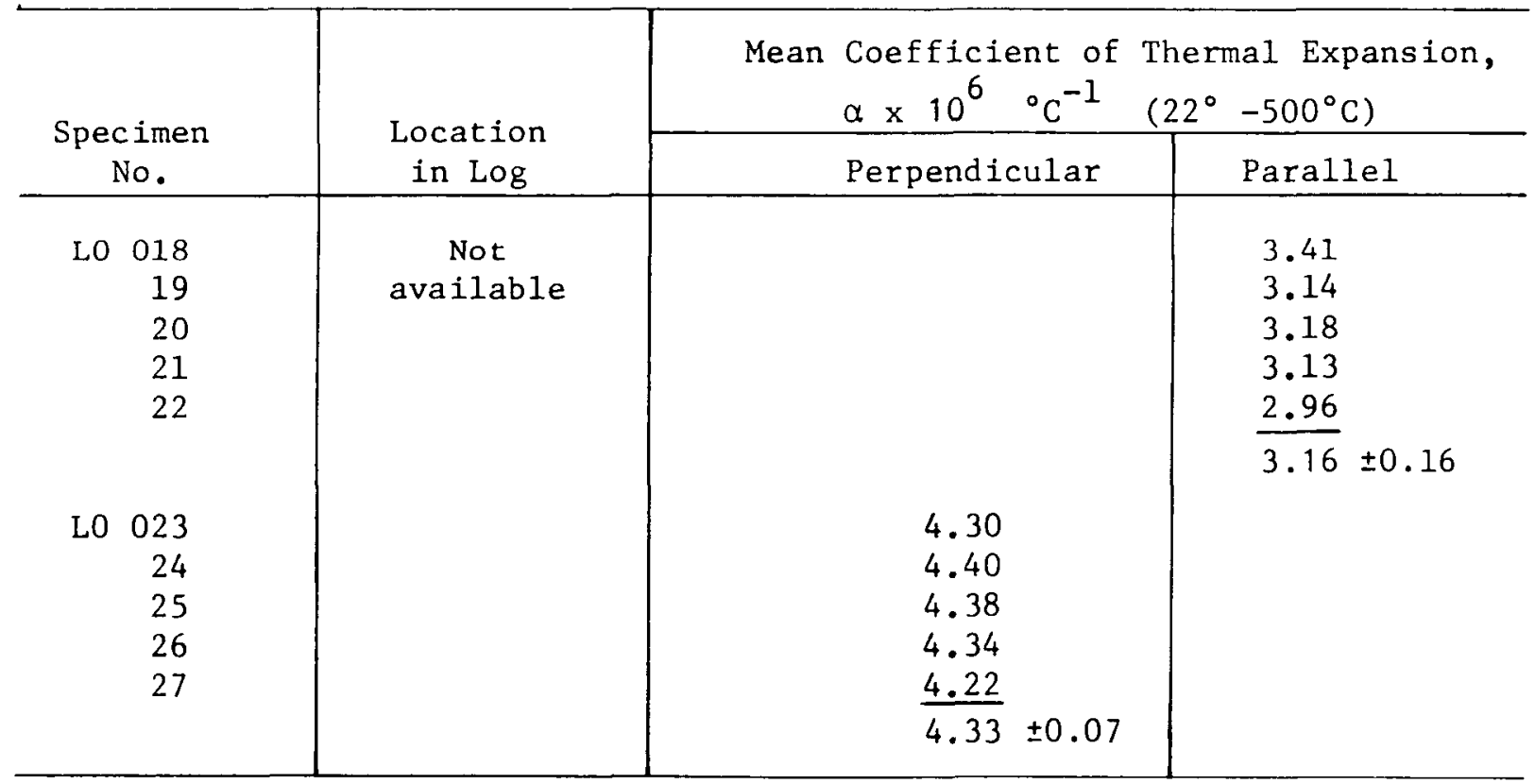


TABLE A-6

THERMAL EXPANSIVITY OF H-327 GRAPHITE

\begin{tabular}{|c|c|c|c|c|}
\hline \multirow{2}{*}{\multicolumn{2}{|c|}{$\begin{array}{l}\text { Specimen } \\
\text { No. }\end{array}$}} & \multirow{2}{*}{$\begin{array}{l}\text { Location } \\
\text { in Log }\end{array}$} & \multicolumn{2}{|c|}{$\begin{array}{l}\text { Mean Coefficient of Thermal Expansion, } \\
\alpha \times 10^{6}{ }^{\circ} \mathrm{C}^{-1}\left(22^{\circ}-500^{\circ} \mathrm{C}\right)\end{array}$} \\
\hline & & & Perpendicular & Para11e1 \\
\hline & $\begin{array}{l}238 \\
239 \\
254 \\
255\end{array}$ & $\begin{array}{c}\text { Not } \\
\text { available }\end{array}$ & $\begin{array}{l}2.51 \\
3.75 \\
3.62 \\
3.65\end{array}$ & \\
\hline IO & $\begin{array}{l}296 \\
298 \\
300 \\
302 \\
304 \\
306 \\
308 \\
310 \\
312 \\
314\end{array}$ & & $\begin{array}{l}3.77 \\
3.67 \\
3.54 \\
3.53 \\
3.83 \\
3.81 \\
3.75 \\
3.87 \\
3.81 \\
3.63\end{array}$ & \\
\hline JO & $\begin{array}{l}422 \\
424 \\
426 \\
428\end{array}$ & & $\begin{array}{l}4.06 \\
3.95 \\
3.82 \\
\frac{4.02}{3.70 \pm 0.33}\end{array}$ & \\
\hline HO & $\begin{array}{l}240 \\
241 \\
256 \\
257\end{array}$ & & & $\begin{array}{l}1.80 \\
1.63 \\
1.59 \\
1.98\end{array}$ \\
\hline I0 & $\begin{array}{l}297 \\
299 \\
301 \\
303 \\
305 \\
307 \\
309 \\
311 \\
313 \\
315\end{array}$ & & & $\begin{array}{l}1.91 \\
2.03 \\
1.98 \\
1.87 \\
2.09 \\
2.06 \\
2.06 \\
2.07 \\
1.98 \\
1.87\end{array}$ \\
\hline JO & $\begin{array}{l}421 \\
423 \\
425 \\
427\end{array}$ & & & $\begin{array}{l}2.12 \\
2.01 \\
\frac{2.09}{1.96 \pm 0.16}\end{array}$ \\
\hline
\end{tabular}


TABLE A-7

THERMAL CONDUCTIVITY OF H-451 GRAPHITE

(Log Number 5651-28)

\begin{tabular}{|c|c|c|c|c|c|c|c|}
\hline \multirow{2}{*}{$\begin{array}{c}\text { Specimen } \\
\text { No. }\end{array}$} & \multirow[b]{2}{*}{ Orientation } & \multirow{2}{*}{$\begin{array}{c}\text { Location } \\
\text { in Log }\end{array}$} & \multicolumn{5}{|c|}{ Thermal Conductivity $\left(\mathrm{cal} / \mathrm{cm}-\mathrm{sec}-{ }^{\circ} \mathrm{C}\right)$} \\
\hline & & & $22^{\circ} \mathrm{C}$ & $200^{\circ} \mathrm{C}$ & $400^{\circ} \mathrm{C}$ & $500^{\circ} \mathrm{C}$ & $800^{\circ} \mathrm{C}$ \\
\hline $\mathrm{L}-0011$ & Perpendicular & Midlength & 0.302 & 0.249 & 0.210 & 0.188 & 0.147 \\
\hline 0012 & & center & 0.324 & 0.273 & 0.235 & 0.216 & 0.163 \\
\hline 0013 & & & 0.315 & 0.277 & 0.225 & 0.210 & 0.160 \\
\hline 0014 & & & 0.317 & 0.275 & 0.223 & 0.202 & 0.145 \\
\hline 0015 & & & 0.310 & 0.270 & 0.235 & 0.214 & 0.175 \\
\hline 0017 & & & 0.287 & 0.245 & 0.204 & 0.190 & 0.150 \\
\hline 0028 & & & 0.283 & 0.265 & 0.225 & 0.212 & 0.155 \\
\hline 0029 & & & 0.278 & 0.265 & 0.226 & 0.215 & 0.165 \\
\hline 0030 & & & 0.274 & 0.245 & 0.212 & 0.200 & 0.155 \\
\hline 0031 & & & 0.270 & 0.261 & 0.223 & 0.203 & 0.162 \\
\hline 0033 & & & 0.295 & 0.264 & 0.224 & 0.207 & 0.162 \\
\hline \multirow[t]{2}{*}{0034} & & & 0.285 & 0.260 & 0.222 & 0.191 & 0.154 \\
\hline & & & $\begin{array}{r}0.295 \\
\pm 0.018\end{array}$ & $\begin{array}{r}0.262 \\
\pm 0.011\end{array}$ & $\begin{array}{r}0.222 \\
\pm 0.009\end{array}$ & $\begin{array}{r}0.204 \\
\pm 0.010\end{array}$ & $\begin{array}{r}0.158 \\
\pm 0.008\end{array}$ \\
\hline $\bar{L}-\overline{0137}$ & Parallel & Midlength & 0.355 & 0.308 & 0.220 & 0.214 & 0.166 \\
\hline 0138 & & center & 0.346 & 0.309 & 0.252 & 0.234 & 0.179 \\
\hline 0139 & & & 0.344 & 0.306 & 0.250 & 0.237 & 0.188 \\
\hline 0140 & & & 0.345 & 0.307 & 0.257 & 0.230 & 0.174 \\
\hline 0141 & & & 0.347 & 0.300 & 0.253 & 0.231 & 0.175 \\
\hline 0142 & & & 0.346 & 0.305 & 0.264 & 0.234 & 0.173 \\
\hline 0143 & & & 0.351 & 0.303 & 0.244 & 0.224 & 0.168 \\
\hline 0144 & & & 0.343 & 0.297 & 0.257 & 0.225 & 0.173 \\
\hline 0145 & & & 0.345 & 0.298 & 0.251 & 0.221 & 0.174 \\
\hline 0146 & & & 0.345 & 0.291 & 0.232 & 0.213 & 0.172 \\
\hline \multirow{4}{*}{$\begin{array}{l}0147 \\
0148\end{array}$} & & & 0.346 & 0.300 & 0.241 & 0.222 & 0.173 \\
\hline & & & 0.348 & 0.301 & 0.232 & 0.226 & 0.171 \\
\hline & & & 0.347 & 0.302 & 0.246 & 0.226 & 0.174 \\
\hline & & & \pm 0.003 & \pm 0.005 & \pm 0.013 & \pm 0.008 & \pm 0.006 \\
\hline
\end{tabular}


TABLE A-8

THERMAL CONDUCTIVITY OF TS -1240 GRAPHITE

(Log Number 5651-72)

\begin{tabular}{|c|c|c|c|c|c|c|c|}
\hline \multirow[b]{2}{*}{$\begin{array}{l}\text { Specimen } \\
\text { No. }\end{array}$} & \multirow[b]{2}{*}{ Orientation } & \multirow[b]{2}{*}{$\begin{array}{l}\text { Location } \\
\text { in Log }\end{array}$} & \multicolumn{5}{|c|}{ Thermal Conductivity $\left(\mathrm{cal} / \mathrm{cm}-\mathrm{sec}-{ }^{\circ} \mathrm{C}\right)$} \\
\hline & & & $22^{\circ} \mathrm{C}$ & $200^{\circ} \mathrm{C}$ & $400^{\circ} \mathrm{C}$ & $500^{\circ} \mathrm{C}$ & $800^{\circ} \mathrm{C}$ \\
\hline $\begin{array}{c}5651-72-3 A- \\
78 A \\
78 B \\
81 A \\
81 B \\
5651-72-3 B- \\
90 A \\
90 B \\
93 A \\
93 B\end{array}$ & Perpendicular & $\begin{array}{l}\text { Midlength } \\
\text { center }\end{array}$ & $\begin{array}{r}0.219 \\
0.243 \\
0.229 \\
0.247 \\
0.242 \\
0.248 \\
0.231 \\
0.222 \\
0.235 \\
\pm 0.011\end{array}$ & $\begin{array}{r}0.208 \\
0.230 \\
0.216 \\
0.219 \\
0.198 \\
0.216 \\
0.215 \\
0.201 \\
0.213 \\
\pm 0.010\end{array}$ & $\begin{array}{r}0.183 \\
0.193 \\
0.181 \\
0.186 \\
0.178 \\
0.184 \\
0.187 \\
0.170 \\
0.183 \\
\pm 0.007\end{array}$ & $\begin{array}{r}0.163 \\
0.185 \\
0.175 \\
0.167 \\
0.166 \\
0.177 \\
0.183 \\
0.155 \\
0.171 \\
\pm 0.010\end{array}$ & $\begin{array}{r}0.123 \\
0.146 \\
0.141 \\
0.130 \\
0.127 \\
0.139 \\
0.142 \\
0.125 \\
0.134 \\
\pm 0.009\end{array}$ \\
\hline $\begin{array}{c}5651-72-3 \mathrm{~A}- \\
51 \mathrm{~A} \\
51 \mathrm{~B} \\
55 \mathrm{~A} \\
55 \mathrm{~B} \\
5651-72-3 \mathrm{~B}- \\
62 \mathrm{~A} \\
62 \mathrm{~B} \\
66 \mathrm{~A}\end{array}$ & Parallel & $\begin{array}{l}\text { Midlength } \\
\text { center }\end{array}$ & $\begin{array}{r}0.234 \\
0.242 \\
0.265 \\
0.256 \\
0.224 \\
0.231 \\
0.266 \\
0.245 \\
\pm 0.017\end{array}$ & $\begin{array}{r}0.222 \\
0.236 \\
0.237 \\
0.220 \\
0.207 \\
0.205 \\
0.232 \\
0.222 \\
\pm 0.013 \\
\end{array}$ & $\begin{array}{r}0.196 \\
0.190 \\
0.193 \\
0.193 \\
0.183 \\
0.182 \\
0.213 \\
0.193 \\
\pm 0.010 \\
\end{array}$ & $\begin{array}{r}0.169 \\
0.177 \\
0.179 \\
0.162 \\
0.162 \\
0.166 \\
0.193 \\
0.173 \\
\pm 0.011 \\
\end{array}$ & $\begin{array}{r}0.130 \\
0.139 \\
0.139 \\
0.134 \\
0.133 \\
0.129 \\
0.151 \\
0.136 \\
\pm 0.007\end{array}$ \\
\hline
\end{tabular}


TABLE A-9

THERMAL CONDUCTIVITY OF H-327 GRAPHITE

\begin{tabular}{|c|c|c|c|c|c|c|c|}
\hline \multirow[b]{2}{*}{$\begin{array}{c}\text { Specimen } \\
\text { No. }\end{array}$} & \multirow[b]{2}{*}{ Orientation } & \multirow[b]{2}{*}{$\begin{array}{l}\text { Location } \\
\text { in Log }\end{array}$} & \multicolumn{5}{|c|}{ Thermal Conductivity $\left(\mathrm{cal} / \mathrm{cm}-\mathrm{sec}^{-}{ }^{\circ} \mathrm{C}\right)$} \\
\hline & & & $22^{\circ} \mathrm{C}$ & $200^{\circ} \mathrm{C}$ & $400^{\circ} \mathrm{C}$ & $500^{\circ} \mathrm{C}$ & $800^{\circ} \mathrm{C}$ \\
\hline $\mathrm{L}-0094$ & Perpendicular & $1 / 2$ radius & 0.338 & 0.270 & 0.197 & 0.184 & 0.140 \\
\hline 0095 & & & 0.330 & 0.264 & 0.204 & 0.181 & 0.143 \\
\hline 0096 & & & 0.337 & 0.269 & 0.202 & 0.180 & 0.142 \\
\hline 0097 & & & 0.336 & 0.274 & 0.209 & 0.197 & 0.141 \\
\hline 0098 & & & 0.325 & 0.248 & 0.197 & 0.182 & 0.138 \\
\hline \multirow[t]{3}{*}{0099} & & & 0.321 & 0.245 & 0.195 & 0.175 & 0.136 \\
\hline & & & $\overline{0.331}$ & $\overline{0.262}$ & $\overline{0.201}$ & $\overline{0.183}$ & $\overline{0.140}$ \\
\hline & & & \pm 0.007 & \pm 0.012 & \pm 0.005 & \pm 0.007 & \pm 0.003 \\
\hline$L-0101$ & Paralle1 & $1 / 2$ radius & 0.451 & 0.384 & 0.299 & 0.269 & 0.193 \\
\hline 0102 & & & 0.443 & 0.352 & 0.267 & 0.242 & 0.186 \\
\hline 0103 & & & 0.444 & 0.377 & 0.311 & 0.276 & 0.187 \\
\hline 0104 & & & 0.470 & 0.375 & 0.300 & 0.276 & 0.191 \\
\hline 0105 & & & 0.417 & 0.353 & 0.284 & 0.264 & 0.203 \\
\hline \multirow[t]{3}{*}{0100} & & & 0.472 & 0.363 & $\underline{0.295}$ & 0.275 & 0.202 \\
\hline & & & 0.450 & 0.367 & 0.293 & 0.267 & 0.194 \\
\hline & & & \pm 0.020 & \pm 0.013 & \pm 0.015 & \pm 0.013 & \pm 0.007 \\
\hline
\end{tabular}


TABLE A-10

TENSILE PROPERTIES OF H-451 GRAPHITE

(0.505-in.-diameter x 4-in.-1ong samples)

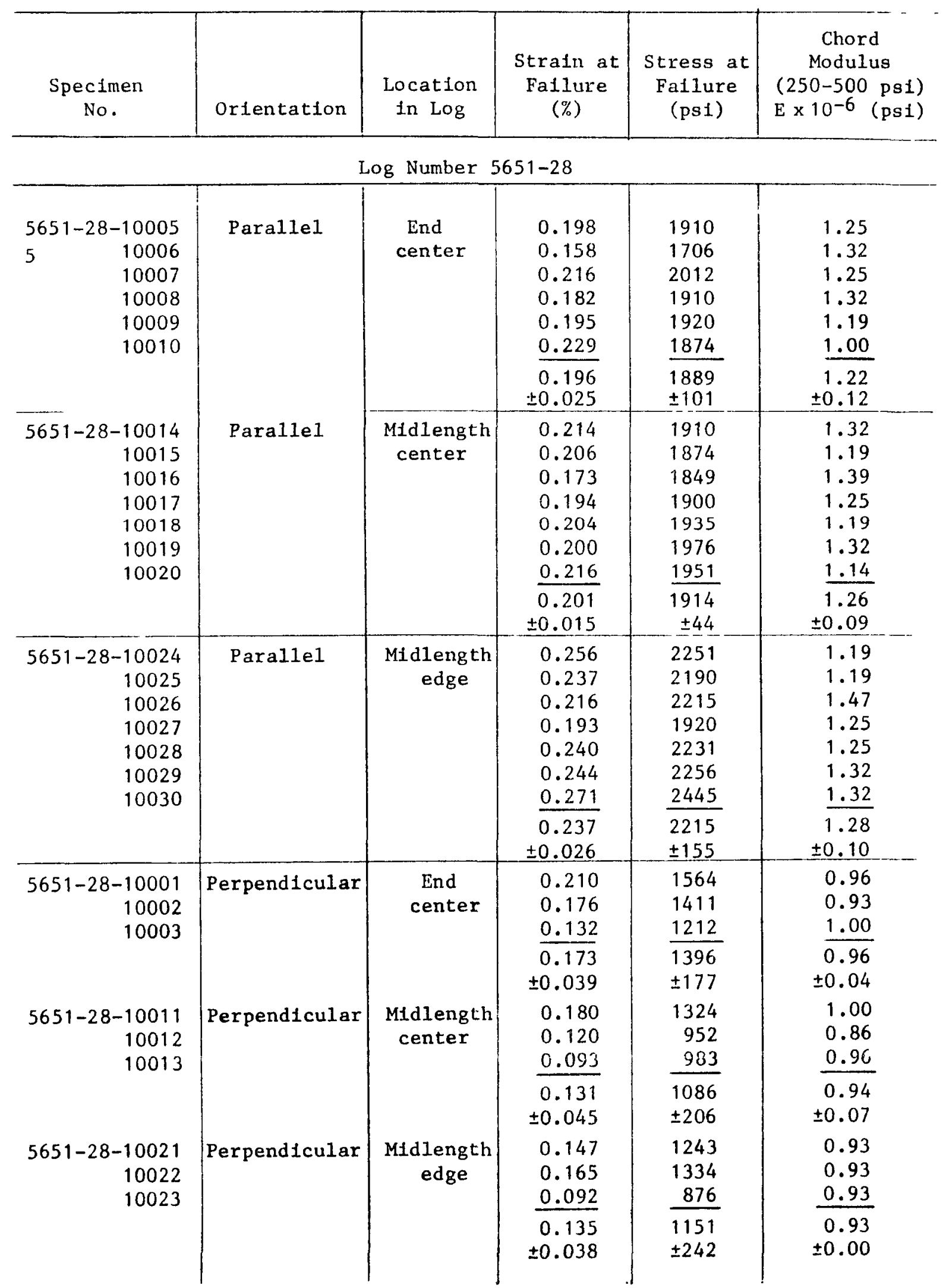


TABLE. $\Lambda-10$ (Continued)

\begin{tabular}{|c|c|c|c|c|c|}
\hline $\begin{array}{c}\text { Specimen } \\
\text { No. }\end{array}$ & Orientation & $\begin{array}{l}\text { Location } \\
\text { in Log }\end{array}$ & $\begin{array}{l}\text { Strain at } \\
\text { Failure } \\
(\%)\end{array}$ & $\begin{array}{l}\text { Stress at } \\
\text { Failure } \\
\text { (psi) }\end{array}$ & $\begin{array}{c}\text { Chord } \\
\text { Modulus } \\
(250-500 \text { psi) } \\
E \times 10^{-6} \text { (psi) }\end{array}$ \\
\hline \multicolumn{6}{|c|}{ Log Number $5651-58$} \\
\hline $\begin{array}{r}5651-58-10061 \\
10062 \\
10063 \\
10064 \\
10065 \\
10066 \\
10067 \\
10068\end{array}$ & Parallel & $\begin{array}{l}\text { Midlength } \\
\text { center }\end{array}$ & $\begin{array}{r}0.191 \\
0.168 \\
0.174 \\
0.166 \\
0.172 \\
0.130 \\
0.204 \\
0.200 \\
0.176 \\
\pm 0.024 \\
\end{array}$ & $\begin{array}{l}1681 \\
1477 \\
1630 \\
1630 \\
1620 \\
1263 \\
1859 \\
2088 \\
1656 \\
\pm 244 \\
\end{array}$ & $\begin{array}{r}1.14 \\
1.09 \\
1.25 \\
1.19 \\
1.09 \\
1.14 \\
1.25 \\
1.47 \\
1.20 \\
\pm 0.13 \\
\end{array}$ \\
\hline $\begin{array}{r}5651-58-10069 \\
10070 \\
10071 \\
10072 \\
10073 \\
10074 \\
10075\end{array}$ & Perpendicular & $\begin{array}{l}\text { Midlength } \\
\text { center }\end{array}$ & $\begin{array}{r}0.171 \\
0.155 \\
0.120 \\
0.137 \\
0.185 \\
0.205 \\
0.220 \\
0.170 \\
\pm 0.036 \\
\end{array}$ & $\begin{array}{l}1289 \\
1273 \\
1146 \\
1070 \\
1462 \\
1589 \\
1538 \\
1338 \\
\pm 197 \\
\end{array}$ & $\begin{array}{r}0.96 \\
0.96 \\
1.04 \\
0.64 \\
0.93 \\
1.04 \\
0.93 \\
0.93 \\
\pm 0.14 \\
\end{array}$ \\
\hline $\begin{array}{r}5651-58-10076 \\
10077 \\
10078 \\
10079 \\
10080 \\
10081 \\
10082\end{array}$ & Perpendlcular & $\begin{array}{l}\text { Midlength } \\
\text { edge }\end{array}$ & $\begin{array}{r}0.221 \\
0.150 \\
0.160 \\
0.190 \\
0.250 \\
0.225 \\
0.210 \\
0.210 \\
\pm 0.036\end{array}$ & $\begin{array}{l}1716 \\
1304 \\
1401 \\
1492 \\
1905 \\
1716 \\
1665 \\
1600 \\
\pm 209\end{array}$ & $\begin{array}{r}0.93 \\
0.96 \\
0.93 \\
0.93 \\
1.00 \\
0.96 \\
0.96 \\
0.95 \\
\pm 0.03\end{array}$ \\
\hline
\end{tabular}


TABLE A-11

TENSILE PROPERTIES OF H-451 GRAPHITE

(0.25-in.-diameter $\times 0.9$-in.-long samples)

\begin{tabular}{|c|c|c|c|c|c|}
\hline $\begin{array}{c}\text { Specimen } \\
\text { No. }\end{array}$ & Orientation & $\begin{array}{l}\text { Location } \\
\text { in Log }\end{array}$ & $\begin{array}{c}\text { Strain at } \\
\text { Failure } \\
(\%)\end{array}$ & $\begin{array}{c}\text { Stress at } \\
\text { Failure } \\
(p s i)\end{array}$ & $\begin{array}{c}\text { Chord } \\
\text { Modulus } \\
(250-500 \text { psi) } \\
\text { Ex 10-6 (psi) }\end{array}$ \\
\hline \multicolumn{6}{|c|}{ Log Number 5651-28 } \\
\hline $\begin{array}{r}5651-28-10034 \\
10035 \\
10036 \\
10037 \\
10038 \\
10059 \\
10060\end{array}$ & Paralle1 & $\begin{array}{c}\text { End } \\
\text { center }\end{array}$ & $\begin{array}{r}0.233 \\
0.231 \\
0.179 \\
0.163 \\
0.257 \\
0.171 \\
0.212 \\
0.207 \\
\pm 0.036 \\
\end{array}$ & $\begin{array}{l}1691 \\
1670 \\
1732 \\
1548 \\
1966 \\
1283 \\
1711 \\
1657 \\
\pm 207 \\
\end{array}$ & $\begin{array}{r}1.00 \\
1.00 \\
1.25 \\
1.00 \\
1.00 \\
\text { N.A. } \\
\text { N.A. } \\
1.05 \\
+0.11 \\
\end{array}$ \\
\hline $\begin{array}{r}5651-28-10042 \\
10043 \\
10044 \\
10045 \\
10046 \\
10047 \\
10048\end{array}$ & Paralle1 & $\begin{array}{l}\text { Midlength } \\
\text { center }\end{array}$ & $\begin{array}{r}0.202 \\
0.225 \\
0.206 \\
0.238 \\
0.225 \\
0.220 \\
0.154 \\
0.210 \\
\pm 0.028 \\
\end{array}$ & $\begin{array}{r}1681 \\
1752 \\
1803 \\
1966 \\
1772 \\
1874 \\
1721 \\
1796 \\
\pm 97 \\
\end{array}$ & $\begin{array}{r}1.00 \\
1.11 \\
1.18 \\
1.00 \\
1.05 \\
1.33 \\
1.18 \\
1.12 \\
\pm 0.12 \\
\end{array}$ \\
\hline $\begin{array}{r}5651-28-10052 \\
10053 \\
10054 \\
10055 \\
10056 \\
10057 \\
10058\end{array}$ & Para11el & $\begin{array}{c}\text { Midlength } \\
\text { edge }\end{array}$ & $\begin{array}{r}0.294 \\
0.253 \\
0.272 \\
0.280 \\
0.272 \\
0.276 \\
0.303 \\
0.279 \\
\pm 0.016 \\
\end{array}$ & $\begin{array}{r}2322 \\
2118 \\
2220 \\
2220 \\
2200 \\
2241 \\
2404 \\
2246 \\
\pm 92 \\
\end{array}$ & $\begin{array}{r}1.11 \\
1.05 \\
1.18 \\
1.11 \\
1.00 \\
1.18 \\
1.11 \\
1.11 \\
\pm 0.07 \\
\end{array}$ \\
\hline $\begin{array}{r}5651-28-10031 \\
10032 \\
10033\end{array}$ & Perpendicular & $\begin{array}{l}\text { End } \\
\text { center }\end{array}$ & $\begin{array}{r}0.348 \\
0.225 \\
0.235 \\
0.269 \\
\pm 0.068\end{array}$ & $\begin{array}{l}2384 \\
2078 \\
1691 \\
2051 \\
\pm 347\end{array}$ & $\begin{array}{r}1.00 \\
1.25 \\
0.87 \\
1.05 \\
\pm 0.19\end{array}$ \\
\hline $\begin{array}{r}5651-28-10039 \\
10040 \\
10041\end{array}$ & Perpendtcular & $\begin{array}{l}\text { Midlength } \\
\text { center }\end{array}$ & $\begin{array}{r}0.206 \\
0.240 \\
0.245 \\
0.230 \\
\pm 0.021 \\
\end{array}$ & $\begin{array}{r}1487 \\
1548 \\
1640 \\
1558 \\
\pm 77\end{array}$ & $\begin{array}{r}0.83 \\
0.83 \\
0.95 \\
0.87 \\
\pm 0.07 \\
\end{array}$ \\
\hline $\begin{array}{r}5651-28-10049 \\
10050 \\
10051\end{array}$ & Perpend1cular & $\begin{array}{c}\text { Midlength } \\
\text { edge }\end{array}$ & $\begin{array}{r}0.312 \\
0.125 \\
0.247 \\
0.228 \\
\pm 0.095\end{array}$ & $\begin{array}{l}2037 \\
1141 \\
1732 \\
1637 \\
\pm 456\end{array}$ & $\begin{array}{r}0.91 \\
0.95 \\
1.00 \\
0.95 \\
\pm 0.05\end{array}$ \\
\hline
\end{tabular}


TABLE A-12

TENSILE PROPERTIES OF FORT ST. VRAIN PRODUCTION LOGS OF H-327 GRAPHITE

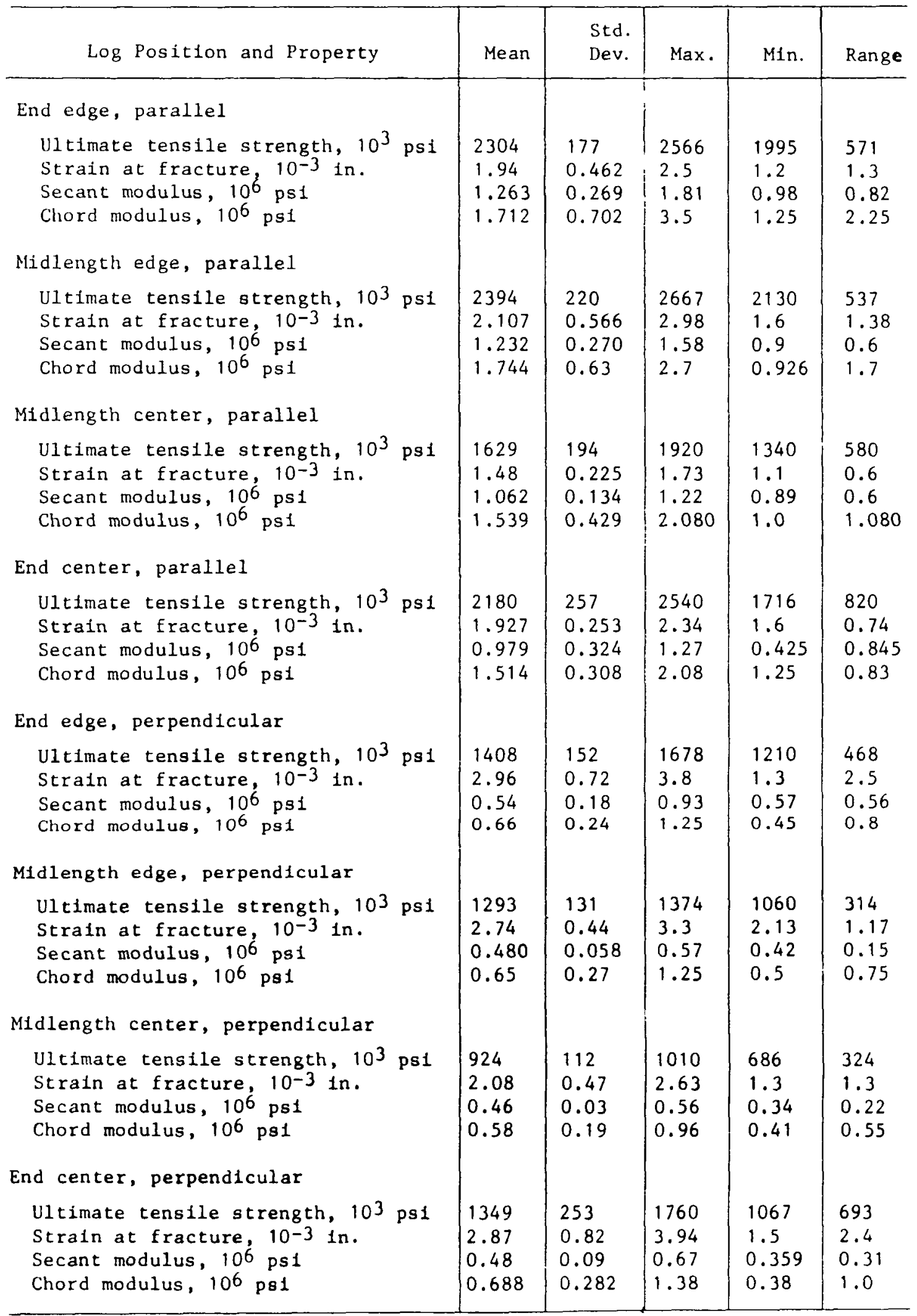


TABLE A-13

CHEMICAL IMPURITIES IN H-451 GRAPHITE

\begin{tabular}{|c|c|c|c|c|c|c|}
\hline \multirow[b]{2}{*}{ Specimen No. } & \multirow[b]{2}{*}{ Location in Log } & \multicolumn{5}{|c|}{ Spectrographic Analysis (ppm) } \\
\hline & & B & $\mathrm{Fe}$ & $\mathrm{V}$ & $\mathrm{Ti}$ & Ash \\
\hline \multirow[t]{2}{*}{$\begin{array}{l}30434-1 \\
30434-2\end{array}$} & Midlength center & $\begin{array}{l}1 \\
2 \\
\end{array}$ & $\begin{array}{r}4 \\
10 \\
\end{array}$ & $\begin{array}{l}20 \\
80 \\
\end{array}$ & $\begin{array}{r}8 \\
10\end{array}$ & $\begin{array}{l}530 \\
270\end{array}$ \\
\hline & Average & 1.5 & 7 & 50 & 9 & 400 \\
\hline \multirow[t]{2}{*}{$\begin{array}{l}30434-3 \\
30434-4\end{array}$} & Midlength edge & $\begin{array}{l}4 \\
5\end{array}$ & $\begin{array}{l}2 \\
4\end{array}$ & $\begin{array}{l}<4 \\
<4\end{array}$ & $\begin{array}{l}4 \\
2\end{array}$ & $\begin{array}{l}440 \\
490\end{array}$ \\
\hline & Average & $\overline{4.5}$ & 3 & $<4$ & 3 & 465 \\
\hline \multirow[t]{3}{*}{$\begin{array}{l}30434-5 \\
30434-6\end{array}$} & End edge & $\begin{array}{l}3 \\
2 \\
\end{array}$ & $\begin{array}{l}4 \\
4 \\
\end{array}$ & $\begin{array}{l}<4 \\
<4 \\
\end{array}$ & $\begin{array}{l}4 \\
1 \\
\end{array}$ & $\begin{array}{l}230 \\
360 \\
\end{array}$ \\
\hline & Average & 2.5 & 4 & $<4$ & 2.5 & 295 \\
\hline & $\begin{array}{l}\text { Average for whole } \\
\text { log }\end{array}$ & 3 & 5 & 18 & 5 & 385 \\
\hline
\end{tabular}


TABLE A-14

CHEMICAL IMPURITIES IN TS-1240 GRAPHITE

\begin{tabular}{|c|c|c|c|c|c|c|}
\hline \multirow[b]{2}{*}{ Specimen No. } & \multirow[b]{2}{*}{ Location in $\mathrm{Log}$} & \multicolumn{5}{|c|}{ Spectrographic Analysis (ppm) } \\
\hline & & $B$ & $\mathrm{Fe}$ & $\mathrm{v}$ & $\mathrm{Ti}$ & Ash \\
\hline \multirow[t]{2}{*}{$\begin{array}{l}5651-75-3 A-82 \\
5651-75-3 B-94 \\
5651-72-3 A-82 \\
5651-72-3 B-94\end{array}$} & Midlength center & $\begin{array}{c}<0.5 \\
<0.5 \\
1 \\
1 \\
\end{array}$ & $\begin{array}{l}<10 \\
<10 \\
<10 \\
<10 \\
\end{array}$ & $\begin{array}{l}10 \\
10 \\
20 \\
10 \\
\end{array}$ & $\begin{array}{l}20 \\
20 \\
20 \\
20 \\
\end{array}$ & $\begin{array}{r}95 \\
81 \\
94 \\
120 \\
\end{array}$ \\
\hline & Average & $<1$ & $<10$ & 12.5 & 20 & 98 \\
\hline \multirow[t]{2}{*}{$\begin{array}{l}5651-75-3 B-165 \\
5651-75-3 A-156 \\
5651-72-3 A-156 \\
5651-72-3 B-165\end{array}$} & Midlength edge & $\begin{array}{c}<0.5 \\
<0.5 \\
1 \\
1 \\
\end{array}$ & $\begin{array}{l}<10 \\
<10 \\
<10 \\
<10 \\
\end{array}$ & $\begin{array}{l}10 \\
20 \\
10 \\
10 \\
\end{array}$ & $\begin{array}{l}20 \\
20 \\
10 \\
10 \\
\end{array}$ & $\begin{array}{r}47 \\
74 \\
140 \\
92 \\
\end{array}$ \\
\hline & Average & $<1$ & $<10$ & 12.5 & 15 & 88 \\
\hline \multirow[t]{2}{*}{$\begin{array}{l}5651-75-1 \mathrm{~B}-115 \\
5651-75-1 \mathrm{~A}-106 \\
5651-72-1 \mathrm{~B}-115 \\
5651-72-1 \mathrm{~A}-106\end{array}$} & End edge & $\begin{array}{l}<0.5 \\
<0.5 \\
<0.5 \\
<0.5 \\
\end{array}$ & $\begin{array}{l}<10 \\
<10 \\
<10 \\
<10 \\
\end{array}$ & $\begin{array}{l}20 \\
10 \\
10 \\
10 \\
\end{array}$ & $\begin{array}{l}20 \\
10 \\
10 \\
10 \\
\end{array}$ & $\begin{array}{r}39 \\
58 \\
120 \\
110 \\
\end{array}$ \\
\hline & Average & $<0.5$ & $<10$ & 12.5 & 12.5 & 82 \\
\hline \multirow[t]{2}{*}{$\begin{array}{l}5651-75-1 \mathrm{~B}-43 \\
5651-75-1 \mathrm{~A}-31 \\
5651-72-1 \mathrm{~B}-43 \\
5651-72-1 \mathrm{~A}-31\end{array}$} & End center & $\begin{array}{c}<0.5 \\
<0.5 \\
1 \\
1 \\
\end{array}$ & $\begin{array}{l}<10 \\
<10 \\
<10 \\
<10 \\
\end{array}$ & $\begin{array}{l}20 \\
10 \\
10 \\
20 \\
\end{array}$ & $\begin{array}{l}20 \\
20 \\
10 \\
20 \\
\end{array}$ & $\begin{array}{l}89 \\
55 \\
69 \\
68 \\
\end{array}$ \\
\hline & Average & $<1$ & $<10$ & 15 & 17.5 & 70 \\
\hline
\end{tabular}


TABLE A-15

CHEMICAL IMPURITIES IN $\mathrm{P}_{3}$ JHAN GRAPHITE

\begin{tabular}{c|c|c|c|c|c|c}
\hline \multirow{2}{*}{ Specimen No. } & \multirow{2}{*}{ Location in Log } & \multicolumn{3}{|c|}{ Spectrographic Analysis (ppm) } \\
\cline { 3 - 6 } $31281-1$ & Not available & 0.5 & 4 & 4 & $<1$ & 100 \\
$31282-2$ & Average & $\frac{0.5}{0.5}$ & $\frac{4}{4}$ & $\frac{2}{3}$ & $\frac{<1}{<1}$ & $\frac{30}{65}$ \\
\hline
\end{tabular}


TABLE A-16

DIMENSIONAL CHANGES OF NEEDLE-COKE H-327 GRAPHITE

FROM CAPSULE OG-1

AXIAL (PARALLEL) ORIENTATION

\begin{tabular}{|c|c|c|c|c|}
\hline $\begin{array}{c}\text { Record } \\
\text { No. }\end{array}$ & $\begin{array}{l}\text { Dimensional } \\
\text { Change } \\
\ln \left(1+\frac{\Delta L}{L}\right) \quad(\%)\end{array}$ & $\begin{array}{c}\text { Total } \\
\text { Fluence } \times 10^{-21} \\
\left(\mathrm{n} / \mathrm{cm}^{2}\right)(\mathrm{E}>0.18 \mathrm{MeV})\end{array}$ & $\begin{array}{l}\text { Average } \\
\text { Irradiation } \\
\text { Temperature } \\
\quad\left({ }^{\circ} \mathrm{C}\right)\end{array}$ & $\begin{array}{c}\text { Previous } \\
\text { Record } \\
\text { No. }\end{array}$ \\
\hline $\begin{array}{l}5005 \\
5009 \\
5013 \\
5017 \\
5021 \\
5025 \\
5029 \\
5033 \\
5037 \\
5041 \\
5114 \\
5115 \\
5118 \\
5119 \\
5124 \\
5125 \\
5128 \\
5129 \\
5134 \\
5135 \\
5147 \\
5151 \\
5155 \\
5159 \\
5163 \\
5167 \\
5171 \\
5175 \\
5179 \\
5182 \\
5185 \\
5186 \\
5195 \\
5196 \\
5205 \\
5215 \\
5216 \\
5241 \\
5242 \\
5251\end{array}$ & $\begin{array}{l}-0.15 \\
-0.16 \\
-0.17 \\
-0.14 \\
-0.11 \\
-0.13 \\
-0.11 \\
-0.15 \\
-0.20 \\
-0.18 \\
-0.14 \\
-0.16 \\
-0.16 \\
-0.20 \\
-0.15 \\
-0.21 \\
-0.14 \\
-0.18 \\
-0.14 \\
-0.20 \\
-0.25 \\
-0.24 \\
-0.17 \\
-0.24 \\
-0.26 \\
-0.20 \\
-0.23 \\
-0.17 \\
-0.24 \\
-0.28 \\
-0.24 \\
-0.17 \\
-0.25 \\
-0.10 \\
-0.25 \\
-0.22 \\
-0.23 \\
-0.28 \\
-0.33 \\
-0.28\end{array}$ & $\begin{array}{l}2.2 \\
2.9 \\
1\end{array}$ & | & \\
\hline
\end{tabular}


TABLE A-16 (Continued)

\begin{tabular}{|c|c|c|c|c|}
\hline $\begin{array}{c}\text { Record } \\
\text { No. }\end{array}$ & $\begin{array}{l}\text { Dimensional } \\
\text { Change } \\
\ln \left(1+\frac{\Delta \mathrm{L}}{\mathrm{L}_{0}}\right)\end{array}$ & $\begin{array}{c}\text { Total } \\
\text { Fluence } \times 10^{-21} \\
\left(\mathrm{n} / \mathrm{cm}^{2}\right)(\mathrm{E}>0.18 \mathrm{MeV})\end{array}$ & $\begin{array}{c}\text { Average } \\
\text { Irradiation } \\
\text { Temperature } \\
\left({ }^{\circ} \mathrm{C}\right)\end{array}$ & $\begin{array}{c}\text { Previous } \\
\text { Record } \\
\text { No. }\end{array}$ \\
\hline $\begin{array}{l}5252 \\
5257 \\
5258 \\
5261 \\
5262 \\
5263 \\
5264 \\
5267 \\
5268 \\
5271 \\
5272 \\
5273 \\
5274 \\
5277 \\
5278 \\
5281 \\
5282 \\
5291 \\
5292 \\
5466 \\
5467 \\
5473 \\
5474 \\
5477 \\
5478 \\
5509 \\
5510 \\
5511 \\
5513 \\
5514 \\
5523 \\
5524 \\
5533 \\
5534 \\
5543 \\
5544 \\
5546 \\
5547 \\
5550 \\
5551 \\
5555 \\
5556 \\
5557\end{array}$ & $\begin{array}{l}-0.31 \\
-0.24 \\
-0.34 \\
-0.32 \\
-0.27 \\
-0.34 \\
-0.33 \\
-0.25 \\
-0.21 \\
-0.29 \\
-0.27 \\
-0.21 \\
-0.33 \\
-0.31 \\
-0.28 \\
-0.20 \\
-0.28 \\
-0.33 \\
-0.28 \\
-0.62 \\
-0.50 \\
-0.65 \\
-0.54 \\
-0.69 \\
-0.53 \\
-0 \\
-0.93\end{array}$ & $j^{2.9}$ & \begin{tabular}{|}
$\mid$ \\
$\downarrow$ \\
1040 \\
110 \\
1255 \\
1220 \\
1220 \\
1185 \\
1040 \\
1040
\end{tabular} & $\begin{array}{l}2914 \\
2920 \\
2906\end{array}$ \\
\hline
\end{tabular}


TABLE A-16 (Continued)

\begin{tabular}{|c|c|c|c|c|}
\hline $\begin{array}{c}\text { Record } \\
\text { No. }\end{array}$ & $\begin{array}{l}\text { Dimensional } \\
\text { Change } \\
\ln \left(1+\frac{\Delta \mathrm{L}}{\mathrm{L}_{0}}\right)(\%)\end{array}$ & $\begin{array}{c}\text { Total } \\
\text { Fluence } \times 10^{-21} \\
\left(\mathrm{n} / \mathrm{cm}^{2}\right)(\mathrm{E}>0.18 \mathrm{MeV})\end{array}$ & $\begin{array}{c}\text { Average } \\
\text { Irradiation } \\
\text { Temperature } \\
\left({ }^{\circ} \mathrm{C}\right)\end{array}$ & $\begin{array}{l}\text { Previous } \\
\text { Record } \\
\text { No. }\end{array}$ \\
\hline $\begin{array}{l}5560 \\
5561 \\
5566 \\
5567 \\
5568 \\
5569 \\
5629 \\
5738 \\
5748 \\
5758 \\
5766 \\
5771 \\
5775 \\
5779 \\
5784 \\
5791 \\
5797 \\
5804 \\
5811 \\
5815 \\
5819 \\
5823 \\
5856 \\
5857 \\
5860 \\
5861 \\
5864 \\
5865 \\
5907 \\
5911 \\
5915 \\
5919 \\
5923 \\
5927 \\
5954 \\
5955 \\
5958 \\
5959 \\
5965 \\
5974 \\
5975 \\
5996 \\
5997\end{array}$ & $\begin{array}{l}-4.60 \\
-4.01 \\
-1.22 \\
-1.32 \\
-1.29 \\
-1.47 \\
-7.73 \\
-1.31 \\
-1.18 \\
-1.11 \\
-1.30 \\
-0.83 \\
-0.88 \\
-0.83 \\
-0.77 \\
-0.71 \\
-0.71 \\
-1.09 \\
-0.91 \\
-1.07 \\
-1.00 \\
-1.00 \\
-0.79 \\
-0.78 \\
-0.72 \\
-0.72 \\
-0.75 \\
-0.70 \\
-0.60 \\
-0.49 \\
-0.52 \\
-0.56 \\
-0.52 \\
-0.51 \\
-0.42 \\
-0.34 \\
-1.31 \\
-1.30 \\
-0.30 \\
-0.43 \\
-0.43 \\
-0.33 \\
-0.25\end{array}$ & 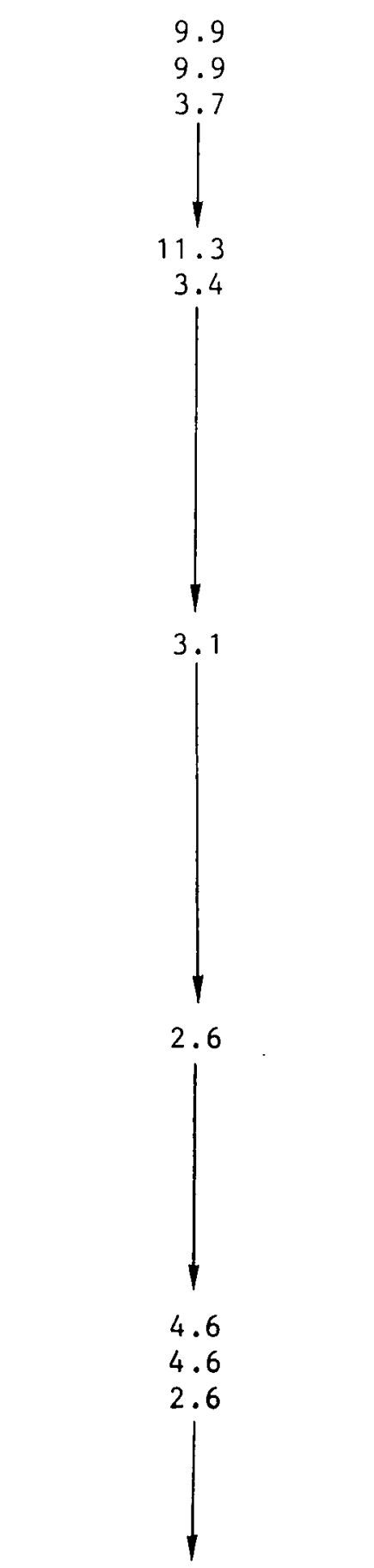 & 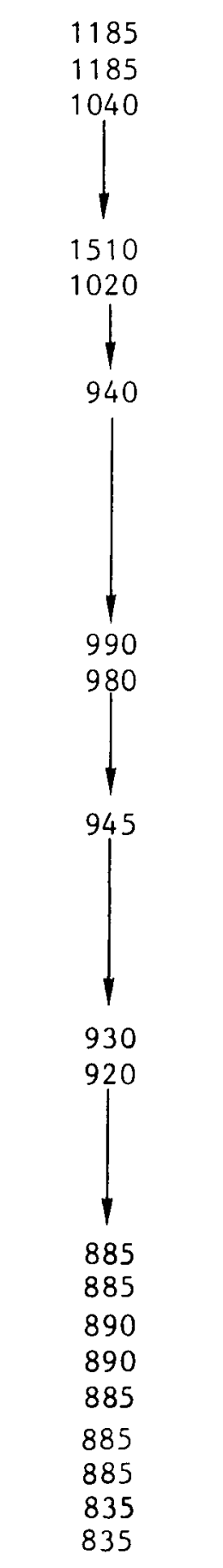 & $\begin{array}{l}2450 \\
2407 \\
2842\end{array}$ \\
\hline
\end{tabular}


TABLE A-16 (Continued)

\begin{tabular}{|c|c|c|c|c|}
\hline $\begin{array}{c}\text { Record } \\
\text { No. }\end{array}$ & $\begin{array}{l}\text { Dimensional } \\
\text { Change } \\
\ln \left(1+\frac{\Delta \mathrm{L}}{\mathrm{L}}\right)(\%)\end{array}$ & $\begin{array}{c}\text { Total } \\
\text { Fluence } \times 10^{-21} \\
\left(\mathrm{n} / \mathrm{cm}^{2}\right)(\mathrm{E}>0.18 \mathrm{MeV})\end{array}$ & $\begin{array}{c}\text { Average } \\
\text { Irradiation } \\
\text { Temperature } \\
\left({ }^{\circ} \mathrm{C}\right)\end{array}$ & $\begin{array}{l}\text { Previous } \\
\text { Record } \\
\text { No. }\end{array}$ \\
\hline $\begin{array}{l}6006 \\
6007 \\
6008 \\
6009 \\
6018 \\
6019 \\
6024 \\
6025 \\
6028 \\
6029 \\
6030 \\
6031 \\
6034 \\
6035 \\
6038 \\
6039 \\
6092 \\
6093 \\
6102 \\
6103 \\
6112 \\
6113 \\
6122 \\
6123 \\
6148 \\
6149 \\
6158 \\
6159 \\
6168 \\
6169 \\
6178 \\
6179 \\
6188 \\
6189 \\
6198 \\
6199 \\
6209 \\
6213 \\
6217 \\
6221 \\
6225 \\
6229 \\
6233\end{array}$ & $\begin{array}{l}-0.29 \\
-0.20 \\
-0.31 \\
-0.20 \\
-0.27 \\
-0.16 \\
-0.32 \\
-0.27 \\
-0.29 \\
-0.20 \\
-0.26 \\
-0.28 \\
-0.27 \\
-0.30 \\
-0.64 \\
-0.20 \\
-0.17 \\
-0.11 \\
-0.15 \\
-0.11 \\
-0.15 \\
-0.12 \\
-0.05 \\
-0.11 \\
-0.15 \\
-0.18 \\
-0.11 \\
-0.07 \\
-0.18 \\
-0.09 \\
-0.12 \\
-0.15 \\
-0.13 \\
-0.13 \\
-0.15 \\
-0.08 \\
-0.06 \\
-0.09 \\
-0.12 \\
-0.11 \\
-0.24 \\
-0.10 \\
-0.16\end{array}$ & 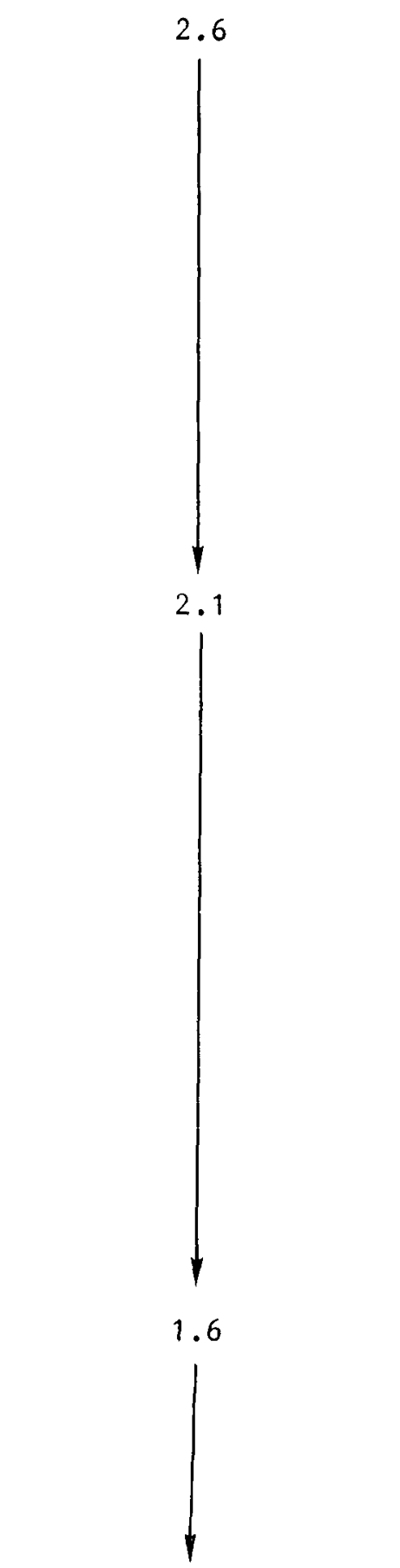 & $\mid$ & \\
\hline
\end{tabular}


TABLE A-16 (Continued)

\begin{tabular}{|c|c|c|c|c|}
\hline $\begin{array}{c}\text { Record } \\
\text { No. }\end{array}$ & $\begin{array}{l}\text { Dimensional } \\
\text { Change } \\
\ln \left(1+\frac{\Delta \mathrm{L}}{\mathrm{L}_{0}}\right)(\%)\end{array}$ & $\begin{array}{c}\text { Total } \\
\text { Fluence } \times 10^{-21} \\
\left(\mathrm{n} / \mathrm{cm}^{2}\right)(\mathrm{E}>0.18 \mathrm{MeV})\end{array}$ & $\begin{array}{c}\text { Average } \\
\text { Irradiation } \\
\text { Temperature } \\
\left({ }^{\circ} \mathrm{C}\right)\end{array}$ & $\begin{array}{l}\text { Previous } \\
\text { Record } \\
\text { No. }\end{array}$ \\
\hline $\begin{array}{l}6237 \\
6241 \\
6246 \\
6250 \\
6251 \\
6254 \\
6255 \\
6260 \\
6261 \\
6264 \\
6265 \\
6301\end{array}$ & $\begin{array}{l}-0.15 \\
-0.10 \\
-0.41 \\
-0.34 \\
-0.20 \\
-0.37 \\
-0.25 \\
-0.40 \\
-0.19 \\
-0.43 \\
-0.34 \\
-0.15\end{array}$ & $\begin{array}{c}1.6 \\
1.6 \\
2.4 \\
1 \\
1.6\end{array}$ & $\begin{array}{c}645 \\
645 \\
625 \\
\mid \\
595\end{array}$ & $\begin{array}{l}2465 \\
2458 \\
2410 \\
2472 \\
2457 \\
2493 \\
2435 \\
2474 \\
2698\end{array}$ \\
\hline
\end{tabular}


TABLE A-17

DIMENSIONAL CHANGES OF NEEDLE-COKE H-327 GRAPHITE

FROM CAPSULE OG-1

RADIAL (PERPENDICULAR) ORIENTATION

\begin{tabular}{|c|c|c|c|c|}
\hline $\begin{array}{c}\text { Record } \\
\text { No. }\end{array}$ & $\begin{array}{l}\text { Dimensional } \\
\text { Change } \\
\ln \left(1+\frac{\Delta \mathrm{L}}{\mathrm{L}_{0}}\right)(\%)\end{array}$ & $\begin{array}{c}\text { Total } \\
\text { Fluence } \times 10^{-21} \\
\left(\mathrm{n} / \mathrm{cm}^{2}\right)(\mathrm{E}>0.18 \mathrm{MeV})\end{array}$ & $\begin{array}{c}\text { Average } \\
\text { Irradiation } \\
\text { Temperature } \\
\left({ }^{\circ} \mathrm{C}\right)\end{array}$ & $\begin{array}{c}\text { Previous } \\
\text { Record } \\
\text { No. }\end{array}$ \\
\hline $\begin{array}{l}5007 \\
5011 \\
5015 \\
5019 \\
5023 \\
5027 \\
5031 \\
5035 \\
5039 \\
5043 \\
5116 \\
5117 \\
5120 \\
5121 \\
5126 \\
5127 \\
5130 \\
5131 \\
5136 \\
5137 \\
5149 \\
5153 \\
5157 \\
5161 \\
5165 \\
5169 \\
5173 \\
5177 \\
5181 \\
5184 \\
5206 \\
5259 \\
5260 \\
5265 \\
5266 \\
5269 \\
5270 \\
5275 \\
5276 \\
5279\end{array}$ & $\begin{array}{l}-0.12 \\
-0.12 \\
-0.11 \\
-0.10 \\
-0.06 \\
-0.08 \\
-0.08 \\
-0.16 \\
-0.14 \\
-0.16 \\
-0.16 \\
-0.08 \\
-0.14 \\
-0.35 \\
-0.19 \\
-0.19 \\
-0.19 \\
-0.14 \\
-0.26 \\
-0.17 \\
-0.13 \\
-0.16 \\
-0.17 \\
09.14 \\
-0.10 \\
-0.11 \\
-0.16 \\
-0.04 \\
-0.24 \\
-0.19 \\
-0.21 \\
-0.26 \\
-0.28 \\
-0.16 \\
-0.19 \\
-0.22 \\
-0.23 \\
-0.20 \\
-0.21 \\
-0.26\end{array}$ & $\left.\right|^{2.2}$ & 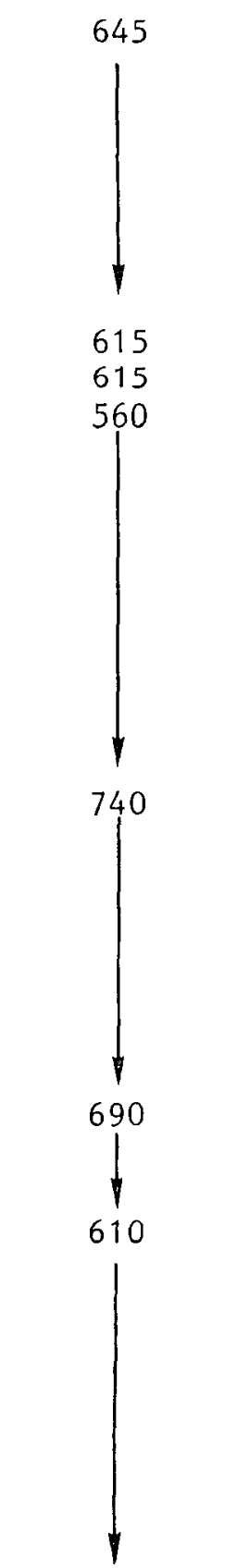 & \\
\hline
\end{tabular}


TABLE A-17 (Continued)

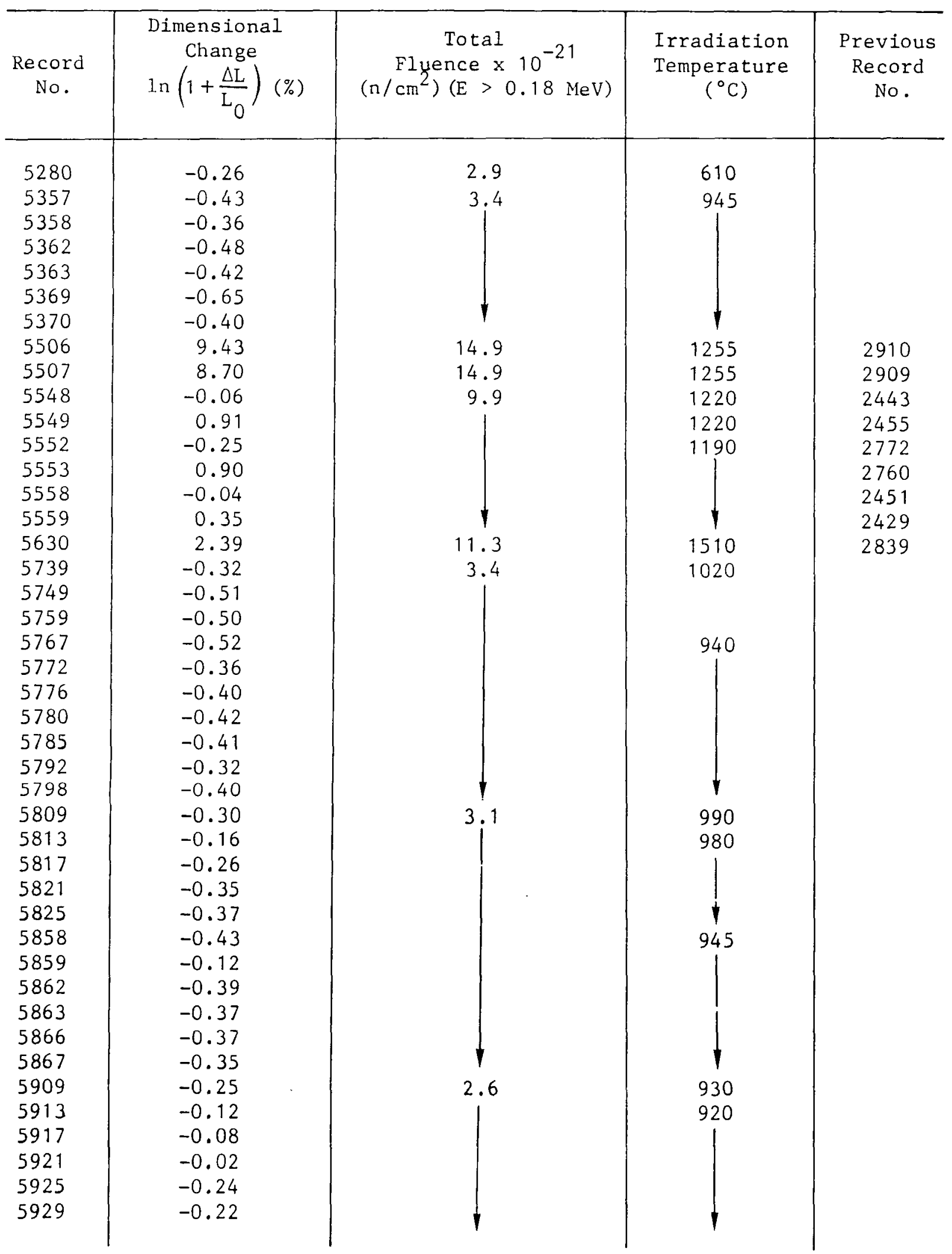




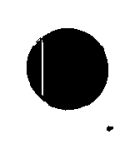

TABLE A-17 (Continued)

\begin{tabular}{|c|c|c|c|c|}
\hline $\begin{array}{c}\text { Record } \\
\text { No. }\end{array}$ & $\begin{array}{l}\text { Dimensional } \\
\quad \text { Change } \\
\ln \left(1+\frac{\Delta \mathrm{L}}{\mathrm{L}_{0}}\right)\end{array}$ & $\begin{array}{c}\text { Total } \\
\text { F1uence } \times 10^{-21} \\
\left(\mathrm{n} / \mathrm{cm}^{2}\right)(\mathrm{E}>0.18 \mathrm{MeV})\end{array}$ & $\begin{array}{c}\text { Average } \\
\text { Irradiation } \\
\text { Temperature } \\
\left({ }^{\circ} \mathrm{C}\right)\end{array}$ & $\begin{array}{c}\text { Previous } \\
\text { Record } \\
\text { No. }\end{array}$ \\
\hline $\begin{array}{l}5956 \\
5957 \\
6026 \\
6027 \\
6032 \\
6033 \\
6036 \\
6037 \\
6211 \\
6215 \\
6219 \\
6223 \\
6227 \\
6231 \\
6235 \\
6239 \\
6243 \\
6244 \\
6245 \\
6248 \\
6249 \\
6252 \\
6253 \\
6258 \\
6259 \\
6262 \\
6263 \\
6303\end{array}$ & $\begin{array}{l}-0.79 \\
-0.59 \\
-0.19 \\
-0.12 \\
-0.23 \\
-0.02 \\
-0.14 \\
-0.08 \\
-0.06 \\
-0.12 \\
-0.07 \\
-0.04 \\
-0.06 \\
-0.04 \\
-0.09 \\
-0.05 \\
-0.06 \\
-0.54 \\
-0.31 \\
-0.39 \\
-0.33 \\
-0.46 \\
-0.33 \\
-0.46 \\
-0.25 \\
-0.43 \\
-0.29 \\
-0.06\end{array}$ & $\left.\right|^{4.6}$ & 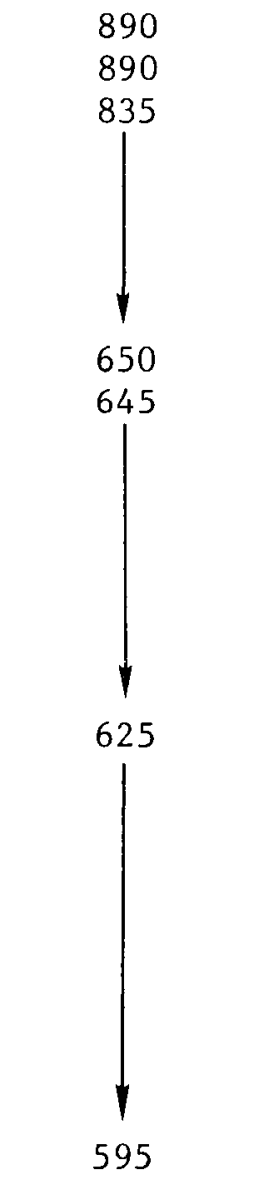 & $\begin{array}{l}2638 \\
2552\end{array}$ \\
\hline
\end{tabular}


]ABLE $A-18$

IHLRMAL LAPANSIVITY OF H-327 GRAPHITL SPECIMHS IRRNIATED IN CAPSULL OG-1

\begin{tabular}{|c|c|c|c|c|c|c|}
\hline $\begin{array}{c}\text { Specimen } \\
\text { No. }\end{array}$ & $\begin{array}{l}\text { Orientation } \\
\text { and } \\
\text { Location (a) }\end{array}$ & $\begin{array}{c}\text { Crucible } \\
\text { No. }\end{array}$ & $\begin{array}{c}\text { Hole } \\
\text { No. }\end{array}$ & $\begin{array}{l}\text { Mean } \\
\text { Irradiation } \\
\text { Temperature } \\
\left({ }^{\circ} \mathrm{C}\right)\end{array}$ & $\begin{array}{c}\text { Fluence } \times 10^{-21} \\
\left(\mathrm{n} / \mathrm{cm}^{2}\right) \\
(\mathrm{E}>0.18 \mathrm{MeV})\end{array}$ & $\begin{array}{l}\text { Coefficient } \\
\text { of Thermal } \\
\text { Expansivity, } \\
\alpha \times 10^{6} \mathrm{C}^{-1} \\
\left(22^{\circ}-500^{\circ} \mathrm{C}\right)\end{array}$ \\
\hline 1 & $C$ para & 1 & 2 & 640 & 2.2 & 1.84 \\
\hline 2 & C para & & 3 & 640 & & 1.87 \\
\hline 201 & E para & & 40 & 580 & & 1.72 \\
\hline 202 & E para & I & 40 & 580 & & 1.65 \\
\hline 101 & $C$ perp & 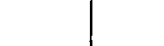 & 2 & 640 & & 3.47 \\
\hline 102 & $C$ perp & 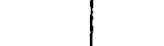 & 3 & 640 & & 3.25 \\
\hline 251 & E perp & & 40 & 580 & & 3.55 \\
\hline 252 & $E$ perp & 1 & 40 & 580 & 1 & 3.54 \\
\hline 222 & E para & 7 & 2 & 980 & 3.1 & 1.97 \\
\hline 223 & E para & 1 & 3 & & & 1.96 \\
\hline 224 & E para & & 4 & & & 1.93 \\
\hline 272 & E perp & & 2 & & & 3.10 \\
\hline 273 & E perp & & 3 & & & 3.38 \\
\hline 274 & $E$ perp & 1 & 4 & 1 & 1 & 3.27 \\
\hline 176 & C para & 8 & 19 & $875-890$ & 3.4 & 2.03 \\
\hline 177 & E para & & 19 & & & 2.27 \\
\hline 174 & $C$ perp & & 19 & & & 3.18 \\
\hline 175 & $E$ perp & 1 & 19 & 1 & 1 & 3.70 \\
\hline
\end{tabular}

(a) $C=$ center,$E=$ edge; para = parallel, perp = perpendicular. 
TABLE A-19

TIERMAL EXPANSIVITY OF H-429 AND H-451 GRAPHITE SPECIMENS IRRADIATED IN CAPSULE OG-1

\begin{tabular}{|c|c|c|c|c|c|c|c|}
\hline $\begin{array}{l}\text { Graphite } \\
\text { Grade }\end{array}$ & $\begin{array}{c}\text { Specimen } \\
\text { No. }\end{array}$ & $\begin{array}{c}\log \\
\text { Location and } \\
\text { Oryentation }(a)\end{array}$ & $\begin{array}{c}\text { Crucible } \\
\text { No. }\end{array}$ & $\begin{array}{l}\text { Hole } \\
\text { No. }\end{array}$ & $\begin{array}{c}\text { Mean } \\
\text { Irrad1ation } \\
\text { Temperature } \\
\left({ }^{\circ} \mathrm{C}\right)\end{array}$ & $\begin{array}{c}\text { Fluence } \times 10^{-21} \\
\left(\mathrm{n} / \mathrm{cm}^{2}\right) \\
(E>0.18 \mathrm{MeV})\end{array}$ & $\begin{array}{c}\text { Coeffictent of } \\
\text { Thermal } \\
\text { Expansivity, } \\
\alpha \times 10^{6} \mathrm{C}^{-1} \\
\left(22^{\circ}-500^{\circ} \mathrm{C}\right)\end{array}$ \\
\hline $\mathrm{H}-45 \mathrm{I}$ & $\begin{array}{l}303 \\
304 \\
305 \\
428 \\
429 \\
430 \\
613 \\
614 \\
615 \\
713 \\
714 \\
715 \\
371 \\
372 \\
373 \\
496 \\
497 \\
498\end{array}$ & $\begin{array}{l}\text { C para } \\
C \text { para } \\
C \text { para } \\
C \text { perp } \\
C \text { perp } \\
C \text { perp } \\
E \text { para } \\
E \text { para } \\
E \text { para } \\
\text { E perp } \\
E \text { perp } \\
E \text { perp } \\
C \text { para } \\
C \text { para } \\
C \text { para } \\
C \text { perp } \\
C \text { perp } \\
C \text { perp }\end{array}$ & $\begin{array}{l}1 \\
1 \\
9 \\
1 \\
1 \\
8 \\
1\end{array}$ & $\begin{array}{l}2 \\
3 \\
4 \\
2 \\
3 \\
4 \\
2 \\
3 \\
4 \\
2 \\
3 \\
4 \\
7 \\
7 \\
8 \\
7 \\
7 \\
8\end{array}$ & $\left.\right|_{1} ^{850}$ & $\sum_{i}^{2.2}$ & $\begin{array}{l}3.98 \\
3.80 \\
3.72 \\
4.82 \\
4.89 \\
4.73 \\
3.92 \\
3.83 \\
4.09 \\
5.04 \\
4.85 \\
4.78 \\
3.52 \\
3.75 \\
3.61 \\
4.39 \\
4.15 \\
4.16\end{array}$ \\
\hline$H-429$ & $\begin{array}{l}389 \\
390 \\
391 \\
419 \\
420 \\
421\end{array}$ & $\begin{array}{l}\text { Para } \\
\text { Para } \\
\text { Para } \\
\text { Perp } \\
\text { Perp } \\
\text { Perp }\end{array}$ & 8 & $\begin{array}{l}16 \\
16 \\
16 \\
15 \\
15 \\
15\end{array}$ & 1 & $i^{3.4}$ & $\begin{array}{l}3.70 \\
3.90 \\
4.06 \\
4.93 \\
5.19 \\
5.16\end{array}$ \\
\hline $\mathrm{H}-451$ & $\begin{array}{l}596 \\
597 \\
598 \\
696 \\
697 \\
698 \\
583 \\
584 \\
585 \\
683 \\
684 \\
685\end{array}$ & $\begin{array}{l}\text { E para } \\
\text { E para } \\
\text { E para } \\
\text { E perp } \\
\text { E perp } \\
\text { E perp } \\
\text { E para } \\
\text { E para } \\
\text { E para } \\
\text { E perp } \\
\text { E perp } \\
\text { E perp }\end{array}$ & $\begin{array}{l}7 \\
4 \\
4 \\
1\end{array}$ & $\begin{array}{l}2 \\
3 \\
4 \\
2 \\
3 \\
4 \\
2 \\
2 \\
3 \\
2 \\
2 \\
3\end{array}$ & $\mid$ & $\left.\right|_{1} ^{3.1}$ & $\begin{array}{l}3.33 \\
3.38 \\
3.58 \\
4.11 \\
4.25 \\
4.44 \\
3.49 \\
3.55 \\
3.64 \\
3.70 \\
4.01 \\
3.78\end{array}$ \\
\hline $\mathrm{H}-429$ & $\begin{array}{l}404 \\
405 \\
406 \\
434 \\
435 \\
436\end{array}$ & $\begin{array}{l}\text { Para } \\
\text { Para } \\
\text { Para } \\
\text { Perp } \\
\text { Perp } \\
\text { Perp }\end{array}$ & 4 & $\begin{array}{l}30 \\
30 \\
30 \\
30 \\
30 \\
40\end{array}$ & 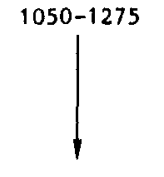 & $i$ & $\begin{array}{l}3.77 \\
3.67 \\
3.66 \\
4.70 \\
4.52 \\
4.37\end{array}$ \\
\hline$H-451$ & $\begin{array}{l}341 \\
342 \\
343 \\
466 \\
467 \\
468\end{array}$ & $\begin{array}{l}\text { C para } \\
\text { C para } \\
\text { C para } \\
\text { C perp } \\
\text { C perp } \\
\text { C perp }\end{array}$ & 5 & $\begin{array}{l}6 \\
6 \\
7 \\
6 \\
6 \\
7\end{array}$ & $\begin{array}{c}1390 \\
1\end{array}$ & $\left.\right|^{3.6}$ & $\begin{array}{l}3.49 \\
3.73 \\
3.69 \\
4.30 \\
4.37 \\
4.16\end{array}$ \\
\hline$H-429$ & $\begin{array}{l}141 \\
142 \\
143 \\
161 \\
162 \\
163\end{array}$ & $\begin{array}{l}\text { Para } \\
\text { Para } \\
\text { Para } \\
\text { Perp } \\
\text { Perp } \\
\text { Perp }\end{array}$ & $\begin{array}{l}5 \\
1\end{array}$ & $\begin{array}{l}16 \\
16 \\
17 \\
16 \\
16 \\
17\end{array}$ & $\left.\right|^{1370-1500}$ & 1 & $\begin{array}{l}3.58 \\
3.38 \\
3.05 \\
4.16 \\
4.07 \\
4.29\end{array}$ \\
\hline
\end{tabular}

${ }^{(a)} C$ - center, E - edge; para - parallel, perp - perpendicular. 
TABLE A-20

THERMAL CONDUCTIVITY OF H-327 GRAPHITE SPECIMENS IRRADIATED IN CAPSULE OG-1

\begin{tabular}{|c|c|c|c|c|c|c|c|c|c|c|}
\hline \multirow[b]{2}{*}{$\begin{array}{c}\text { Spec1men } \\
\text { No. }\end{array}$} & \multirow[b]{2}{*}{$\begin{array}{c}\log \\
\text { Location and } \\
\text { Orientation }(a)\end{array}$} & \multirow[b]{2}{*}{$\begin{array}{c}\text { Crucible } \\
\text { No. }\end{array}$} & \multirow[b]{2}{*}{$\begin{array}{c}\text { Mean } \\
\text { Irradiation } \\
\text { Temperature } \\
\left({ }^{\circ} \mathrm{C}\right)\end{array}$} & \multirow[b]{2}{*}{$\begin{array}{c}\text { Fluence } \times 10^{-21} \\
\left(\mathrm{n} / \mathrm{cm}^{2}\right) \\
(E>0.18 \mathrm{MeV})\end{array}$} & \multicolumn{6}{|c|}{ Thermal Conductivity $\left(\mathrm{cal} / \mathrm{cm}-\sec -{ }^{\circ} \mathrm{C}\right)$} \\
\hline & & & & & $22^{\circ} \mathrm{C}$ & $200^{\circ} \mathrm{C}$ & $400^{\circ} \mathrm{C}$ & $600^{\circ} \mathrm{C}$ & $800^{\circ} \mathrm{C}$ & $\begin{array}{l}\text { Irradiated } \\
\text { Temperature } \\
\text { (extrapolated) }\end{array}$ \\
\hline 1 & E perp & 1 & $600-625$ & 2.9 & 0.038 & 0.044 & 0.044 & & & 0.044 \\
\hline 2 & E perp & 1 & $600-625$ & 2.9 & 0.038 & 0.044 & 0.043 & & & 0.041 \\
\hline 13 & E perp & 1 & $600-625$ & 2.9 & 0.040 & - & - & & & - \\
\hline 81 & E para & 1 & $600-625$ & 2.9 & 0.059 & 0.066 & 0.070 & & & 0.063 \\
\hline 82 & E para & 1 & $600-625$ & 2.9 & 0.064 & 0.081 & 0.080 & & & 0.071 \\
\hline 43 & $E$ perp & 5 & $1225-1350$ & 9.9 & 0.133 & 0.159 & 0.143 & 0.127 & 0.112 & 0.085 \\
\hline 44 & $\mathrm{E}$ perp & 5 & $1225-1350$ & 9.9 & 0.131 & 0.136 & 0.118 & 0.105 & 0.093 & 0.078 \\
\hline 45 & E perp & 5 & $1225-1350$ & 9.9 & 0.149 & - & - & - & - & - \\
\hline 86 & E para & 5 & $1225-1350$ & 9.9 & 0.212 & 0.222 & 0.195 & 0.176 & 0.139 & 0.10 \\
\hline 87 & E para & 5 & $1225-1350$ & 9.9 & 0.198 & 0.219 & 0.203 & 0.170 & 0.144 & 0.10 \\
\hline 3 & E perp & 7 & $875-920$ & 5.1 & 0.0794 & 0.097 & 0.083 & 0.078 & 0.072 & 0.070 \\
\hline 4 & $E$ perp & 7 & $875-920$ & 5.1 & 0.072 & 0.076 & 0.071 & 0.066 & 0.058 & 0.055 \\
\hline 32 & $E$ perp & 7 & $875-920$ & 5.1 & 0.085 & - & - & - & - & - \\
\hline 83 & E para & 7 & $875-920$ & 5.1 & 0.095 & 0.094 & 0.083 & 0.081 & 0.077 & 0.075 \\
\hline 84 & E para & 7 & $875-920$ & 5.1 & 0.094 & 0.110 & 0.100 & 0.094 & 0.085 & 0.080 \\
\hline
\end{tabular}

${ }^{(a)} E$ - edge; para = parallel, perp = perpendicular. 
TABLE A-21

THERMAL CONDUCTIVITY OF II-451 GRAPUTTE SPECIMENS IRRADIATED IN CAPSULF OG-1

\begin{tabular}{|c|c|c|c|c|c|c|c|c|c|c|}
\hline \multirow[b]{2}{*}{$\begin{array}{l}\text { Speclmen } \\
\text { No. }\end{array}$} & \multirow[b]{2}{*}{ Orientation (a) } & \multirow[b]{2}{*}{$\begin{array}{c}\text { Cructble } \\
\text { No. }\end{array}$} & \multirow[b]{2}{*}{$\begin{array}{c}\quad \text { Mean } \\
\text { Irradiation } \\
\text { Temperature } \\
\left({ }^{\circ} \mathrm{C}\right)\end{array}$} & \multirow[b]{2}{*}{$\begin{array}{c}\text { Fluence } \times 10^{-21} \\
\left(11 / \mathrm{cm}^{2}\right) \\
(\mathrm{L}>0.18 \mathrm{MeV})\end{array}$} & \multicolumn{6}{|c|}{ The rmal Conduct 1 vity $\left(\mathrm{cd} 1 / \mathrm{cm}-\mathrm{gec}-{ }^{\circ} \mathrm{C}\right)$} \\
\hline & & & & & $22^{\circ} \mathrm{C}$ & $200^{\circ} \mathrm{C}$ & $400^{\circ} \mathrm{C}$ & $600^{\circ} \mathrm{C}$ & $800^{\circ} \mathrm{C}$ & $\begin{array}{l}\text { Irradiated } \\
\text { Temperature } \\
\text { (extrapolated) }\end{array}$ \\
\hline 221 & Perp & 1 & 600 & 2.2 & 0.085 & 0.081 & 0.082 & & & 0.080 \\
\hline 222 & Perp & & & & 0.078 & 0.083 & 0.080 & & & 0.077 \\
\hline 223 & perp & & & & 0.078 & 0.082 & 0.082 & & & 0.081 \\
\hline 224 & Perp & & & & 0.077 & - & - & & & - \\
\hline 225 & Perp & & & & 0.068 & - & - & & & - \\
\hline 226 & Perp & & & & 0.074 & - & - & & & - \\
\hline 227 & Perp & & & & 0.076 & - & - & & & - \\
\hline 228 & Perp & & & & 0.073 & - & - & & & - \\
\hline 201 & Para & & & & 0.079 & 0.083 & 0.080 & & & 0.075 \\
\hline 202 & Para & & & & 0.087 & 0.095 & 0.097 & & & 0.084 \\
\hline 203 & Para & & & & 0.083 & - & - & & & - \\
\hline 204 & Para & 1 & 1 & f & 0.083 & - & - & & & - \\
\hline 242 & Perp & 5 & 1340 & 3.6 & 0.195 & 0.175 & 0.164 & 0.143 & 0.123 & 0.09 \\
\hline 243 & Perp & 1 & & & 0.202 & 0.213 & 0.190 & 0.161 & 0.127 & 0.085 \\
\hline 244 & Perp & & & & 0.216 & 0.203 & 0.185 & 0.162 & 0.129 & 0.09 \\
\hline 245 & Perp & & & & 0.205 & - & - & - & - & - \\
\hline 246 & Perp & & & & 0.214 & - & - & - & - & - \\
\hline 247 & Perp & 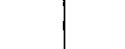 & & & 0.202 & - & - & - & - & - \\
\hline 248 & Perp & & & & 0.205 & - & - & - & - & - \\
\hline 249 & Perp & & & & 0.215 & - & - & - & - & - \\
\hline 210 & Para & & & & 0.193 & 0.216 & 0.188 & 0.158 & 0.142 & 0.10 \\
\hline 211 & Para & & & & 0.195 & 0.209 & 0.182 & 0.159 & 0.143 & 0.10 \\
\hline 212 & Para & & & & 0.195 & - & - & - & - & - \\
\hline 213 & Para & 1 & f & 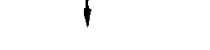 & 0.198 & - & - & - & - & - \\
\hline 231 & Perp & 7 & 920 & 3.1 & 0.104 & 0.131 & 0.112 & 0.101 & 0.092 & 0.090 \\
\hline 232 & Perp & & & & 0.097 & 0.111 & 0.105 & 0.092 & 0.085 & 0.082 \\
\hline 233 & Perp & & & & 0.109 & 0.113 & 0.100 & 0.092 & 0.082 & 0.080 \\
\hline 234 & Perp & & & & 0.110 & - & - & - & - & - \\
\hline 235 & Perp & & & & 0.114 & - & - & - & - & - \\
\hline 236 & Perp & & & & 0.099 & - & - & - & - & - \\
\hline 237 & Perp & & & & 0.104 & - & - & - & - & - \\
\hline 238 & Perp & & & & 0.085 & - & - & - & - & - \\
\hline 205 & Para & & & & 0.117 & 0.132 & 0.123 & 0.110 & 0.100 & 0.095 \\
\hline 206 & Para & & & & 0.118 & 0.130 & 0.117 & 0.107 & 0.096 & 0.092 \\
\hline 207 & Para & & & & 0.112 & - & - & - & - & - \\
\hline 208 & Para & 1 & $\phi$ & 1 & 0.113 & - & - & - & - & - \\
\hline
\end{tabular}

(a) Perp - perpendicular, Para - parallel. 
TABLE A-22

MEAN THERMAL CONDUCTIVITY OF GRAPHITE SPECIMENS IRRADIATED IN CAPSULE OG-1

\begin{tabular}{|c|c|c|c|c|c|c|}
\hline \multirow[b]{2}{*}{$\begin{array}{l}\text { Crucible } \\
\text { No. }\end{array}$} & \multirow{2}{*}{$\begin{array}{l}\quad \text { Mean } \\
\text { Irradiation } \\
\text { Temperature } \\
\quad\left({ }^{\circ} \mathrm{C}\right)\end{array}$} & \multirow{2}{*}{$\begin{array}{c}\text { Fluence } \times 10^{-21} \\
\left(\mathrm{n} / \mathrm{cm}^{2}\right) \\
(\mathrm{E}>0.18 \mathrm{MeV})\end{array}$} & \multirow[b]{2}{*}{$\begin{array}{l}\text { Graphite } \\
\text { Grade }\end{array}$} & \multirow[b]{2}{*}{ Orientation (a) } & \multicolumn{2}{|c|}{ Thermal Conductivity $\left(\mathrm{cal} / \mathrm{cm}-\mathrm{sec}-{ }^{\circ} \mathrm{C}\right)$} \\
\hline & & & & & $22^{\circ} \mathrm{C}$ & $\begin{array}{c}\text { At Irradiation Temperature } \\
\text { (extrapolated) }\end{array}$ \\
\hline 1 & $600-625$ & 2.9 & $\mathrm{H}-327$ & Perp & 0.039 & 0.043 \\
\hline 1 & $600-625$ & 2.9 & $\mathrm{H}-327$ & Para & 0.062 & 0.067 \\
\hline 1 & 600 & 2.2 & $\mathrm{H}-451$ & Perp & 0.076 & 0.079 \\
\hline 1 & 600 & 2.2 & $\mathrm{H}-451$ & Para & 0.083 & 0.080 \\
\hline 5 & $1225-1350$ & 9.9 & $\mathrm{H}-327$ & Perp & 0.137 & 0.082 \\
\hline 5 & $1225-1350$ & 9.9 & $\mathrm{H}-327$ & Para & 0.220 & 0.10 \\
\hline 5 & 1350 & 3.6 & $H-451$ & Perp & 0.207 & 0.09 \\
\hline 5 & 1350 & 3.6 & $\mathrm{H}-451$ & Para & 0.195 & 0.10 \\
\hline 7 & $875-920$ & 5.1 & $\mathrm{H}-327$ & Perp & 0.079 & 0.063 \\
\hline 7 & $875-920$ & 5.1 & $\mathrm{H}-327$ & Para & 0.095 & 0.078 \\
\hline 7 & 920 & 3.1 & $\mathrm{H}-451$ & Perp & 0.102 & 0.084 \\
\hline 7 & 920 & 3.1 & $\mathrm{H}-451$ & Para & 0.115 & 0.094 \\
\hline
\end{tabular}

${ }^{(a)}$ Perp $=$ perpendicular, Para $=$ parallel. 
TABLE A-23

TENS ILE TESTS ON H-327 GRAPHITE IRRADIATED IN OG-1 CAPSLLE

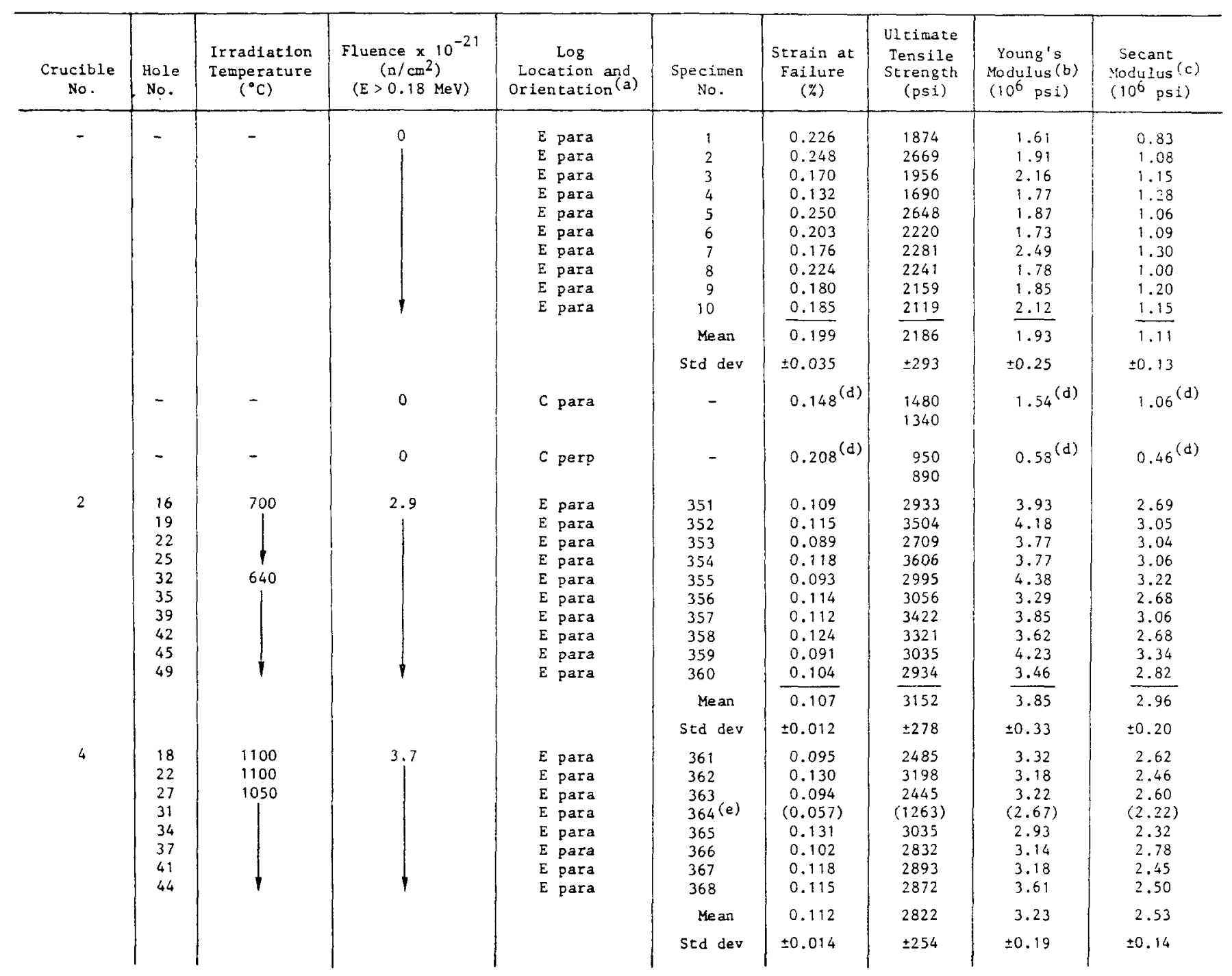


TABLE A-23 (Cont1nued)

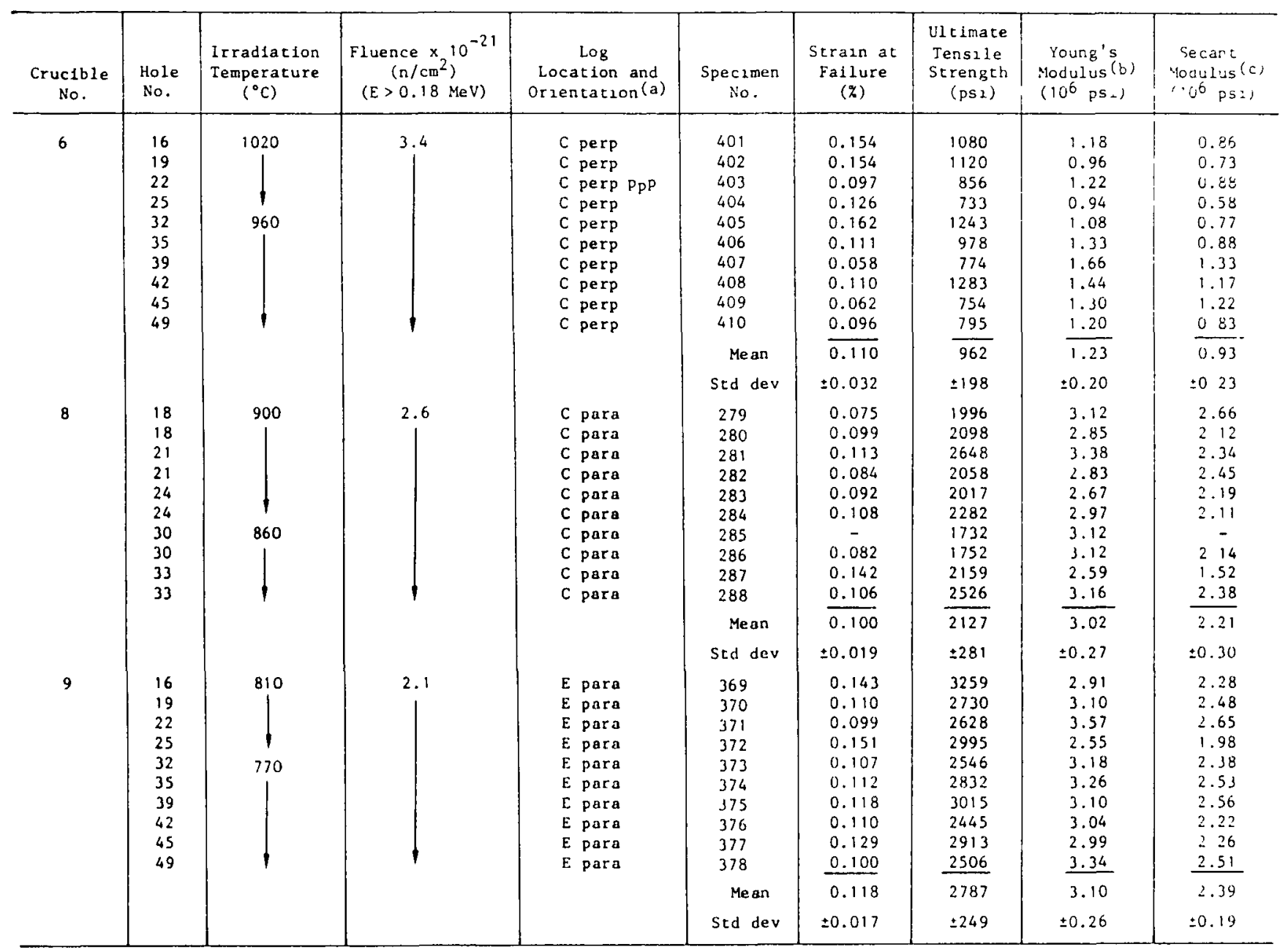

${ }^{(a)}$ E - edge, C - center, para - parallel, perp - perpendicular.

(b) 100-1000 psi (parallel samples) or 100-600 psi (perpendicular samples) after preloading to 1000 psi (parallel samples) or 600 psi (perpendicular samples), unloading sample, and reloading.

(c) Ultmate tenstle strength divided by fracture strain.

(d) Average values.

(e) Sample contained flaw; excluded from averages. 
TABLE A-24

TENSILE TESTS ON H-451 GRAPHITE IRRADIATED IN OG-1 CAPSULF

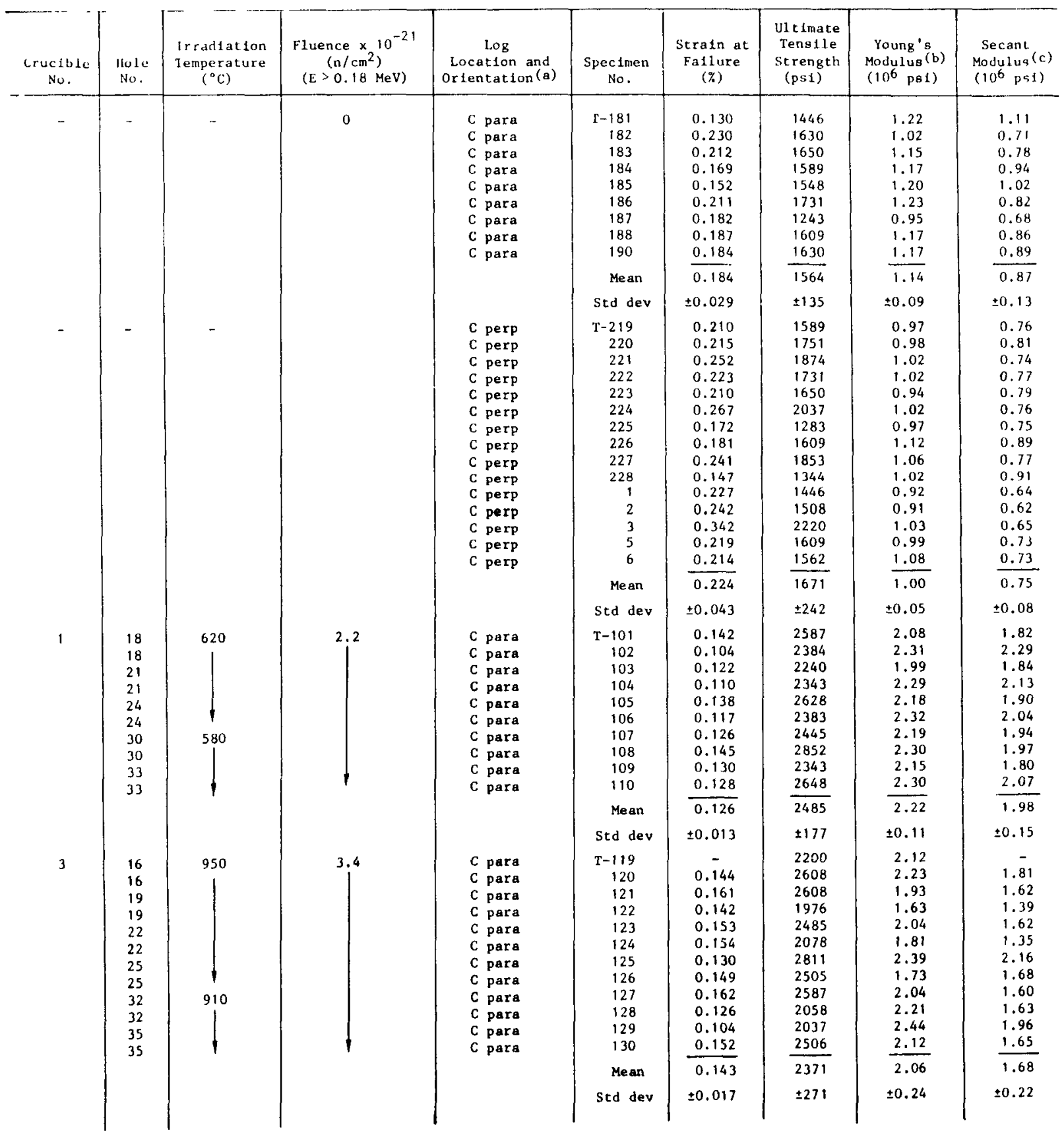


TABLE A-24 (Continued)

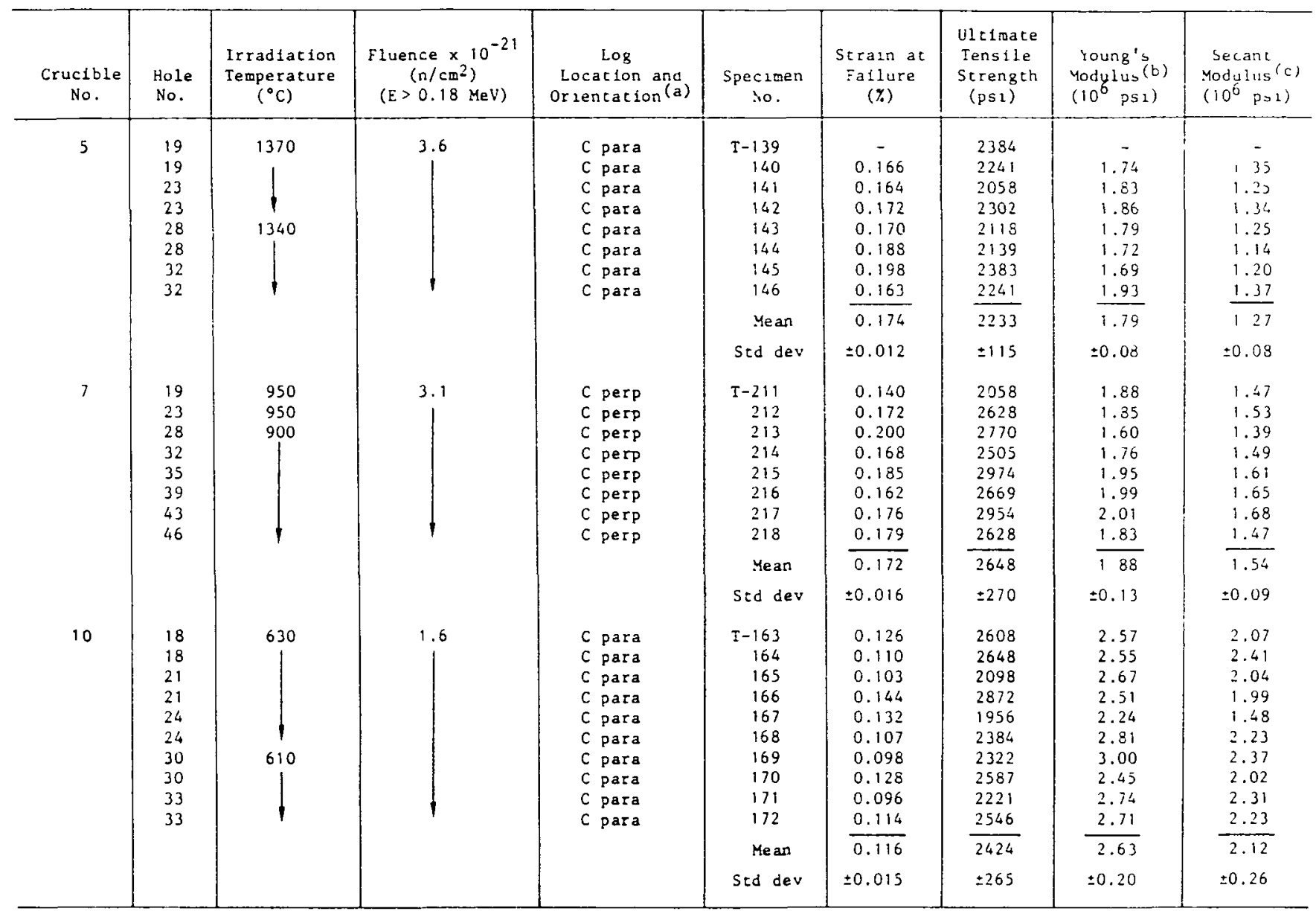

${ }^{(a)} \mathrm{C}=$ center, E - edge; para - parallel, perp = perpendicular.

(b) 100-1000 psi, after preloading to $1000 \mathrm{psi}$, unloading sample, and reloading.

(c) U1timate tensile strength divided by fracture strain. 